\title{
Processing, Valorization and Application of Bio-Waste Derived Compounds from Potato, Tomato, Olive and Cereals: A Review
}

\author{
Caroline Fritsch ${ }^{1}$, Andreas Staebler ${ }^{1, *}$, Anton Happel ${ }^{2}$, Miguel Angel Cubero Márquez ${ }^{3}$ (D), \\ Ingrid Aguiló-Aguayo ${ }^{4}$, Maribel Abadias ${ }^{4}$, Miriam Gallur ${ }^{5}$, Ilaria Maria Cigognini ${ }^{6}$, \\ Angela Montanari ${ }^{6}$ (D), Maria Jose López ${ }^{7}$ (D), Francisca Suárez-Estrella ${ }^{7}$, Nigel Brunton ${ }^{8}$, \\ Elisa Luengo ${ }^{8}$, Laura Sisti ${ }^{9}$, Maura Ferri ${ }^{9}$ and Gianluca Belotti ${ }^{10}$ \\ 1 Fraunhofer Institute for Process Engineering and Packaging IVV, Giggenhauser Straße, 35, 85354 Freising, \\ Germany; caroline.fritsch@ivv.fraunhofer.de \\ 2 Bioprocess Pilot Facility B.V. (BPF), Postbus, 198, 2600 AD Delft, The Netherlands; Anton.Happel@bpf.eu \\ 3 Indulleida S.A., Carretera N-230, Km. 12, 25125 Alguaire, Spain; macubero@indulleida.com \\ 4 IRTA Fruitcentre, Parc Científic i Tecnològic Agroalimentari, 25003 Lleida, Spain; \\ ingrid.aguilo@irta.cat (I.A.-A.); isabel.abadias@irta.cat (M.A.) \\ 5 Instituto Tecnológico del Embalaje, Transporte y Logística (ITENE), Albert Einstein, 1, Paterna, \\ 46980 Valencia, Spain; mgallur@itene.com \\ 6 Experimental Station for the Food Preserving Industry (SSICA), Viale Tanara 31/A, 43121 Parma, Italy; \\ IlariaMaria.Cigognini.cococo@ssica.it (I.M.C.); angela.montanari@ssica.it (A.M.) \\ 7 Department of Biology and Geology, Carretera Sacramento, University of Almeria, La Cañada, \\ 04120 Almeria, Spain; mllopez@ual.es (M.J.L.); fsuarez@ual.es (F.S.-E.) \\ 8 UCD Agriculture and Food Science Centre, University College Dublin, Dublin 4, Ireland; \\ nigel.brunton@ucd.ie (N.B.); elisa.luengo-maranillo@ucd.ie (E.L.) \\ 9 Department of Civil, Chemical, Environmental, and Materials Engineering, University of Bologna, \\ Via Terracini, 28, 40131 Bologna, Italy; laura.sisti@unibo.it (L.S.); maura.ferri@unibo.it (M.F.) \\ 10 Innovacio i Recerca Industrial i Sostenible S.L. (IRIS), Avda. Carl Friedrich Gauss 11, 08860 Castelldefels, \\ Spain; gianluca.belotti@iris.cat \\ * Correspondence: andreas.staebler@ivv.fraunhofer.de, Tel.: +49-8161-491411
}

Received: 18 July 2017; Accepted: 17 August 2017; Published: 22 August 2017

\begin{abstract}
The vast and ever-growing amount of agricultural and food wastes has become a major concern throughout the whole world. Therefore, strategies for their processing and value-added reuse are needed to enable a sustainable utilization of feedstocks and reduce the environmental burden. By-products of potato, tomato, cereals and olive arise in significant amounts in European countries and are consequently of high relevance. Due to their composition with various beneficial ingredients, the waste products can be valorized by different techniques leading to economic and environmental advantages. This paper focuses on the waste generation during industrial processing of potato, tomato, cereals and olives within the European Union and reviews state-of-the-art technologies for their valorization. Furthermore, current applications, future perspectives and challenges are discussed.
\end{abstract}

Keywords: agricultural waste; food waste; valorization technologies; food additives; packaging materials; bio-fertilizers; potato; tomato; olive; cereals

\section{Introduction}

Within the European Union, approximately 700 million tons of agricultural wastes are generated annually [1]. The total food loss produced by households, food industry, restaurants or during the distribution chain without agricultural food waste (which arises due to damage or spillage during 
harvest) accounts for about 89 billion tons in 2006 within the EU-27 [2]. On a global level, approximately one third of the produced food is wasted every year throughout the whole value chain from farmers to consumers. According to FAO, this is about 1.3 billion tons per year [3]. This causes both environmental and economic problems. Therefore, the European Union promotes several programs like the integrated product policy, the resource efficiency flagship initiative and the bio-economy communication to prevent agricultural and food loss [4-7].

Waste and by-products generated from potato, tomato, cereals and olive processing are of high relevance as they arise in significant amounts in the European market. In particular, the European Union is the world largest producer of wheat (143 million tons), oat ( 7.8 million tons) and olive oil (2.1 million tons) [8]. Furthermore, in 2014 the EU produced 16.9 million tons of tomatoes and as well as about 60.7 million tons of potatoes [9]. During harvesting and processing of these crops, wastes and by-products are generated. These wastes can potentially be upgraded in other production processes and may be used as resources for bioactive compounds such as carotenoids, phenolic compounds, essential oils or $\beta$-glucans [10-14]. The extracted compounds have a potential use as functional ingredients or additives in the food industry due to their health properties, antioxidant and antimicrobial activities as well as their ability to work as a natural food colorant [15-20]. Moreover, tissues from by-products contain varying concentrations of flavor volatiles that may be recovered and used in the food and beverage industry [21,22]. Other valuable ingredients might be the content in dietary fibers including polysaccharides and lignin or proteins that can be used as functional food ingredient increasing the nutritional value and providing useful properties in food [23-25]. Likewise, different compounds of food waste have antioxidant or antimicrobial effects which can be used for active packaging or edible coating to extend the shelf life of food products. For example phenolic compounds such as hydroxytyrosols contained in olive waste or wheat bran have potential antioxidant properties. Furthermore, oat husk residues from cereal processing can be used as a reinforcing agent in the production of bio-composites for packaging applications [26]. Currently, the applications of waste streams include the use as plant fertilizer, composting and biogas material or animal feed. Otherwise they are incinerated or landfilled. Consequently, they do not generate value for the farmers but lead to billion euros lost in waste management and cause an environmental burden $[27,28]$.

Due to various application possibilities and its economic impact, the valorization of food wastes has attracted increasing attention. Furthermore, the global food production and thereby the amount of food waste is expected to rise, ensuring the increased attention [4]. This review demonstrates the potential of four selected feedstock wastes (potato, tomato, wheat and olive) as food additives, agricultural materials, packaging materials and bio-fertilizers. Moreover, the state-of-the-art technologies and applications are presented focusing on mainstream sectors, e.g., food, nutraceutical and pharmaceutical industry. By this means, a sustainable utilization of agricultural commodities is facilitated. In the following sections each chapter focuses on one feedstock waste, its characteristics and the most important waste valorization techniques.

\section{Valorization of Potato Residues}

\subsection{Extraction of Phenolic Compounds from Peels}

Phenolic compounds can be classified as secondary plant metabolites. This term describes substances that are formed by plants during their secondary metabolism. They are thus not essential for the survival of plants. However, many of them are bioactive and phenolic substances can have antioxidant, antimicrobial, anticarcinogenic and several other beneficial health effects [29-32]. Whilst whole potatoes are a relatively poor source of polyphenols many studies have demonstrated that these secondary metabolites are enriched in the peel of most cultivars. This is not surprising given their role in the tuber as an allelochemical to prevent attack by fungi and other microbes. This fact coupled with the abundance of potato peel as a by-product of potato processing has meant that a large number of studies on the extraction of phenolic compounds from potato peel have been published. In fact, the 
topic has formed part of a number of review articles dedicated to the valorization of agro-industrial products particularly the work of Balasundram, et al. [33] and Wijngaard, et al. [34] and the therein cited articles.

This section will attempt to summarize and evaluate recent advances and cover both, conventional methods of extraction such as solid/ liquid extraction and novel assisted methods. Table 1 presents a selection of studies carried out in the last decade on extraction of phenolics from potato peels and details on cultivars, optimal extraction and maximum yields. At the outset it should be stated that a wide range of polyphenol levels in potato peel even for optimal extraction conditions have been reported. For example, levels ranging from 112 to $431 \mathrm{mg} / 100 \mathrm{~g}$ have been published as yield obtained by applying optimal conditions through various techniques in the past ten years. This is perhaps not surprising given the range of cultivars that have been examined and the lack of standardized post processing conditions and analytical methods. By far the most common method of measuring extraction efficiency is the Folin-Ciocalteu reagent method (also known as the FCR assay) however, some studies have reported on the levels of individual phenolic compounds. In most cases studies reported that ferulic, chlorogenic and caffeic acid are the most abundant phenolic acids in varieties used for industrial processing although a wider range such as gallic acid, protocatechuic acid, coumaric acid, syringic acid, vanillic acid and p-hydroxy benzoic acid have been determined in less common cultivars [35]. The authors reported levels of chlorogenic acid ranging from $0.86-2.79 \mathrm{mg} / \mathrm{g}$ in dried peel powder of six potatoes varieties growing in Ontario. Chlorogenic acid and caffeic acid were found to be the predominant phenolic acids present in the varieties they examined. In contrast, Wijngaard, Ballay and Brunton [34] detected that caffeic acid was the predominant phenolic compound in extracts obtained by pressurized liquid and solid liquid extraction (SLE) from peel samples of the Lady Claire variety. The maximum level reported was $651 \mu \mathrm{g}$ caffeic acid/g dry matter in SLE extracts. However, the authors did not analyze chlorogenic acid in their extracts. This is surprising as it usually is the most common phenolic compound in potato peels. However, when stored at room temperature or exposed to light, chlorogenic acid can be converted into caffeic acid and quinic acid [36]. Therefore, if researchers are interested in adding value to potato peel waste by isolating chlorogenic acid, the instability of this compound should be taken into account. In addition, when attempting to interpret results from the reported studies, the method used to generate the peel should be considered. In many cases, peels were prepared manually, which does not reflect the abrasion methods currently used during industrial scale peeling process of potatoes.

Simple solid liquid extraction is still the most common method used in studies aimed at extraction of phenolic compounds from potato peels (used in three of eight studies in Table 1). Whilst this method may have some drawbacks particularly with regard to high energy and solvent use, the equipment used is simple and does not require a large capital investment. These are distinct advantages for researchers and industry stakeholder who are not willing to commit a large investment and do not have the expertise to maximize the gains from the novel technology aided approaches described in more detail below. In common with other food by-products, phenolic compounds are best extracted from potato peels with hydro-ethanolic solvents at ethanol concentrations ranging from $70-80 \%$. One major advantage of ethanol as extracting solvent is its status as a food friendly solvent. However, some studies have used methanol due to its much lower price compared to ethanol. It would be expected that methanol behaves in the same manner as ethanol however it cannot be used as solvent for food due to its reported toxicity [37]. In some cases, water has been used as extracting solvent. Water is the ideal solvent for food use as it is both food friendly and inexpensive. However, it will only extract water soluble phenolics and the predominant species mentioned above are only sparingly soluble in water. For example, caffeic acid is slightly soluble in cold water but completely soluble in hot water [38].

Recently, many authors have recognized the need to develop more sustainable energy efficient methods for recovering valuable compounds from food by-products. This has resulted in a move towards the use of novel technology aided approaches to achieve this goal. Most of these techniques 
aid extraction of the target compound by facilitating the release of intracellular compounds such as phenolics by breaking cell envelopes. This allows their isolation in the subsequent extraction step with less energy. Both, pulsed electric field (PEF) [39] and ultrasound assisted extraction (UAE) [40] operate by this principle and have been successfully applied for the extraction of phenolics from potato peels using water as solvent. Pereira, et al. [41] applied a novel technological approach, namely ohmic heating to allow the use of water as solvent for the recovery of phenolics from potato peels. Ohmic heating applies a constant electric field, in contrast to a pulsed electric field and is more commonly used as a novel method for heating foods. It can also be used to electroporate cells whilst simultaneously heating and thus facilitating increased mass transfer into the extracting solvent. As a result of the fears that it may degrade thermally labile compounds ohmic heating is less commonly reported on as an extraction technique than PEF or ultrasound. However, most phenolic compounds are reasonably heat stable and thus ohmic heating may warrant more investigation with regard to the extraction of phenolics from potato peel. Further emphasizing the increasing use of water as a solvent, Singh and Saldana [42] examined the application of subcritical water (i.e., water at high pressures and temperatures) to extract polyphenols from potato peels. They reported good recovery rates for phenolic compounds $\left(81.83 \mathrm{mg} / 100\right.$ at $180^{\circ} \mathrm{C}$ for $\left.30 \mathrm{~min}\right)$ as compared to $3 \mathrm{~h}$ extraction with methanol.

In summary, the ideal extraction method for recovering polyphenols from potato peels would have the following characteristics: low energy consumption, little capital investment, water as a solvent, high yield and an easy integration into existing processing lines. Unfortunately none of the methods discussed here fulfill all of these criteria. Therefore, potato processors must seek the method that best matches their priorities, i.e., extraction yields, sustainability or high through-put.

Since potato peel is a valuable source for phenolic acids such as chlorogenic, caffeic, gallic and protocatechuic acids, several applications using their antioxidant activity have been described [19,43,44]. According to Viscidi, et al. [45] phenolics such as catechin, chlorogenic acid and ferulic acid were mixed with other ingredients prior to extrusion for the manufacturing of rolled oats leading to products more resistant to oxidation. Although processing resulted in a $24-26 \%$ reduction of the amount of phenolics added, the final products had a higher phenolic content in comparison to the conventional ones.

Table 1. Selection of recent studies aimed at the extraction of phenolics from potato peels detailing optimal extraction conditions, maximum yields, method and cultivar used.

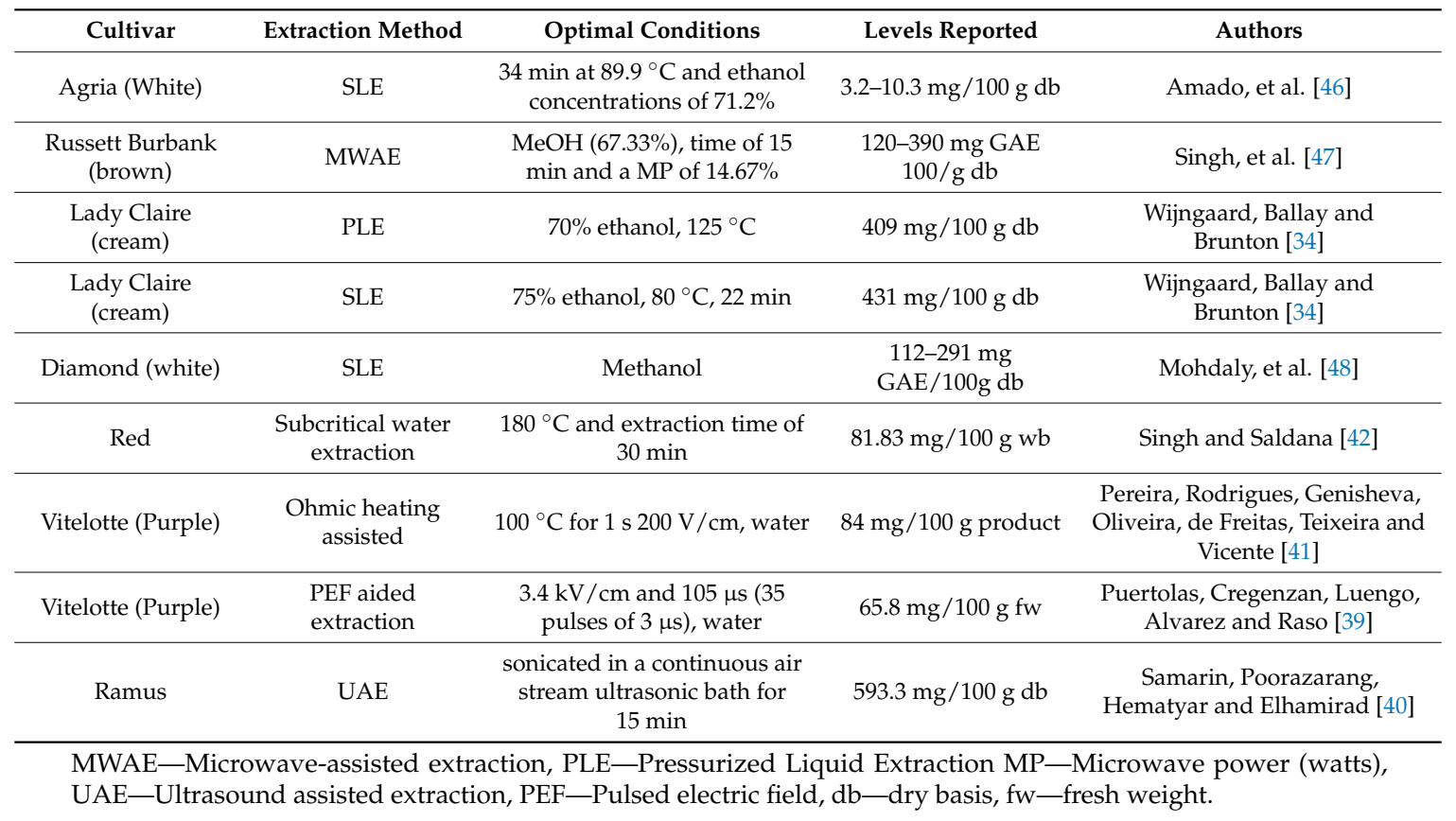




\subsection{Liquefaction of Potato Peels}

Another possibility to valorize the continuously increasing amount of potato peel wastes is the use as substrate for different processes. Since these wastes are rich in starch they are a valuable feedstock for ethanol production [49,50]. However, prior fermentation or other processing steps the peels have to be hydrolyzed into fermentable sugars which can be further converted into valuable compounds. This can be achieved either by acids or by enzymes. For an acidic treatment, a mixture of 2-ethylhexanol and diethylene glycol with $3 \%$ of p-Toluenesulfonic acid at $160{ }^{\circ} \mathrm{C}$ was used [51,52]. This thermochemical process resulted in high yields of bio-oil (up to 93\%). However, due to their biodegradability, high efficiency and capability to react under mild conditions, enzymes are more advantageous. Moreover, an enzymatic hydrolysis does not require a neutralization step like the acidic treatment [53]. Commonly, alpha-amylase from Bacillus licheniformis or from recombinant strains of Escherichia coli or Bacillus subtilis is applied to liquefy the slurries. Depending on the used enzyme, reaction conditions of $55-85{ }^{\circ} \mathrm{C}$ and $\mathrm{pH}$ 5.5-6.0 are applied, exemplary for Ternamyl ${ }^{\circledR}$ and Liquozyme ${ }^{\circledR}[49,54]$. Several enzyme manufacturers (biocatalysts, DSM, etc) are actually offering plenty more enzymes that can be used to downgrade cellulose, hemicelluloses and pectins. By this means a liquefied product can be obtained which can be used to recover chemicals from vegetable origin. Possible applications of produced ethanol are biofuel or biopolyols [55]. Another possible liquefaction technology is the hydrothermal liquefaction in subcritical water. This procedure results in high values of the ionic product and can be used for different kinds of biomass. This is due to the fact that the density and dielectric constant of water decreases while the hydrocarbon solubility increases [56-59]. Li, et al. [60] applied this process to convert starch of rice, potato and sweet potato into reducing sugars which can be used for fermentation and ethanol production.

\subsection{Aroma Extraction from Liquefied Potato Peels}

Aroma extraction has been developed by human kind since ancient ages [61] and it is still a possible way to make use of waste materials. Current methods are conducted in an industrial approach. To avoid great losses of the natural aroma that comes from vegetables, mild conditions (i.e., temperature) are advisable. One of the most used methods is the alcoholic extraction, which is applied to recover several substances from their matrices. The raw material is blended with a mixture of water and alcohol, commonly between 50 and $90 \%$ alcohol [62]. The extraction time can vary from 30 minutes to several days. The blend is filtered and the liquid can be directly used or it can be distilled to separate more concentrated compounds.

Other interesting volatiles can be extracted by centrifugation. Particularly, organic volatiles that are mainly hydrophobic can be recovered by this process. When they reach a certain concentration, they can be separated from the water matrix. For example, those products are called 'cold pressed essential oils'. Essential oils can also be recovered using strong organic solvents, such as hexane or ethyl acetate $[63,64]$. Moreover, biotechnological approaches are used to create more volatiles in the product before they are recovered, as it is well known that aroma compounds are produced in secondary paths of vegetable metabolism. Enhancing some pathways of the metabolism, e.g., by addition of external enzymes such as beta-glucosidases, can lead to the production of more volatiles [63]. An interesting technology to recover volatiles in mild conditions is the Spinning Cone Colum [65]. The volatiles are extracted by using steam as an extractant at low temperatures under vacuum conditions. A system of rotary and stationary plates is applied to generate centrifugal force which causes the feed material to flow as a thin film on the surface of the cone. By introducing stripping steam the volatile compounds are separated of the liquids and slurries [65].

Buttery, et al. [66] used a vacuum steam distillation continuous extraction with hexane $(3 \mathrm{~h})$ for recovering volatile compounds from baked potatoes. They analyzed a markedly greater ratio of pyrazines to aldehydes in the peels than in potato pulp. Furthermore, Oruna-Concha, et al. [21] examined baked potatoes for their volatile compounds and identified sugar degradation and Maillard reaction as the main sources of volatiles in potato peels. In this study, pentane and diethyl ether 
$(9: 1 v / v)$ were used as solvents for the extraction of $2 \mathrm{~h}$. According to their results, pyrazines amounts up to $73 \%$ with 2,5- and/or 2,6-dimethylpyrazine being the most common compound in the peels. These substances can be further used and upgrade potato peel wastes.

\subsection{Ultrasound Assisted Extraction of Toxic Compounds From Potato Residues}

\subsubsection{Alkaloids Content in Potatoes}

There are more than 4000 varieties of native potatoes [67] which differ in characteristics such as the shape of the tuber or the color, but generally they have high starch content and are rich in minerals (especially potassium, magnesium and iron) and vitamins (B1, B2, B6, and C) [68]. Even if the tubers are a valuable source of nutritional elements, potatoes are also rich in steroidal alkaloids, a class of secondary metabolites commonly found in the plants of Solanaceae family. Steroidal alkaloids are associated with defense against bacterial [69], fungal [70] and insect attacks [71]. These compounds are toxic and their adverse effects on human health are typically associated with symptoms such as colic pain, diarrhea, gastroenteritis, vomiting, fever, low blood pressure, rapid pulse and neurological disorders [72,73].

The most abundant steroidal alkaloids in potatoes are $\alpha$-solanine and $\alpha$-chaconine. Both derived from solanidine by the linkage of two different trisaccharides to the hydroxyl group at carbon C-3 (Figure 1). In particular, $\alpha$-solanine contains a glycosidic chain that is built up of glucose, galactose and rhamnose units. $\alpha$-chaconine has a different glycosidic chain which is made of two glucose units and one of rhamnose [74,75]. The composition of the glycosidic chains is supposed to be related to the cytotoxic effects of the two alkaloids, even if the cytotoxicity mechanism has not been fully clarified yet $[76,77]$. The two toxins appear to inhibit the human enzyme acetyl cholinesterase [78], the calcium transport [79], the transport through cellular membranes $[80,81]$ and even at low concentrations (micro molar) the compounds may be able to harm nerve cells [82]. In vitro experiments revealed that $\alpha$-solanine and particularly $\alpha$-chaconine are effective cytotoxins (IC50 $=4.1 \mu \mathrm{M}$ ) by rapidly inducing cell lysis $[83,84]$.

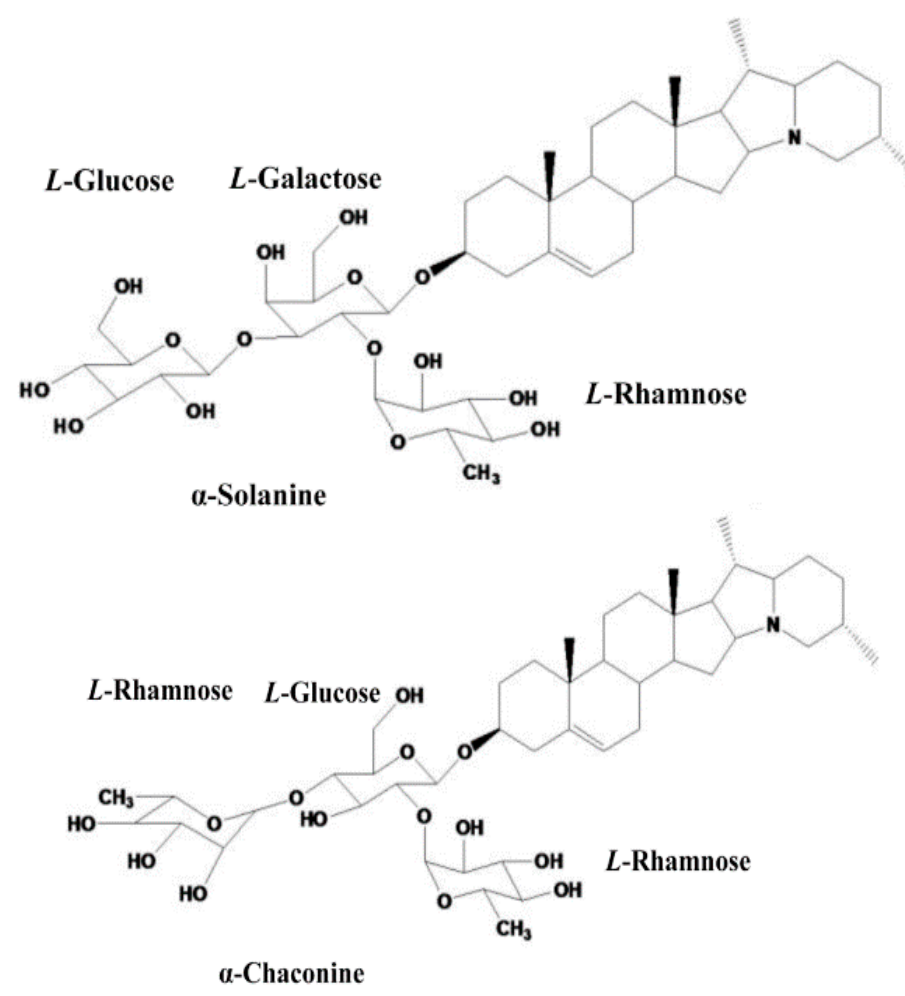

Figure 1. Structures of $\alpha$-solanine and $\alpha$-chaconine. 
Toxins accumulation in potatoes occurs mainly in the peel as it represents the first barrier against pathogenic attacks [76]. This layer is also the main waste derived by the potatoes industrial processing, which results in between 70,000 and 140,000 tons of peels worldwide annually [85]. Even if this massive amount of waste could be a suitable feedstock for added value conversions, currently it is only used for animal feed or disposed causing environmental concerns. Potato peels quickly undergo microbial spoilage [68] and their use into valuable application is prevented by technical and economical limitations including alkaloids content. Therefore, an extraction of these toxic components will enhance the valorization possibilities of potato peels.

\subsubsection{Ultrasounds Assisted Extraction of Alkaloids from Potato Peel}

In addition to conventional extraction methods, several intensification techniques for the extraction of secondary metabolites from plant tissues have been proposed and tested also to remove alkaloids from potato peels [86-88]. Among these, ultrasounds-assisted extraction (UAE) is one of the most promising solutions, combining acoustic energy and solvent to extract target compounds from different plant matrices, resulting in an inexpensive, rapid and environmentally friendly process [89-91]. Similar to other secondary metabolites, the extraction of alkaloids, indeed, is hindered by the structure of the plant cell wall that retains these compounds from the solvent.

Ultrasounds generate acoustic waves that propagate into the liquid media causing alternating compression and expansion cycles. If the ultrasounds intensity is high enough, the expansion cycle can create cavities or bubbles in the liquid that suddenly collapse releasing high amount of energy. This phenomenon is called cavitation. The implosion of cavitation bubble can locally reaches $5000 \mathrm{~K}$ and $200 \mathrm{~atm}$ and generates sharp liquid jets of up $280 \mathrm{~m} / \mathrm{s}$ velocity [92]. The mechanical shear force caused by these jets breaks the plant cell wall (following different mechanism such as fragmentation, erosion, capillarity, detexturation, and sonoporation). This allows an enhanced penetration of solvent into the sample matrix. Thereby, the contact area between the solid and liquid phase is increased and thus a higher mass transfer of the target compound toward the solvent occurs [93-95]. Moreover, ultrasounds can improve the extraction yield by increasing the net hydrophobic character of the extraction medium (when the target molecule is non-polar) and reducing the particle size [96].

A number of parameters can be adjusted to optimize extraction of target compounds using ultrasounds, including extraction time and temperature, ultrasound amplitude and extracting solvent [92]. However, the outcome depends intrinsically on the nature of the matrix and the geometry of the system. Therefore, the main process variables can be grouped in physical and medium related parameters. In the first group the characteristics of the mechanic waves such as frequency, wavelength and amplitude are included. Likewise, the power input, reactor design and shape of the probe can influence the process [97]. The medium related parameters include solvent chemo-physical properties, the reaction temperature, the presence of dissolved gasses and external pressure and the matrix properties. A comprehensive review on the parameters affecting UAE and its mechanism has been recently published by Chemat, Rombaut, Sicaire, Meullemiestre, Fabiano-Tixier and Abert-Vian [92].

Regarding the up-scaling procedure, as reminded by Vinatoru [98], UAE is a very complex process and what is observed in a volume of some milliliters (typical for lab scale experiments) is not indicative of a volume of one liter and absolutely different than a pilot scale reaction. Therefore, even if the application of UAE at laboratory scale is widely published, a minor number of applications have been commercially introduced. The main obstacle for an implementation of ultrasound in industrial processes might be the structure and development of potent generators and reactor which are capable of large scale procedures [99]. Nevertheless, UAE is already adopted in industry, for example in the food sector. It is used for extraction, cutting or degassing, but also for enzyme inactivation or the sterilization of equipment [92]. 


\subsection{Production of Food Microorganisms Using Potato Pulp and Process Water}

Literature about the utilization of agro-industrial wastes to produce beneficial microorganisms like biocontrol agents, baker's yeast, brewer's yeast or probiotic cultures is scarcely. Published references deal with the use of these wastes to produce secondary metabolites (e.g., enzymes, organic acids) and single cell protein (SCP). SCP or microbial protein is the dried form of various microorganisms, such as bacteria, fungi and algae. SCP is used as animal feed and as supplemental feed-stuff material. Several agro-industrial wastes have been utilized as economic substrates to produce SCP, including potato residues and oil mill wastewater [100-102]. Other wastes like fruit pomaces, whey, molasses and lignocellulosic biomass have also been widely studied [103-106].

The yeast Saccharomyces (S.) cerevisiae is used for several food applications like brewer's and baker's yeast, wine production, biotechnology processes (e.g., enzyme, bioethanol, acid production), and also as SCP. S. cerevisiae is specialized for the metabolization of glucose, fructose and sucrose. S. cerevisiae cannot be directly applied to convert cellulose. Therefore, pretreatments are required to release glucose from cellulose-rich wastes [107]. The wild-type of S. cerevisiae is not able to metabolize xylose and arabinose, which are contained in lignocellulosic hydrolysates and it is incapable of degrading starch. Moreover, this yeast is sensitive to furfural and hydroxymethylfurfural which are formed during the thermal pretreatment of lignocellulose [108].

Potato wastes are biomasses rich in starch and lignocellulosic constituents. Starch is the storage form of carbohydrates in plants. It consists of several glucose units linked by $\alpha-1,4$ linkages and joined by $\alpha-1,6$ linkages. S. cerevisiae, like many other microorganisms, is not able to metabolize starch due to the absence of starch degrading enzymes such as $\alpha$-amylase (cleaving $\alpha$-1,4-glycosidic bonds), $\beta$-amylase (separating maltose units from starch), isoamylase and pullulanase (hydrolyzing $\alpha-1,6$-glycosidic bonds) or glucoamylase (cleaving glucose units from the non-reducing part of starch). Therefore, it is required either to add starch-degrading enzymes prior fermentation with S. cerevisiae or to use a recombinant strain that express these enzymes in order to metabolize starch $[109,110]$.

Potato wastes and wastewaters have been utilized to produce SCP from various microorganisms and also for the production of secondary metabolites. They have been used alone, enriched with other wastes or supplemented with chemically defined culture media or chemicals. Potato peel has been applied for the production of S. cerevisiae biomass [111]. For this peels were dried, ground, sieved and pretreated to convert cellulose into a more available sugar. Similarly, potato wastewaters from the starch production have been used for the production of Bacillus thuringiensis [112]. Starchy wastewater from potato chip factory demonstrated to be as good as synthetic defined medium for the production of the probiotic strain Streptomyces [113]. Chemically defined potato starch has been found to be a good nutrient source for the growth of the yeast Schanniomyces alluvius, equally [114].

There are several studies on the production of microbial secondary metabolites using potato wastes and wastewaters. For example, potato wastes from the potato chip processing (rotten and substandard potato tubers, potato peel and substandard potato chips) were applied for the production of chitosan by fermentation with Rhizopus oryzae [115]. Enriched potato wastes from potato flakes processing (without pretreatment) were also found to be a good nutrient source for the production of glucoamylase by several strains of Aspergillus niger [116]. Pagana, et al. [117] produced lactic acid using different acid lactic bacteria and sweet potato wastes (peel and water with residual flesh) enriched with sugars. For this purpose, a previous enzyme hydrolysis of the waste was carried out. Further utilization of potato substrates (laboratory simulated wastes) was the production of a biosurfactant by Bacillus subtilis [118]. In this case, potato wastes were not hydrolyzed.

\subsection{Protein Extraction from Potato Fruit Juice}

During processing of potatoes $5-12 \mathrm{~m}^{3}$ of potato fruit juice accumulates per ton $[119,120]$. This leads to more than two million tons of potato fruit juice in the European Union per year [121].

The fruit juice is separated by single- or multi-stage decanters of the washed and rasped potatoes. This aqueous by-product with approximately $5 \%$ dry matter mainly contains proteins $(\sim 35 \%$ of $\mathrm{dm})$, 
sugar $(\sim 35 \%$ of $\mathrm{dm})$, minerals $(\sim 20 \%$ of $\mathrm{dm})$, organic acids $(\sim 4 \%$ of $\mathrm{dm})$ and other components [122]. The maximum concentration of toxic glycoalkaloids ( $\alpha$-solanin, $\alpha$-chaconin) amounts up to $100 \mathrm{ppm}$ which is far below the permitted level in food products [123,124]. The potato protein predominantly consists of patatin, protease inhibitors, high-molecular-weight proteins and is rich in in lysine $(7.18 \%)$ and methionine $(1.06 \%)$ [125,126]. As these fractions have high nutritional quality, antioxidant potential and valuable functional properties, its recovery is highly desired especially for use in human nutrition [127-129]. Due to the scarcity of protein-rich food this valuable by-product should be re-used and thereby improve protein sustenance and the sustainable use of potatoes.

So far, the potato fruit juice is mostly applied as fertilizer by spreading the juice on the fields. However, in winter months this procedure cannot be done due to a reduced biological activity of soil. Therefore, high amounts of wastewater arise. Due to environmental regulations in the European Union, some countries investigated several methods to purify this waste stream and to recover valuable ingredients [121]. Commonly, proteins are extracted through precipitation by steam injection and $\mathrm{pH}$ adjustment leading to protein concentrates with yields about $50 \%$. Such a process was developed by Westfalia Separator Industry $\mathrm{GmbH}$ and is shown on Figure 2 [130]. However, the recovered proteins possess a low solubility which is disadvantageous for food application [122,131-133]. This is due to their denaturation at high temperatures which additionally involves a decrease of functionality, e.g., loss of emulsifying capacity, foaming capacity or water binding capacity [134].

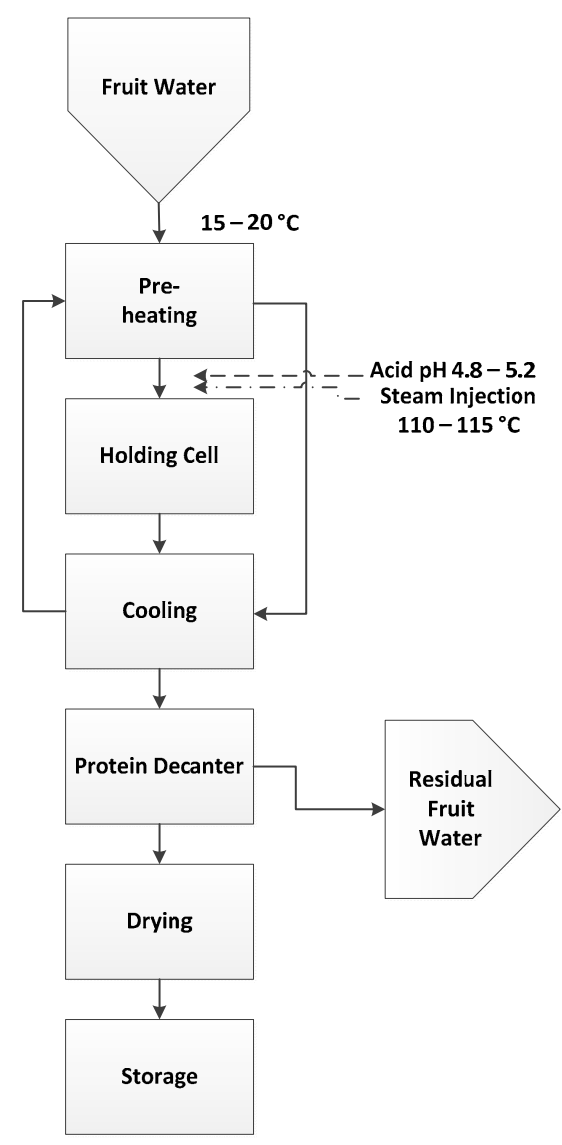

Figure 2. Protein extraction for potato fruit juice [130]. Reprinted from Starch, 51, Bergthaller, W.; Witt, W.; Goldau, H.P., Potato starch technology, 235-242, 1999, with permission from John Wiley and Sons.

Potential procedures without heat treatment are represented by membrane filtrations, e.g., reverse osmosis or ultrafiltration. During reverse osmosis an undesired salty and bitter taste of the proteins can arise and the functionality decreases. The ultrafiltration with a subsequent diafiltration is more promising because proteins with a higher quality can be manufactured and yields up to $50 \%$ arise. 
Unfortunately, these techniques are limited by the occurrence of membrane fouling at large scale processing and the presence of antinutritional factors like protease inhibitors or glycoalkaloids [119, $121,133,135]$. Additionally, protein extraction of potato fruit juice under non-denaturating conditions was described in literature: the first step is concentrating the protein by disc stack centrifugation, followed by ultrafiltration, diafiltration and optionally freeze-drying [134].

The proteins of potato fruit juice can alternatively be precipitated by ion exchange (e.g., on carboxymethylcellulose) or adsorbed by bentonite [133,136,137]. Besides proteins, amino acid fractions can be separated by utilization of ion exchange resin. Moreover, the fruit juice is desalted and protein yields of $21-32 \%$ can be achieved. Disadvantages of the adsorption procedure are high amounts of protease inhibitors which occur in the protein concentrates. Moreover, the adsorbent has to be removed prior food application [135]. An alternative to heat coagulation is the precipitation at an acidic $\mathrm{pH}$ values. Several methods were tested and citric acid as well as ferric chloride was identified as most suitable leading to soluble protein precipitates [122,138-140]. Another study examined the influence of various additives on the solubility of proteins from potato fruit juice and figured out that the addition of $\mathrm{FeCl}_{3}, \mathrm{ZnCl}_{2}$ and organic solvents (methanol, ethanol, isopropanol) increased the precipitation and resolubility [135].

Modification of extracted proteins is efficiently performed by an enzymatic hydrolysis with proteases to increase the solubility, functional properties and nutritional values [141-143]. Waglay and Karboune [120] examined the proteases Flavourzyme, Alcalase, Papain and Novo Pro-D for hydrolysis of proteins isolated from potato fruit juice and figured out that Alcalase, Flavourzyme and Papain possessed high catalytic activities whereas Novo Pro-D showed a low degree of hydrolysis. Further differences were measured with regard to the end products: Papain generated unique peptides that can be related to protease inhibitor fractions, whereas Flavourzyme mainly produced peptides which arise from protease-inhibitors.

Similar to potato fruit juice, potato processing water is a source of valuable proteins that arises throughout potato processing, e.g., during spraying on potatoes to wash the excess starch and fiber off. Protein recovery was achieved by centrifugation, membrane filtration (filter paper $2.5 \mathrm{~mm}$ and $0.22 \mathrm{~mm}$ PVDF) and ultra-filtration with a $10 \mathrm{kDa}$ PES-membrane [144].

\subsection{Purification of Potato Pulp}

After potato rasping and extraction of starch, the potato pulp accumulates in high amountsapproximately 0.75 tons of pulp arises per ton of purified starch, varying with the used plants and processes applied. Within the European Union, about 140,000 tons of dried potato pulps are generated during starch production annually $[145,146]$. The pulp mainly consists of water which amounts up to $90 \%$. Other ingredients include cell debris, intact starch cells and cell aggregates of the potato skin. Chemical analyses showed the presence of starch ( $37 \%$ of dry matter, dm), cellulose $(17 \% \mathrm{of} d \mathrm{~d})$, pectin $(17 \%$ of $\mathrm{dm})$, hemicellulose $(14 \%$ of $\mathrm{dm})$, fibers $(7 \%$ of $\mathrm{dm})$ protein/amino acids and ash $(4 \%$ of $\mathrm{dm}$ respectively) $[147,148]$. Untreated pulp can be applied as growth substrate for yeasts in vitamin B12 production or as component for other growth substrates in biogas production. The wet or partially dried potato pulp is mainly used as low value cattle feed to avoid decomposition [149,150]. De-watering is achieved by decanters and results in an increase of the dry matter from $5 \%$ to $17-18 \%$ [151]. Distinctly higher amounts of dry matter (85-86\%) can be obtained by using centrifugal sieves. An alternative is the application of pressure cloth filters, although this process is restricted by film formation and the limited processing due to batch-wise application [130]. The completely dehydrated pulp can be used in the paper industry to substitute wood fibers [152].

After extraction of nitrogen-containing components, potato pulp can be utilized as fertilizer. By hydrolysis the pulp is converted into suitable substrates for fermentations, e.g., alcohol production. Moreover, enzymatically hydrolyses are applied to modify and utilize potato pulp proteins. Kamnerdpetch, Weiss, Kasper and Scheper [141] showed that the endoprotease Alcalase and the exopeptidase Flavourzyme were most suitable while the hydrolysis can be further improved by the 
combination of both enzymes. Similarly, Waglay and Karboune [153] figured out that commercial available multi-enzymatic systems (e.g., Depol $670 \mathrm{~L}$ and Ceremix $2 \mathrm{XL}$ ) were most efficient.

Nutritional applications include the preparation of pectin or pectin-starch mixtures for the food industry as described by Abousteit and Kempf [154]. The researchers obtained pectin fractions without starch contamination by hydrolysis at $\mathrm{pH} 3.0$, atmospheric pressure and a temperature below $60{ }^{\circ} \mathrm{C}$ for 10 hours. Other studies focused on the processing of pectin fractions with high gelling abilities [155]. Separation of potato pulp into pectins and starch on the one hand, and cellulose and hemicellulose on the other was achieved by diluted sulphuric acid. Further fractionating can be performed by precipitation pectins with methanol or acetone [156]. The extraction of galactan-rich rhamnogalacturonan I of potato pectic polysaccharides is gaining attention, due to its beneficial health effects. The microwave-assisted alkaline extraction was evaluated as most promising. Therefore, potato cell walls were treated at a solid/liquid ratio of $2.9 \%(w / v)$ with $1.5 \mathrm{M} \mathrm{KOH}$ at $36.0 \mathrm{~W}$ for $2.0 \mathrm{~min}$ in the micro wave, yielding $21.6 \%$ galactan-rich rhamnogalacturonan I [157].

Recently, potato pulp was evaluated for incorporation into gluten-free biscuits, manufactured with rice flour and potato pulp. The physical and sensory acceptability was very promising [158]. Besides, the pulp was examined on its usability as solid fuel. The analyses of its energetic value, densification for pelletisation and its elemental composition led to a promising evaluation as boiler fuel in comparison to other biomass types [159]. However, as the different treatments require a lot of energy only small amounts of potato pulp are processed for technical purposes and high amounts accumulate as agricultural waste. Therefore, further investigations for an increased used are needed to improve the economically value [147].

\section{Valorization of Tomato Residues}

\subsection{Fertilizer Production from Cull Tomato and Tomato Processing Residues}

After harvesting tomato fruits huge amounts of biomass residues are left on the field (about $24,000 \mathrm{~kg} / \mathrm{ha}$, depending on cultivation conditions), namely tomato harvest stalks which include plant residues, plant wastes or residual biomass. These wastes are mainly composed of lignin (19\%), hemicellulose $(14 \%)$, cellulose $(50 \%)$ and pectin $(5 \%)$ and are therefore valuable resources for further applications [160]. In addition, industrial tomato processing generates residues (cull tomato) composed of the discards of production such as defective, damaged or immature tomatoes. These are normally discarded in the packaging houses and also in processing plants. Processing also generates discards following washing and inspection. One kilogram of processed tomatoes results in $20 \mathrm{~g}$ of discards and $20 \mathrm{~g}$ of peel and skin residues [161]. Fresh culled tomatoes comprise $14-20 \%$ crude protein, $4-5 \%$ ether extract, $22 \%$ cellulose and lignin (acid detergent fiber), 40-60\% non-structural carbohydrates (of which $90-95 \%$ are soluble sugars) and $5-10 \%$ pectins $[162,163]$. These residues often represent an added cost for the manufacturer due to the disposal procedures. Due to the putrescible nature of cull tomato wastes, a duration of storage longer than 6-7 days should be avoided [164]. During storage, uncontrolled anaerobic fermentation releases methane that has a significant greenhouse effect and influences the formation of tropospheric ozone [165].

These residues, especially tomatoes that do not meet quality standards, are usually sold at low price for animal feeding. This is partly due to the small sizes of the companies and their broad geographic dispersion. Alternatively they are used as organic fertilizers or given for free to other enterprises [166]. However, this land application is not a favored option due to increasing stringent regulations [167]. Riggi and Avola [164] suggested that an environmentally friendly waste management system should be applied which is capable of recovering valuable compounds from the wastes (e.g., lycopene). This system should be combined with a subsequent conversion of the remaining wastes by anaerobic processes (methane production) or aerobic procedures (composting). These might have positive effects like nutrient and energy retrieval and mitigation of greenhouse gas release [168]. 
Although composting is a simple and well established technology, it is regarded as a leading processing technique for several bio-wastes, including tomato plant, cull tomato or even the solid fraction obtained after their anaerobic digestion [169]. It consists of user-friendly small composting plants which are commonly available on a farm. Thereby, undegraded organic biomasses are converted and stabilized through an aerobic thermophilic bio-oxidation. Due to higher temperatures and the growth of aerobic microorganisms, composting can suppress pathogens and stabilize organic matter [170]. Thereby the soil adjustment properties can be improved. The composting process is determined by several factors, such as raw material composition, temperature, humidity, ventilation, $\mathrm{pH}$ value, and turning. To achieve a $\mathrm{C} / \mathrm{N}$ ratio of $20-30$ is recommended for digested materials [171-173]. Tomato plant stalks and especially culled tomatoes usually contain a high nitrogen concentration. Therefore, they should be co-composted with dry and carbon rich bulking agents to adjust the $\mathrm{C} / \mathrm{N}$ ratio and humidity up to $40-60 \%$. Several additions have been successfully applied to balance the initial C/N ratio of chopped tomato plants or culls such as cattle manure and sawdust [174], two-phase olive-mill pomace plus poultry manure [175,176], almond shells and sewage sludge [177], pine bark [170,178], biochar and chicken manure [179], wheat straw and separated dairy manures [180], hen manure and sawdust [181]. Composting of tomato wastes usually takes 2-4 months but advancements in composting technology have reduced its duration and improved the quality of compost by means of added specific compounds or microbial inoculums [170]. The end product (compost) can be utilized as fertilize. The compost quality produced from tomato wastes is a function of the concentration of nitrogen, phosphorous, potassium, heavy metals, pathogens or organic matter. Moreover, stability and maturity parameters as well as the absence of phytotoxins determine the quality of the compost. Previous studies have frequently demonstrated that compost from tomato wastes has adequate organic matter, nitrogen, phosphorous and potassium contents for plant growth. Mendoza-Hernandez, et al. [182] mixed composts prepared from tomato crop waste with peat in different proportions and used it as substrates for cutting rooting. Thereby, rooting, root length and root weight of cuttings was improved. Pane, et al. [183] evaluated the utilization of tomato-based composts within a tomato cropping system and obtained nutrition and bio-stimulation effects responsible for the increased productive response. It has been also reported that long-term applications of these composts improves the nitrogen status of the soil over years [184].

A similar approach for treatment of these wastes is vermicomposting, which is a result of organic matter stabilization by bacteria and worms. In greenhouse tomato production it has been successfully utilized as a substitute for peat [185]. Several studies have reported an increased tomato yield by using this product $[186,187]$. Fernandez-Gomez, et al. [188] demonstrated that by vermicomposting of tomato-plant waste together with paper-mill sludge at a ratio of 2:1 or 1:1 the recycling of both wastes is possible. The environmental sustainability of tomato crops from greenhouse production is thereby improved.

Fertilizer quality and profits of compost and vermicompost obtained from tomato plant residues can be further improved by means of extracting its components or supplementing them with microorganisms that are beneficial to plants. In agriculture processes, the use of soluble bio-waste derived substances in low concentrations, instead of conventional mineral and organic nitrogen fertilizers, could help improving plant growth and crop production in an inexpensive way. Simultaneously, the environmental impact is minimized [189]. These compounds are defined as bio-stimulants and include humic substances (HS) among others. HS can increase plant growth or even make a crop less susceptible to stressful conditions by several modes of action: activation of numerous plant metabolism pathways, increased activity of several soil enzymes, stimulation of microbial activity and an enhanced production of hormones in the soil or growth regulators in plants [189,190]. Using similar processes to those for extracting HS from the soil, peat, leonardite or lignite, organic fractions which are defined as humic-like substances (HLS) can be extracted from composted organic wastes. The basic HLS extraction process usually involves an alkaline hydrolysis $(\mathrm{pH}>10)$ of compost at high temperature and a further concentration step to reach the required HLS concentration, ranging 
from 15 to $85 \%$ [191]. Numerous composted wastes has been used for HLS extraction, namely, sewage sludge, household wastes and several animal, agrifood and agricultural residues, with tomato residues among them [192-194]. Various liquid fertilizers containing humic acids derived from organic wastes have been commercialized for application on grass, horticultural plants or crop production [195]. In spite of their positive effect on plant growth, their use is still controversial because of heterogenic nature [196]. Therefore, a process has been developed to produce homogeneous and high-value liquid organic fertilizer termed Hidrocompost ${ }^{\mathrm{TM}}$ from composted tomato plants [197]. The amount of humic substances in Hidrocompost depends on humic content in the compost that is subjected to hydrolysis [198]. Thus, analysis of the material during composting is usually required to establish the optimum composting time for humic substances extraction [199].

A step forward in formulation of fertilizers is the addition of plant-growth promoting bacteria which function as bio-inoculants in tomato residues based compost and are efficient as well as environmental-friendly alternatives to chemical compounds [200]. These have been applied to promote crop production by different bio-fertilization mechanisms, such as biological nitrogen fixation, production of phytohormones, solubilization of insoluble minerals and biocontrol processes that include phytopathogen antagonism and plant-induced resistance [201-204]. The presence of bio-protective microorganisms against plant pathogens and plant growth promoting microorganisms confers added value on tomato wasted based compost [205]. Another advantage of the interaction between microorganisms and stable organic matter is the biological substrate enrichment. The basic mechanism and benefits of the combined utilization of HS and plant growth-promoting bacteria were summarized by Canellas and Olivares [206]. Martinez-Balmori, et al. [207] described the utilization of vermicompost as a microbial carrier and reported about the ability to preserve inoculated nitrogen-fixing microorganisms [203].

\subsection{Lycopene Extraction from Tomato Skins}

Lycopene is the major carotenoid in tomatoes and is responsible for the characteristic red hue [208]. From a chemical point of view lycopene $\left(\mathrm{C}_{40} \mathrm{H}_{56}\right)$ is a tetraterpenic hydrocarbon with 13 carbon-carbon double bonds, of which 11 are conjugated occurring in various geometrical isomers. The tomato by-products mainly constituted by tomato skins and seeds represent one of the richest sources of lycopene. In fact, at the end of ripening stage, tomato skins can contain up to five times more lycopene than tomato pulp [209]. Due to its high degree of conjugation, lycopene is the most potent natural antioxidant among pigments [210]. As a natural antioxidant it may protect against chronic diseases and a broad range of epithelial cancers. According to studies in literature, lycopene may also play a role in reducing the risk of cardiovascular disease [211], osteoporosis, hypertension, male infertility and neurodegenerative diseases [212].

The main commercial use of lycopene is as a coloring agent in the food, nutraceuticals and pharmaceutical industries. Due to its deep red color, lycopene is one of the most popular natural pigments and it has been used for coloring of different food products for many years [213-216]. Compared to standard colors, it shows a good color efficiency [217]. In addition, carotenoids are used as natural antioxidants for the preparation of functional food products or as additives in order to elongate the product's shelf life $[19,218]$. In fact, processed foods are often enriched with carotenoids to improve their nutritive value. Furthermore, lycopene is widely applied in the cosmetics formulations [219-221].

Many studies in literature have reported on lycopene extraction from tomato and tomato waste, presenting a wide variety of different methods of extraction, from the conventional organic solvent extraction to the supercritical fluid extraction. Solvent extraction is the most commonly used method for the recovery of carotenoids from plant materials, due to their hydrophobicity and limited solubility in water. Regarding the extraction of carotenoids from tomato by-products, the major techniques are soxhlet extraction and agitation [218]. Several parameters can influence the yield of extraction and many studies have highlighted the optimization of these parameters. The solvent type, solvent to solid ratio, temperature, extraction time, extraction steps, particle size and moisture content can 
enhance the recovery [222]. Among these, solvent type is considered as the most important parameter. Due to its hydrophobic nature, several organic solvents have been tested for the extraction of lycopene, including ethanol, acetone, hexane, dichloromethane, ethylene acetate, benzene ethyl ether, petroleum ether and mixtures of polar and non-polar solvents $[223,224]$. However, in order to apply the lycopene extract in food products the solvents used for the extraction have to be non-toxic for human health. However, the organic solvents used in most extraction processes have adverse health effects (most non-polar solvent are considered toxic) and cannot be removed entirely. Therefore, research for alternative environmentally friendly solvents has been conducted. Among the published literature, two interesting solvents are proposed: ethyl lactate and d-limonene. Ethyl lactate is an environmentally friendly solvent which is produced by fermentation of carbohydrate fractions from soybean and corn processing. Its application in food was authorized by the U.S. Food and Drug Administration. Furthermore, ethyl lactate is colorless, has a high flashpoint and is completely biodegradable into $\mathrm{CO}_{2}$ and water $[221,225,226]$. Some extraction procedures from tomato processing by-products using this solvent resulted in the highest yield of carotenoids compared to acetone and ethyl acetate [221,227]. Limonene is the main component of essential oil resulting from fruit skins of citrus. D-limonene is extracted from orange peel through steam distillation and is mainly used as a solvent for extracting lycopene from tomato, instead of dichloromethane [228]. Even though the final yield of lycopene extraction with d-limonene is lower than with dichloromethane, the procedure can be considered as an interesting alternative to conventional organic solvents.

As reported in literature [229], sonication enhanced the extraction yield of lycopene from tomato with minor degradation and isomerization. Furthermore it allowed the application of lower extraction temperatures and a shorter extraction time. However, the technique still requires organic solvent to perform the extraction.

Solvent extraction of lycopene is often performed at temperatures higher than room temperature and long heat treatments can cause a degradation of lycopene. Therefore, microwave-assisted extraction may provide a solution to this problem. In fact, microwave quickly heats extracts, accelerating the adsorption and desorption of the targeted compounds from matrix. In particular, the migration of lycopene into the extraction solvent is enhanced by superheating of the polar cellular components. Whereas the heat impact on non-polar components is limited by short treatment periods $[230,231]$. The extraction arises due to modifications in the cell structure, caused by electromagnetic waves [232]. The use of microwave assisted extraction on levels of lycopene isomers has been investigated. In fact microwave and ultrasound can be combined together, as reported in Lianfu and Zelong [233]. These authors combined ultrasonic and microwave assisted extraction in one instrument to extract lycopene from tomato by-products. By this, the extraction yield of lycopene was significantly improved. Microwave assisted extraction has some advantages compared to the conventional extraction techniques, including lower environmental pollution due to reduced consumption of solvent, higher extraction efficiency and a shorter extraction time. On the other hand, some disadvantages have been reported e.g., additional filtration or centrifugation is required to remove solid residues. Moreover, the efficiency of microwaves might be influenced by applying non-polar or volatile target compounds [214,231,234].

Enzyme-assisted extraction could also improve conventional extraction of lycopene from tomato residues. In fact, enzymatic treatment may be used before conventional solvent extraction process, as a pretreatment. Enzyme-assisted extraction utilizes the cell wall degrading ability of enzymes, allowing the extraction of bioactive compounds. This process offers a more environmental friendly approach. Several studies have investigated the application of enzymes to increase the extraction yield of lycopene from tomato by-products. The most used enzymes were cellulases and pectinases, followed by solvent extraction with acetone, hexane, petroleum ether, ethyl acetate or mixtures of solvents [214,235-238]. In all cases, a significant increase of the extraction yield was observed, compared to the untreated samples. Besides, in all these studies pectinase was more effective than cellulase in extracting lycopene, especially from tomato peels. This can be probably explaine its' pectinolytic activity, since the pectin 
network within the tomato peel tissue is the main reason for the unavailability of lycopene. When pectic substances are enzymatically degraded, disintegration of the plant tissue occurs, with lycopene becoming easily accessible, as explained by Lavecchia and Zuorro [236]. Finally, an interesting possibility is presented in a recent paper, where unlike currently proposed enzymatic assisted lycopene extraction techniques lycopene is extracted by tomato waste skins using a green chemistry protocol without organic solvent [239]. In fact, it still includes the utilization of organic solvent after the enzymatic pre-treatment. The method proposed by Cuccolini et al. [239] does not use organic solvents, since the aim of the method is to isolate the chromoplasts from tomato peels, where lycopene is stable because it is still incorporated in its natural medium. The present method, exploiting hydrolytic enzymes in combination with aqueous solutions at different $\mathrm{pH}$ values, leads to an increase in the chromoplast yield by separating other cell components. The lycopene in the final product is protected against oxidation as it is still incorporated in the chromoplast [239].

Enzymatic pretreatments exhibit some advantages including reduction in extraction time and solvent consumption, increased yield and quality of product. However, some limitations still exist such as the high costs of enzymes, the inability of enzyme preparations to completely hydrolyze plant cell walls and the difficult industrial feasibility of the conditions required for the treatment [240].

Lycopene extraction can also be performed by means of organic solvent, but with the aid of high pressure. Extraction with high pressure is applied by employing temperatures from 50 to $200{ }^{\circ} \mathrm{C}$ and pressures from 9 to $15 \mathrm{MPa}$, which is known as pressurized liquid extraction or accelerated solvent extraction. The high temperatures positively affect the extraction and due to the high pressure applied, the solvent is maintained in the liquid state. Under these conditions the liquid solvent is forced into the matrix and the biocompound solubility is increased. An interesting application is reported by Naviglio, Caruso, Iannece, Aragòn and Santini [213], where a pressurized extraction method by use of the Extractor Naviglio is employed. Through this device lycopene is extracted from industrial tomato by-products at a pressure of 0.7-0.9 MPa using tap water as extracting liquid. Although lycopene is not soluble in water it forms molecular aggregates, which can be extracted by pressure/depressure cycles. Another possibility is to use higher pressure (100 to $800 \mathrm{MPa}$ ) and low temperatures (usually room temperature), which is known as high hydrostatic pressure extraction. This technology has been successfully applied for the extraction of several bioactive, plant-based compounds, such as carotenoids from tomato processing products. Recently, Strati and Oreopoulou [214] examined the use of several organic solvents for the extraction of carotenoids, and especially lycopene, from tomato processing waste. The authors found that high hydrostatic pressure extraction resulted in higher extraction yields compared to conventional solvent extraction process performed at room temperature for $30 \mathrm{~min}$. The advantages of using high pressure for extraction processes are shorter processing times, reduced solvent consumption and higher extraction yields. In addition the high hydrostatic pressure extraction has the advantage of being to operate at room temperature. While using lower pressure (pressurized liquid extraction), the temperature has to be increased which could affect the functional activity and structure of the bioactive compound.

Finally, supercritical fluid can be employed to perform lycopene extraction. Supercritical fluid extraction (SFE) is an environmentally friendly technology and based on the fluids properties. By raising pressure and temperature over the critical point, the solvating power of the gas is increased [215]. The most widely used compound is $\mathrm{CO}_{2}$, due to its low critical temperature and pressure. $\mathrm{CO}_{2}$ represents a favored alternative to organic solvents because it is inexpensive, non-explosive, non-toxic and can be easily removed from the final products. Furthermore, lipophilic substances can be solubilized by the use of $\mathrm{CO}_{2}$. Most of the research studies on SFE for the carotenoid recovery have focused on tomato products and tomato wastes $[215,241]$. All these studies demonstrated that by increasing the pressure and/or temperature of $\mathrm{CO}_{2}$, the extracted amount of lycopene rose. This is due to the increased density of the supercritical $\mathrm{CO}_{2}$, which leads to an improved ability to solubilize carotenoids. However, in the first two studies mentioned the extraction of lycopene is improved by using also a co-solvent like ethanol or hexane. Instead, Rozzi, et al. [242] demonstrated 
that lycopene can be extracted with significant success from industrial tomato by-products with SFE using $\mathrm{CO}_{2}$ without any other co-solvents. The results of this study indicated that the concentration of lycopene increased with higher temperature and pressure. The main advantages of SFE are the high target specificity, short extraction times, the use of non-toxic organic solvents and that pollution is reduced [243]. Disadvantages could be represented by its high operating costs, since high pressures have to be applied to maintain the fluid in supercritical state.

\subsection{Cutin Extraction from Tomato Skins}

With 40 to $85 \%(w / w)$, cutin is the main component of the tomato plant cuticle. A tomato cuticle forms a protecting film covering the epidermis of tomato fruits. It consists of lipids, polysaccharides (mainly cellulose and pectin), polypeptides, phenolic compounds and hydrocarbon polymers impregnated with wax. It is synthesized exclusively by the epidermal cells [244]. Thus, the plant cuticle can be considered as polyester waxes complex associates, with a very small hydrophobic nature reactivity, since most of the carboxylic groups present in the membrane are esterified with aliphatic hydroxyl groups of other fatty acids.

Due to the cuticle weight (around $600 \mu \mathrm{g} / \mathrm{cm}^{2}$ ), it can be termed as the major lipid plant polymer. Chemically, cutin consists of a polymeric network of polyhydroxylated C16 and C18 fatty acids which are linked by ester bonds [245-247]. Cutin plays an important role as a structural component in the cuticle, as a defense barrier against pathogens [248], as protection against the loss of water and waxes [249], as well as in carrying substances through plant tissues [249]. Commonly, cutin is extracted from plant material using enzymatic treatments, organic solvents or acid hydrolysis. Enzymatic treatments degrade cell walls and membranes of cuticle as they destroy polysaccharides. In most of the studies reported in literature enzymatic treatments act as a pretreatment to degrade the cuticle, prior an extraction with organic solvents. The most used enzymes are cellulase and pectinase, generally employed in acetate or phosphate buffer $[250,251]$. These enzymes degrade plant cell wall components and disrupt the structural integrity, thus increasing the cell wall permeability [240].

By extraction with organic solvents lipid components of the cuticle are isolated, obtaining a dewaxed cuticle. Generally, the solvents used are chloroform and methanol in the Soxhlet apparatus. The extraction of cutin using acetone in a Soxhlet apparatus for 24 hours followed by a reflux of the obtained solid material in a solution of propanol has been reported and patented [252]. Another organic solvent used to extract cutin from tomato skins is prepared by dissolving potassium hydroxide in methanol. With this method the solid cutin is isolated and then precipitated by acidification [253]. In addition, Luque, et al. [254] proposed the extraction with diethyl ether of the de-waxed product derived from saponification to isolate cutin from mature tomato green cuticles.

Finally, another possibility to obtain cutin is by acid hydrolysis. By this means cutin samples are obtained after hydrolysis of dewaxed cuticles in an acid solution $(6 \mathrm{M} \mathrm{HCl})$ for $12 \mathrm{~h}$ at $105{ }^{\circ} \mathrm{C}$ to remove polar hydrolysable components. Afterwards, samples are depolymerized in a $3 \%(w / v)$ sodium methoxide solution for $18 \mathrm{~h}$ at $100{ }^{\circ} \mathrm{C}$ [246]. However, a first initial treatment with organic solvent to dewax the cuticle is necessary.

In the literature there are some examples of cutin extraction methods combining organic solvent extraction and acid hydrolysis $[255,256]$. In some cases, an additional pretreatment of tomato skins is performed, which consists of a heat treatment with oxalic acid and ammonium oxalate to remove the residual pulp, that can remain attached to the skins [257]. Previous methods which successfully conducted organic solvent-free cutin extractions are very scarcely, in particular using tomato by-products as raw material. In fact, all methods reported aimed at analyzing the composition of cutin. However, no information is available regarding the use of cutin as raw material for other preparations. Instead, the method patented by SSICA and CTAEX in the previous European FP7 project BIOCOPAC (GA 286446, WO2015/028299 A1), is solvent-free and feasible to industrialization or scale up [258]. This extraction process consists of a solubilization of tomato skin in alkaline solution. The skins are mostly soluble in alkaline solution and this method exploits this property. Afterwards, 
the tomato skins are subjected to thermal treatment with an alkaline solution (saponification). Subsequently, the raw cutin in solution as sodic resinates, was separated and cleaned of impurities, essentially by filtration and centrifugation. Finally, the solid extract is precipitated by acidification, separated and purified by centrifugation. The extracted cutin can be used as a protective coating for metal food containers to develop completely recyclable packaging [259]. The study showed that the bio-lacquer can be applied on different metal substrates (e.g., aluminum, tinplate and tin free steel) with good chemical and mechanical properties.

\subsection{Further Utilization of Tomato Plant and Tomato Processing Residues}

Energetic use of tomato plant waste was proposed by Encinar, et al. [260]. The gas phase produced by pyrolysis process of the tomato plant waste mainly composed of $\mathrm{H}_{2}, \mathrm{CO}, \mathrm{CH}_{4}, \mathrm{CO}_{2}$ and small amounts of ethane and ethylene. The solid phase consists of charcoal with an average higher heating value (HHV) of $26 \mathrm{MJ} / \mathrm{kg}$, the liquid phase presents a $\mathrm{HHV}$ of $7.8 \mathrm{MJ} / \mathrm{kg}$ at $400{ }^{\circ} \mathrm{C}$. The key operation variables of the process are the temperature $\left(400-800{ }^{\circ} \mathrm{C}\right)$, the sample mass and the particle size.

Among all different biomass conversion technologies of tomato plant wastes (TPW) the hydrothermal liquefaction is of great interest. This presumably derives from the fact that this process can efficiently be used to transform inedible biomass into bio-oils (or bio-crude oils) which can be applied as a source for chemicals (e.g., bio-phenols or bio-polyols) or can be valorized by converting into drop-in bio-fuels, like biodiesel [261].

Other uses of TPW were proposed in literature. For example, the conversion of non-edible polysaccharides and tomato plant waste to levulinic acid has been developed by a microwave-assisted method. A total conversion has been achieved and clean levulinic acid was obtained without any purification in high yields (63-95\%) by 2 min irradiation [262].

Tomato leaves were used to extract volatile aroma components. The volatiles of tomato leaves were isolated by adsorbent trapping and by direct solvent extraction [263]. The application of volatiles from tomato leafs as antifungal compounds against plant pathogenic fungi was proposed by Baldwin, et al. [264].

Polyphenolic antioxidants can be extracted from tomato skins by liberating these compounds from the vacuolar structures where they are found, either through rupturing plant tissue or through a process of diffusion [265]. Water, aqueous mixtures of methanol, ethanol and acetone are commonly used as solvents [266]. The selected extraction method should result in a complete extraction of the compounds of interest and avoid their chemical conversion [267].

A further possible application is the production of food microorganisms using tomato wastes. Supplemented tomato wastes have been tested as alternative culture medium for the production of carotenoids by Rhodotorula glutinis [268]. The authors found that higher concentrations of yeast extracts negatively affected the formation of biomass but favored carotenogenesis while higher amounts of glucose in the medium increased biomass formation. In another study, valorization of tomato waste proteins was investigated by Moayedi, et al. [269]. They revealed that the proteolytic bacterium Bacillus subtilis produced antioxidant and antibacterial hydrolysates during fermentation of the protein fraction of tomato seeds.

\section{Valorization of Cereal Processing Residues}

\subsection{Cellulose Extraction from Wheat Bran and Oat Husk}

Cereals are the most commonly cultivated crops worldwide. Cereal grains are regarded as one of the most important sources of carbohydrates, dietary proteins, vitamins, minerals and fibers [270]. Wheat, together with maize and rice, accounts for about $90 \%$ of the world's cereal production, and for about half of the total cereal production within the EU [271,272]. Based on previous data wheat is of great importance to the EU economy and wheat-derived by-products can be considered as a feedstock for biorefinery development. Current worldwide wheat global production is more than 700 
million tons per year $[271,273]$ and about one-fifth of the cultivated wheat is converted into bran (90 to 150 million tons/year) [273,274]. Currently, the bran is mainly used as a feed supplement, while minor amounts are applied in food [275]. However, there is great interest in innovative technologies for valorizing wheat bran through its conversion into value-added biomolecules [270].

Cellulose, the most abundant polysaccharide in nature, has been purified from natural resources and utilized in a myriad of applications for thousands of years. Natural cellulose fibers from cotton, flax, hemp, and sisal, have been utilized for millennia due to their outstanding properties in textile applications $[276,277]$. Furthermore, wood and non-woody plants such as bamboo have been applied extensively for the production of paper and cardboard both for printing and packaging applications [278-280]. Figure 3 summarizes the most widely used resources for the production of cellulosic fibers.

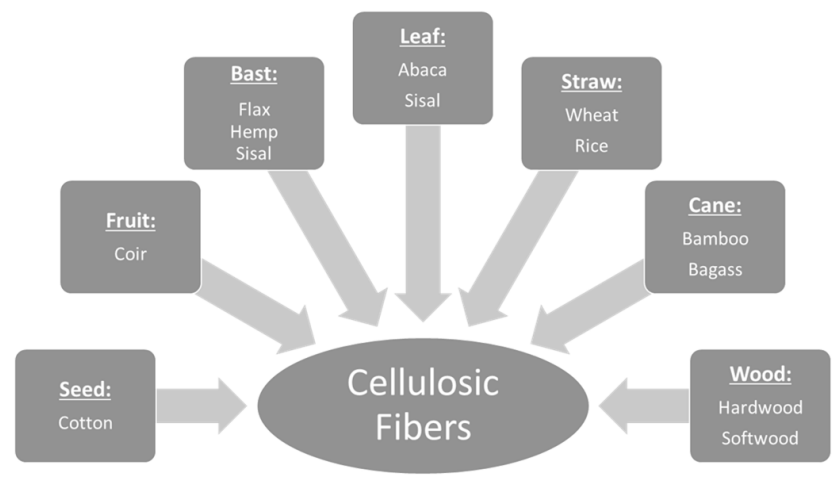

Figure 3. Common natural resources used for the production of cellulosic fibers. Adapted from Akil, et al. [276]. Reprinted from Materials \& Design, 32, Akil et al., Kenaf fiber reinforced composites: A review, 4107-4121, 2011, with permission from Elsevier.

Advantageous features, such as biodegradability, low costs, high specific strength and light weight, resulted in the comprehensive development of this environmentally friendly bio-based material [281]. In the last two decades, a new family of cellulose-based nanoscale building-blocks has appeared. New technologies have allowed disintegrating cellulose fibers into nanofibers at a reasonable cost [282-284]. These new nanofibers have diameters from 2 to $20 \mathrm{~nm}$ and lengths in the range of several $\mu \mathrm{m}$. Due to their immense available surface, compared with micrometric fibers, cellulose nanofibers (CNFs) offer an enormous potential for a wide range of applications, from reinforcement in composite materials to viscosity modifier in suspensions [285]. However, CNFs have been mostly produced from bleached wood pulp, which is used to produce fine paper, and thus has a considerably high price compared to non-renewable materials such as commodity polymers, e.g., PP and PE. Therefore, some researchers have focused on the production of CNFs from agricultural residues, not only to decrease their cost, but also to mitigate the environmental impact of agricultural waste, moving towards a biorefinery concept. Recently, an extensive review from Jonoobi, et al. [286] detailed the different preparation methods for CNFs from various natural resources and residues. Agricultural resources and residues such as wheat straw and soy hulls [287,288], empty fruit bunches [289], sugar beet pulp [290], potato pulp [291], swede root [292], bagasse [293,294], rice straw [293], banana rachis [295] and banana peels [296], have been used as a raw material for the production of CNFs. The extraction is conducted by mechanical processes, e.g., high-pressure homogenization, grinding, refining treatments or by acid hydrolysis. By mechanical treatments it is possible to isolate CNFs from cell walls without distinct cellulose degradation [286]. A comparison of three different mechanical processes showed that microfluidization and grinding needed less energy than homogenization. Moreover, the first-mentioned techniques provided higher film toughness [297].

Several studies were conducted to find new alternative sources for obtaining nanocellulose by valorizing all non-valuable raw materials existing in the nature. For example, oat husk residues from 
cereal processing were converted into $\mathrm{CNFs}$ which were used as a reinforcing agent in the production of bio-composites for packaging applications [26]. Furthermore, some publications have reported the production of CNFs from sesame and rice husks [298]. However, to the best of our knowledge, even though there are large numbers of papers in the production of CNFs using agricultural residues, there are no reports of CNFs from wheat bran. Therefore, this could be a further opportunity to enhance the sustainability of wheat cultivation and processing.

\subsection{Production and Extraction of Oligosaccharides and Phenolic Acids from Wheat Bran}

\subsubsection{Extraction of Biomolecules from Bran}

Wheat bran is multi-layered (pericarp, testa, hyaline, aleurone layers and residual starchy endosperm) and consists of different cell types with various chemical compositions. Generally, it consists of approximately $12 \%$ water, $13-18 \%$ proteins, $57 \%$ carbohydrates, $4 \%$ fats and $1 \%$ phenolic acids. Wheat cell wall contains high amounts of oligosaccharides (such as arabinoxylan dietary fibres) and phenolic acids, mainly ferulic acid (FA) that acts as a cross-linker binding to sugar residues $[299,300]$.

The chemically heterogeneous composition of wheat bran makes it a potential feedstock for biorefinery processes aiming to obtain a wide variety of compounds, which may be either valuable per se, or as precursors of commodity and building block chemicals [299]. Two different routes of wheat bran valorization have been recently carried out aiming at the extraction of carbohydrate and/or non-carbohydrate-based products. Concerning the carbohydrate fraction, the most interesting proposed valorization routes include the extraction and conversion to bio-based chemicals, e.g., lactic acid, poly lactic acid, succinic acid. Likewise, the recovery of arabinoxylans and their conversion to xylose and xylitol and, to a lesser extent, the extraction of $\beta$-D-glucans are promising [299]. Valuable components in the non-carbohydrate fraction are FA and other phenolic acids, followed by proteins, amino acids and wheat bran oil. More than $90 \%$ of the phenolic acids are present in a bound form [299,301,302]. FA is the most abundant phenolic acid $(0.2-15 \mathrm{~g} / \mathrm{kg})$ and is mostly linked to cell wall polysaccharides or lignin by ester and ether bonds. This compound has demonstrated beneficial activities for human health (such as antioxidant, anti-cancer, improving vascular function), and thus has a high potential of application in the food, health and cosmetic industry $[275,299,300,303]$. Moreover, FA isolated from crop by-products can be bio-converted into natural vanillin [304].

The extraction of wheat bran components includes a range of different steps. Pretreatments may be necessary to increase the extraction efficiency, e.g., by selecting the bran fraction richer in the target product, increasing the matrix surface/volume ratio and/or the matrix de-structuration, or by removing unwanted components before the extraction of the target compound. On the other hand, pretreatment represents one of the most expensive processing steps in wheat bran biorefinery [305] and can affect further exploitation of the recovered compounds (e.g., solvent extractions may limit food application). Fractionation of the raw material allows simplification of its composition, to easily isolate specific high-value components and to obtain a more efficient hydrolysis of fermentable sugars (e.g., for ethanol production) $[275,305,306]$. Particle size reduction, due to milling process, was found to improve the recovery of phenolic acids, anthocyanins and carotenoids [307], whereas extensive ball-milling was found to be the most promising and specific mechanical pretreatment for the recovery of xylan-based polysaccharides and arabinoxylans [308].

Among thermal treatments, liquid hot water saccharification (especially for lab-scale optimization) and steam explosion (more applicable to industry) are the most common. Both methods apply similar mechanisms for matrix destructuring, based on hot water biomass treatment under high pressure, which is released either gradually (in liquid hot water treatment) or rapidly (steam explosion) [306]. Recently, steam explosion-assisted extraction was found to be particularly effective in phenolic acid extraction, with a recovery yield gradually increasing with residence time and temperature [309]. The increase of ferulic and diferulic acids release from destarched bran has been in particular associated 
to the degradation and depolymerisation of the hemicellulosic arabinoxylans, along with some breakdown of cellulosic glucose [310]. Thermal pretreatment is often adopted because of the simplicity of the required equipment and the absence of corrosive and hard to recycle chemicals [311]. Generally, it is performed at $180-190^{\circ} \mathrm{C}$ for $10-20 \mathrm{~min}$ to avoid the formation of toxic compounds, such as furfural and 5-hydroxymethyfurfural, generated from hexose and pentose degradation [305,306,311].

Ultrasonication is a process able to destructure plant cell walls and to release polysaccharides and other less extractable compounds in a shorter time and at lower temperatures. Short ultrasoundassisted extraction was used to isolate hemicellulose components (mainly phenolics-rich heteroxylans) of industrial wheat bran, leading to a sugar yield similar to that of the standard alkaline extraction. Besides, a shortening of the process by about $60 \%$ with a lower sodium hydroxide consumption can be achieved [312]. When aiming at phenolic acid recovery an ultrasonic procedure was found to be more effective than microwave extraction, due to the gelatinization of starch induced by microwave treatment [313].

Classical chemical extractions of oligosaccharides and phenolic acids from wheat bran involve acid (such as sulfuric acid), alkaline (sodium hydroxide) and hydrogen peroxide treatments [308]. Solvent extraction offers the opportunity to partially disintegrate and fractionate biomass, but is less used in wheat bran exploitation. It was demonstrated that different ethanol/water ratios were more effective in combination with enzymatic treatment [311]. The performance of the ethanol/water-enzyme process was similar to the hydrothermal-enzyme one, with about $85 \%$ of the feedstock dissolved into the liquid phase [273,311].

Enzymatic digestion of wheat bran can be considered either as a pretreatment, when the aim is to remove interfering molecules for further process steps (such as bioethanol production), or as an extraction technique, when the goal is the recovery of specific compounds (such as phenolic components or oligosaccharides). The use of amylase and/or xylanase, cellulase and hemicellulase for monomeric sugars or oligosaccharides isolation, and of protease for peptides and proteins, has been largely reported [273,305,306,311]. Feruloyl-esterase was tested for FA and other phenolic acids release, but due to the extremely complicated structure of the cell wall, its combination with an array of enzymes having different digestion activities (e.g., xylanase) can be more effective [304]. Sequential enzymatic digestions ( $\alpha$-amylase, glucoamylase, xylanase) have been proposed for the recovery of a mixture of xylo-oligosaccharides [314], although the recovery of specific oligosaccharides can be hampered by the co-extraction of other cell compounds [308]. Compared to chemical approaches, enzymatic treatments are more cost and energy effective, more selective, produce a greater range of fractions with different chemical, functional and technological characteristics and do not require the solvent recovery and purification [275].

Extraction processes are typically followed by one or more purification steps, usually based on adsorption and desorption with high specific resins and/or with activated charcoal, or on compounds solubility in different solvents [299].

Often a multi-step processes combining different type of treatments has been proposed for wheat bran valorization. For example, Hromadkova, et al. [315] sequentially extracted two different water-soluble arabinoxylan fractions: the first obtained during enzymatic digestion of protein and starch, the second recovered via sodium hydroxide hydrolysis. Wood, Cook, Wilson, Ryden, Robertson and Waldron [306] recently suggested a multi-step wheat bran biorefinery consisting of sequential amylase, protease and xylanase digestion (leading to starch removal and to the recovery of arabinoxylans, glucose, xylan and arabinan and of proteins) followed by a thermal treatment (liquid hot water or steam explosion) and a cellulose digestion, before the final conversion of fermentable sugars to ethanol.

\subsubsection{Valorization of Ferulic Acid (FA) and Aromatic Compounds as Monomers for Polymer Synthesis}

Based on the current state of the art and inevitable future technological improvements, wheat bran can be considered as a highly versatile mass by-product suitable for biorefinery challenge and valorization. In fact, wheat bran can be used as a source of phenolic and aromatic compounds that 
can be key intermediates in the production of polymers [316]. Indeed, aromatic compounds offer rigidity, hydrophobicity, resistance against fire and the derived polymers are characterized by good thermomechanical and barrier properties. The following section will focus on the preparation of thermoplastic polymers from aromatic phenolic compounds. Among these, ferulic and vanillic acids are most available in plant-based wastes can be used for the production of polyesters. This processing represents a possible means to increase the sustainable utilization of agricultural and food resources. Therefore, the focus will be on sustainable and green processes.

The first example of the valorization of vanillic acid as monomer was reported in 1955 [317]. Vanillic acid from lignin was transformed to carboxylate by etherifying the phenolic moiety with ethylene dihalides and then the carboxylate was esterified with ethylene glycol and gave rise through condensation to a linear polyester. The resulting polymer had a glass transition temperature ( $\mathrm{Tg}$ ) of $80{ }^{\circ} \mathrm{C}$ and a melting temperature $(\mathrm{Tm})$ of $210^{\circ} \mathrm{C}$ [318,319]. Later, Lange and Kordsachia [320] in 1981, developed a new strategy to polymerize vanillic and syringic acids. In the new synthetic pathway, the phenolic functional group of vanillic acid was reacted with ethylene oxide, giving rise by condensation, to polyester with different aromatic substituents. The polymer obtained from vanillic acid demonstrated thermal performances very close to poly(ethylene terephthalate) (PET). However, the use of ethylene oxide requires an apparatus suitable for the treatment of toxic and explosive gases. Although the reaction delivers complete conversion, the desired hydroxy-acid was only obtained after precipitation with sulfur dioxide, followed by sublimation and crystallization with a mixture of methanol and ethyl acetate. Then, the use of solvents is necessary for the purification step.

In 2010, the synthesis of bio-renewable PET mimics, synthesized from lignin and acetic acid was reported [321]. In particular, vanillin and acetic anhydride were employed and through the production of acetyldihydroferulic acid a homo-polymerization was conducted. It was demonstrated that zinc acetate was the most efficient catalyst and the final material exhibited a $\mathrm{Tm}$ of $234^{\circ} \mathrm{C}$, a $\mathrm{Tg}$ of $73^{\circ} \mathrm{C}$ and $50 \%$ thermal decomposition $(\mathrm{Td})$ at $462{ }^{\circ} \mathrm{C}$. The corresponding values of PET are very similar: $\mathrm{Tm}=265^{\circ} \mathrm{C}, \mathrm{Tg}=67^{\circ} \mathrm{C}$ and $\mathrm{Td} 50 \%=470{ }^{\circ} \mathrm{C}$.

Similarly, vanillin, 4-hydroxybenzoic acid and syringic acid were employed for the synthesis of poly(alkylenehydroxybenzoate)s (PAHBs) [322]. Through a series of reaction steps hydroxyl-acid monomers were obtained and then homo-polymerized using antimony oxide as a catalyst, yielding a wide variety of thermomechanical properties as a function of the aromatic substitution. In this series of polymers, $\mathrm{Tg}$ was ranging between 50 and $70^{\circ} \mathrm{C}$ and $\mathrm{Tm}$ between 170 and $239^{\circ} \mathrm{C}$ were reported. A more sustainable chemical pathway from vanillic acid to polyethylene vanillate has been recently reported [323]. In fact, etherification reactions of phenolic compounds with a bio-based reagent, ethylene carbonate, instead of chloroethanol, represent an eco-friendly way to improve the reactivity of the phenolic functionality. Then, a final solid state reaction results in a relatively high molecular weight (about $5000 \mathrm{~g} / \mathrm{mol}$ ). No purification steps are necessary and solvents are not used. Moreover, properties can be easily tuned by copolymerization.

Recently, FA and derivatives of vegetable oil were employed to synthesize fully bio-based polyesters. In particular, a polyester from FA was produced by polycondensation [324]. First, FA was derivatized into a more reactive molecule then, methanol was used to esterify the carboxylic acid and the resulting ester was hydrogenated and further reacted with two equivalents of ethyl carbonate. The corresponding semicristalline polyester was produced by a catalytic homopolymerization, and the final polymer exhibited a low molecular weight, a $\operatorname{Tg}$ of $-27^{\circ} \mathrm{C}$ and a $\mathrm{Tm}$ of $25^{\circ} \mathrm{C}$. Amorphous polymers were also synthesized by copolymerization with methyloleate and methylerulate derivatives. The same authors also reported the polycondensation of a vanillin derivative, another phenolic compound derived from biomass. The reaction strategy employs thiol-ene addition and yields semicristalline polymers [325].

Another path for polyesters synthesis starting from derivatives of phenolic biomass is based on the coupling of phenolic substrates in order to obtain di-functional monomers [326,327]. For example, by the copolymerization of dicarbonyl functionalities with derivatives of vegetable oils, Pang, Zhang, 
Wu, Wang, Gao and Ma [326] obtained fully bio-based semi aromatic polyesters. The coupling of several phenolic compounds to produce difunctional monomers, was also investigated by employing enzymatic reactions [328].

Recently, Goto, et al. [329] developed a copolymer of FA employing glycine. They obtained an amorphous material characterized by a high thermal stability and a $\mathrm{Tg}$ at $189^{\circ} \mathrm{C}$.

\subsubsection{Valorization of Aromatic Compounds as Additives for Polymer Formulation}

FA has gained considerable attention for its use in preventing oxidation and further beneficial properties. As a photo-protective and antioxidant agent, FA also protects against dangerous radiation effects as a UV absorber and as a free radical scavenger [303,330,331].

Free FA is a good antioxidant due to its ability to produce stabilized phenoxyl radicals by donating hydrogen atoms. FA has shown high scavenging activity for hydrogen peroxide, superoxide anions, hydroxyl radicals, and nitrogen dioxide free radicals [330]. FA also possess the ability to react with polysaccharides and proteins through crosslinking reactions, indicating that it can be used in the preparation of biomedical, pharmaceutical, food and cosmetic products $[330,332]$. To control the release of FA via diffusion, it has been incorporated into a hybrid material or has been modified with polymers containing cinnamoyl moieties to improve photostability [333].

These characteristics of FA can also be exploited in polymer formulations since during the processing and service life polymers are subjected to oxidative degradation due to exposure to light and temperature. Nevertheless, although FA exhibits beneficial properties, it can undergo decomposition by temperature, air, and light, which reduces its efficacy. In general, the main drawback related to the use of extracted natural phenols is their generally limited temperature stability, which causes their degradation during the polymer melt processing. Furthermore, natural phenols have often limited solubility in polymers [334].

Derivatization is a way to adapt natural antioxidants to their use in polymers. In fact, by derivatizing hydroxycinnamic compounds, an increase in their activity and thermal stability can be obtained. Another approach is their insertion into an inorganic host filler in order to avoid diffusion as well as to limit as much as possible their thermal degradation and reactivity with polymer chain [335].

The derivatization of FA and its use as antioxidant additives were reported [336,337]. The authors enzymatically synthesized bis- and trisphenols from FA and bio-based diols (butenediols, propanediols and isosorbide) or triols (glycerol). Afterwards, their antioxidant activity at different concentrations and processing methods were investigated in polypropylene (PP) and polybutylene succinate (PBS). In case of PBS, the trisphenols antioxidant was more efficient, while in the case of PP the commercial antioxidant Irganox 1010 was better. Indeed, they reported difficulties during melt compounding of PP due to sticking in the feeder and condensation on the extruder equipment. These problems were avoided by processing PBS with solvent casting. However, solvent casting is not in line with green chemistry. Good efficiency of natural extracts was also observed under the thermal stress and processing under oxygen with PP [338].

Coelho, Hennous, Verney and Leroux [335] developed a strategy for the insertion of FA and other natural antioxidants inside layered double hydroxide. The UV shielding properties were tested when melted inside PBS. They reported that a better UV stability was not fully demonstrated but an enhancement of rheological properties was obtained and less carbon dioxide during photo-degradation was formed. On the other hand, crosslinked polymers with antioxidant properties were synthesized by inserting FA in a polymer based on methacrylic acid (MAA) and using ethylene glycole dimethacrylate as co-monomer and crosslinker [339]. Co-polymers of FA and methacrylic acid were also manufactured in the work of Iemma, et al. [340] with antioxidant and antifungal properties.

FA has also been effective for increasing the thermal and mechanical performances of PLA. In fact, by introducing biomesogenic units the thermal stability and the elastic properties improved, while the $\mathrm{Tm}$, the degree of crystallinity and the rate of enzymatic degradation reduced [341]. Cerruti, et al. [342] incorporated phenolic compounds derived from wine production residues in starch biopolymers. 
This natural additive caused a plasticization effect in the obtained extruded films and promoted an earlier disintegration.

According to Kim, et al. [343] and Rizzarelli and Carroccio [344] PBS can undergo three different degradation mechanisms depending on the storage conditions. Like all polyesters, PBS is sensible to hydrolysis by exposure with liquid water or water vapor. In the absence of water, heat, UV light or mechanical stress it can produce primary radicals on the polymer backbone leading to the formation of peroxyl radicals. In the presence of oxygen it caused the formation of peroxy radicals. This process can be interrupted by primary antioxidants. Aiming at proposing bio-based antioxidants, the use of natural hindered phenolic compounds exhibiting antioxidant activity has received increasing interest. Examples are $\alpha$ - tocopherol, lignin, carvacrol, thymol or curcumin.

Poly-anhydride-esters based on FA can enable controlled bioactive release and protect bioactive functional groups from degradation. In this study by incorporating FA into a polymer backbone FA retained its antioxidant activity when released via polymer degradation. Further, the FA-based polymer prevented discoloration, indicating a promising FA-based topical formulation [334].

\subsection{Production of Food Microorganisms Using Cereal Processing Residues}

The production of different bacterial and yeast strains using wastes from cereal processing have been reported several times and is an effective way to valorize unexploited by-products. Poopathi and Archana [345] investigated the production of Bacillus thuringiensis from powdered wheat bran, chickpea husk and corncob as well as their combinations. It was observed that corncob supplemented with $\mathrm{MnCl}_{2}$ was as effective as Luria-Bertrani medium for the production of Bacillus but 50 times less expensive. To perform liquid fermentation with these by-products they were boiled and extracted. Wheat straw, barley straw, oats hull, chili stubble and starch-glucose powder were used for solid fermentation of S. cerevisiae. Biomass and digestibility of the protein obtained were determined [346]. The production of single cell proteins from Candida utilis and Rhizopus oligosporus by microbial conversion of wheat bran has been studied. Growth parameters including inoculum size and age, temperature and incubation period were optimized for this process [347].

The performance of six microorganisms of industrial relevance (Escherichia coli, Corynebacterium glutamicum, S. cerevisiae, Pichia stipites, Aspergillus niger and Trichoderma reesei) were tested for their ability to grow on lignocellulosic biomass hydrolysates obtained from sugar cane bagasse, corn stover, wheat straw and willow wood. In addition, their resistance to growth inhibitors present in these hydrolysates was evaluated [108]. For this, raw materials were previously hydrolyzed by enzymatic or acid hydrolysis using concentrated sulfuric acid. Some growth inhibitors (e.g., furfural, acetate) were contained in acid hydrolyzed feedstocks. However, all tested microorganisms showed a good growth behavior on the pretreated materials. Pichia stipites and Aspergillus niger exhibited the overall best performance on renewable feedstocks. Therefore, it can be assumed that lignocellulosic hydrolysates from different feedstocks can be used as substrates for industrial fermentations and thus, upgrade the value of these feedstock wastes.

\section{Valorization of Olive Residues}

\subsection{Pretreatment of Olive Pomace and Leaves}

A common pretreatment process for olive residues is liquefaction. This procedure is similar to that described for potato peels (Sections 2.2 and 2.3). By liquefying or hydrolyzing olive residues, processing for further valorization is facilitated. Studies concerning the liquefaction of olive stones were published by Tejeda-Ricardez, et al. [348]. Liquefaction was performed using phenol (71 \% wt) and sulfuric acid $(6 \% \mathrm{wt})$ at $170{ }^{\circ} \mathrm{C}$ for $2 \mathrm{~h}$. The products were intended for use as raw material for phenol-formaldehyde resins. Similar, Briones, Serrano and Labidi [55] conducted a mild liquefaction of olive stones with polyhydric alcohols to obtain biopolyols. Liquefaction treatment of olive husks was also reported [349-351], whereas studies concerning the liquefaction of olive pomace are rather 
scarce [352]. Another pretreatment for valorization of olive wastes is aroma extraction. However, reports on the aroma extraction of olive residues are rare as they are more commonly used for extraction and application of polyphenols and pectins [353]. However, Reboredo-Rodríguez, et al. [354] described a method for the extraction of volatiles from olive samples based on dynamic headspace-thermal desorption (DHS-TD) combined with GC-MS. In another report this technique was used to extract aromatic compounds from olive pulp at an extraction temperature of $40^{\circ} \mathrm{C}$. By purging with an inert gas (helium), the volatiles were carried out and concentrated on a cooled trap [354,355]. However, these studies were not designed to use the aromatic compounds for further application but only for analysis and separation by GC.

Furthermore, disintegration of olive pomace and leaves is used to process these wastes. Steam explosion has been applied for wood since in the 1930's [356]. Nowadays it is still an important technology for treatment of woody biomass for biofuels production. In this context it is considered as an alternative for the much more intensive torrefaction of biomass, which takes place at higher temperatures and pressures [357]. Moreover, it is used to increase the extractability of phenolic acids, mainly ferulic acid from wheat bran [309]. In general, during application of steam explosion the biomass is exposed to direct steam for 30 seconds to 10 minutes and at pressures ranging from 130 to $220^{\circ} \mathrm{C}$. After a sudden pressure release the steam, which has penetrated within the biomass, expands and a large part of the plant infrastructure is destroyed, making the material more available for enzymatic hydrolysis. In this way enzymatic conversion of cellulose to glucose is improved. This results in high yields of woody biomass suitable for use as for example bio-based ethanol [358-360]. Some demonstration plants have been into operation but the technology has not reached full maturity yet. The effects of steam explosion are twofold: the short period of intense temperature and exposure to high pressure steam and water causes reactions to take place, such as hydrolysis of hemicellulose or the formation of furfural or similar substances. These reactions can be enhanced or slowed by addition of chemicals. For example, under alkali conditions lignin will be dissolved and the conversion rate of hemi-cellulose will be lower. Secondly, there is a disruption of the plant fibers due to the steam explosion. Both effects can improve the extraction of valuable compounds from the biomass. The destruction of plant structure can make certain molecules more available for dissolution by a solvent $[358,361]$.

Due to the fact that olive crops have to be cut down regularly during cultivation to achieve high yields (olive pruning), huge amounts of residues are generated. Depending on the culture conditions, 1 to 3 tons may arise per pruning process. The residues mainly consist of thin branches, leaves and wood, comprising cellulose, hemicellulose, lignin, minerals and extractives. Valuable compounds of that can be extracted from these residues include glucose, phenolics and other antioxidants [360,362-364]. Steam explosion is also considered as an effective pretreatment for obtaining valuable compounds from olive residues, including pomace and leaves [365,366]. Cara, et al. [360] applied steam explosion as a preparatory process for the use of olive residues, mainly olive wood as substrate for enzymatic hydrolysis. Furthermore, it was described that olive pomace treated with steam explosion is a good source of fermentable sugars [367]. Likewise, various phenolic compounds (e.g, vanillic acid, tyrosol, hydroxytyrosol) can be separated from olive stones and seed husks by steam explosion [368]. Therefore, steam explosion offers new opportunities for valorizing olive residues and might be a promising future technology.

Patent literature on pretreatment and olive oil waste processing is limited. The different components will probably behave differently in steam explosion: The pulp might have no significant benefit from this pretreatment. For olive stones and leaves it may be useful, but various conditions have to be applied. Washing and neutralization procedures are also important for the process steps downstream $[358,361]$. 


\subsection{Extraction and Purification of Phenolic Compounds from Olive Pomace and Leaves}

Olive pomace arises during olive oil production with $800 \mathrm{~kg} /$ ton olives and approximately 7 millions of tons per year in Europe. It is composed of skin, pulp, stone and olive kernels [369]. Since olive processing residues are rich in bioactive compounds especially phenolic acids, triterpenic acids and flavonoids, their extraction is highly desired and numerous application possibilities exist. By this means, huge amounts of olive residues which mainly accumulate in the Mediterranean areas can be valorized. Furthermore, the environmental issues might be reduced. Several methods for the extraction of phenolic compounds have been investigated, e.g., extraction with organic solvents, ultrasound- or microwave-assisted extraction and high-pressure processes [370-373]. Most commonly, solid/liquid extraction is used for plant materials whereby the extraction yield is dependent on the applied parameters. For example, the addition of water enhanced the polyphenol yield during extraction with ethanol [374-376]. Furthermore, an adjustment of the $\mathrm{pH}$ value to an alkaline milieu increased the extraction due to an improved solubility of the phenolic substances [377].

Polyphenols contained in olive pomace can be extracted under high pressure and incubation (25 bar, $180^{\circ} \mathrm{C}$ for $90 \mathrm{~min}$ ) with a mixture of ethanol: water $(50: 50 \mathrm{v} / \mathrm{v}$ ) resulting in yields of $5.77 \mathrm{mg}$ caffeic acid equivalents $/ \mathrm{mL}$ as measured by the Folin-Ciocalteu assay [378]. In contrast, the successive extraction of defatted olive pomace with chloroform, chloroform: methanol (9:1) and methanol resulted in 207-210 mg oleuropein equivalents/kg (Folin-Ciocalteu colorimetric method). Another procedure was described by Berthet, et al. [371] in which the milled olive pomace was mixed in a liquid ratio of 1:15 (w/w) with ethanol:water $(70: 30)$ and extracted at $80^{\circ} \mathrm{C}$ for $90 \mathrm{~min}$. The main phenolic compounds in olive pomace are oleuropein, ligstroside aglycone, tyrosol, oleuropein aglycone, caffeic and ferulic acid, depending on the cultivar [20]. For purification of the phenolic extracts, solid-phase extractions with silica-based C-18 cartridges can resulting in an increase in recovery of used up to $97-100 \%$ [379].

Olive leaves represent about $10 \%$ of the harvest weight and contain higher concentrations of antioxidants than the other parts of the plant [380,381]. Traditionally, polyphenols of olive leaves are extracted by maceration. However, the efficiency is rather low [382]. Therefore, several other extraction techniques have been investigated, e.g., solid liquid extraction (SLE), supercritical fluid extraction, pressurized liquid extraction, derivatized polar extraction, microwave assisted extraction and dynamic ultrasound assisted extraction [383-385]. Using SLE the best parameters for the extraction of phenolic compounds from olive leaves are often analyzed using response surface methodology. According to Sifaoui, et al. [386], an extraction with water at $58^{\circ} \mathrm{C}, \mathrm{pH} 8$ for $54 \mathrm{~min}$ and a liquid-to-solid ratio of 77:1 was most effective. The best conditions for an alcoholic extraction were published by Mkaouar, et al. [387] and are composed of $95.6 \%$ ethanol, $55^{\circ} \mathrm{C}$ and $40 \mathrm{ml} / \mathrm{g}$ dry matter. By applying an ultrasonic-assisted extraction at high temperatures, the polyphenol yield can be further improved [382]. The use of hydroalcoholic solvents, like methanol or ethanol-water mixtures have been investigated in detail, due to their ability to extract lipophilic as well as hydrophilic phenolic compounds [372,388]. The main phenolic substances in olive leaves have been identified using high performance liquid chromatography (HPLC) coupled with Photo Diode Array Detection (DAD) and studies have revealed that six major compounds are commonly present e.g., oleuropein, verbascoside, hydroxytyrosol, tyrosol, luteolin-7-O-glucoside and apigenin-7-O-glucoside [389-391].

The polyphenols present in olive oil processing chain by-products including olive leaves, olive pomace or olive oil mill wastes have found a variety of application potentials in the food market $[14,25,392,393]$. Polyphenols have recognized antioxidant activity $[19,43,44,394,395]$ and antimicrobial effects with protective effects against pathogenic agents [396-398]. Therefore, the use of olive waste products as an antioxidant or antimicrobial agent is promising. In addition, flavonoids have been linked to an enhancement of the antiviral activities [399]. The incorporation of polyphenol extracts such as gallic acid from waste waters of olive oil pomace has also been tested in enriched meat such as pre-cooked beef or pork to improve their lipid stability [400]. Moreover, polyphenols could be an interesting ingredient in the design of new beverages for their potential benefits on human health [401,402]. For instance, Kranz, et al. [403] evaluated fruit smoothies fortified with olive leaf 
extract containing high quantities of oleuropein and hydroxytyrosol. The study showed that at higher polyphenol levels $(20 \mathrm{mg} / 100 \mathrm{~g})$ the arising bitter taste can be reduced by addition of sodium cyclamate and sucrose.

\subsection{Purification of Olive Fibers}

The dietary fiber content of olives varies among the different cultivars, but is in general noticeable with 5-20 g/100 g total dietary fibers [404-406]. Almost one third of olive pulp cell walls consist of pectic polysaccharides with an esterification degree of more than $80 \%$. The soluble fraction is mainly composed of polyuronides and arabinans, the neutral fraction of arabinans with arabinose and the acid part of homogalacturonans and rhamnogalacturonans [405]. Olive endocarp is mostly lignified and contains high amounts of cellulose and hemicelluloses [407]. As olives are predominantly processed to oil by pressing, the residues of olive oil production are rich in dietary fibers. Olive pomace is composed of $65.3 \mathrm{wt} \%$ insoluble fibers and $5.5 \mathrm{wt} \%$ soluble fibers. Therefore, insoluble fibers represent the major fraction (approximately 92\%) with hemicellulose, cellulose and lignin being most abundant [408]. Due to their limited application, only a few refinery processes have been described. Valiente, et al. [409] used cellulases, hemicellulases and pectinolytic preparations to saccharify fibers of olive press cake and incorporated them in bakery goods. A prior treatment with chlorite improves the enzymatic hydrolysis [410]. Dufresne, et al. [367] used lignocellulosic flour of ground olive stones for the production of poly-(hydroxybutyrate-co-valerate, PHBV)-based composites and reported a significant reinforcing and a stabilization effect. Another study described the incorporation of olive husk flour into a polypropylene matrix [411]. The researchers observed an improved thermal stability of the composites. The fibers were purified by an extraction with methanol/water (90:10) for $12 \mathrm{~h}$ at room temperature to remove starch and waxes. Similar, an extraction of olive pomace with ethanol/water (70:30) for $90 \mathrm{~min}$ at $80{ }^{\circ} \mathrm{C}$ was applied to remove polyphenols [369]. This intended used of the extracted polyphenols was as anti-browning agent which can lead to the discoloration of some foods. Afterwards, the fibers were recovered by filtration and purified by an acid-alkaline fusion.

Besides their application as composites, fibers of olive cell wall can be extracted from olive mill by-products and used for the derivation of microcrystalline or powdered cellulose, as fat substitutes or gelling agents [366,406,412-414]. Pectic material of olive pomace, which could replace fat in confectionary has been obtained by extraction with nitric acid. Afterwards, the substrate was purified with chelating agents and recovered by an alcoholic precipitation with ethanol $[412,415]$. The extracted olive pectin exhibited a methylation degree of $42 \%$ and comparable rheological characteristics to citrus pectin.

The extraction of dietary fibers from olive mill wastewater was performed by ethanol and citric acid. Subsequently, ethanol was added to precipitate the alcohol insoluble residues. The isolated and concentrated water soluble fraction showed gel forming abilities [413].

\subsection{Production of Food Microorganisms Using Olive Mill Wastewaters}

Reports of the chemical composition of olive mill wastewaters (OMW) display large variations mainly due to the cultivar, harvesting time and extraction process [416]. The organic fraction of OMW is composed of sugars, organic acids, polyphenols and residual oil [417]. Polyphenols can exert antimicrobial or toxic effects against target microorganisms and thus, it is often not convenient to be contained in culture media. For this reason, OMW is often submitted to a chemical process in order to decrease its polyphenolic content. However, OMW has been investigated as a medium source for the production of single cell proteins and secondary metabolites. For example, solid fermentation of OMW by different Pleurotus species, S. cerevisiae, Kluyveromyces lactis, Oidodendron spp. and Penicillium spp. in order to produce microbial biomass and bioremediation has been investigated [418]. Aouidi, et al. [419] studied the production of Geotrichum candidum biomass, for its use as starter for cheese production using a combination of OMW enriched with cheese whey and found that the combination was a cost 
effective medium. OMW is also a good source of nutrients for the production of microbial protein from new isolated yeasts, e.g., Schwanniomyces etchellsiii M2 and Candida pararugosa BM24 [420].

Lipase production by Candida cylindracea on a supplemented OMW has been investigated by Brozzoli, et al. [416]. The production of citric acid by means of OMW fermentation using Yarrowia lipolytica strains has been also studied [417]. In this sense, Sarris, et al. [417] examined citric acid and biomass production of Yarrowia lipolytica on OMWs supplemented with sugar and nitrogen compounds and found efficient growth of different strains when cultivated on glucose-enriched OMWs. Moreover, polyphenols were reduced to $13-34 \%$ in all fermentations. Similar results were obtained by Papankolaou, et al. [421].

Solid wastes from the olive oil processing (waste pomace) have also been studied for solid state fermentation with the aim of providing a substrate for yeasts [422]. In this study, solid wastes were submitted to an alkaline pretreatment and to a delignification process by Phanerochaete chryosporium, Phlebia radiate, Pleurotus ostreatus or Dacrymyces stellatus. Subsequently, a saccharification by Trichoderma spp. was performed to provide substrates for Candida utilis or S. cerevisiae. A combination of these processes increased the concentration of crude protein in the pomace suggesting that it could be used for animal feed.

\section{Conclusions}

The ever-growing amount of agricultural and food wastes lead to the necessity to utilize these waste materials and to develop further processing technologies for their beneficial application. This review summarized the valorization potential and state-of-the-art technologies of agricultural and food waste products, especially of potato, tomato, cereals and olive. These materials exhibit considerable economic impact due to their high occurrence within the European Union. It was demonstrated that various valuable compounds can be extracted by different techniques from food wastes and by-products. Furthermore, numerous application possibilities were described. Nevertheless, the processes reported could be improved for example with regard to extraction yield, a reduce process labor and costs or the development of additional application opportunities. In addition it would be preferable to simplify and generalize the methods to increase the applicability. Therefore, further research and optimization studies on valorization technologies might be necessary with a recommendation to focus on full rather than laboratory studies to increase their relevance for industrial applications up-scaling from laboratory experiences.

Acknowledgments: This work was carried out in the framework of the AgriMax project (Valorization of agricultural residues and side streams from the agro-food industry), which is supported by the European Commission and has received funding from the Bio Based Industries Joint Undertaking under the European Union's Horizon 2020 research and innovation programme under the grant agreement No. 720719.

Author Contributions: Caroline Fritsch was the editor of the manuscript, main reviewer of formatting, contributing also to writing some sections about potato and olive processing and to integration of the different parts; Andreas Staebler defined the review structure and contributed also in writing and reviewing; Anton Happel wrote the chapter about the disintegration of olive residues; Miguel Angel Cubero Márquez contributed in describing the liquefaction and aroma extraction from potato and olive by-products; Ingrid Aguiló-Aguayo and Maribel Abadias contributed in writing sections about the production of food microorganisms using the different agricultural wastes; Miriam Gallur wrote the chapter about cellulose extraction from cereal processing residues; Ilaria Maria Cigognini and Angela Montanari contributed in writing the sections about lycopene and cutin extraction from tomato skins; Maria Jose López and Francisca Suárez-Estrella contributed in describing the fertilizer production from tomato processing residues; Nigel Brunton and Elisa Luengo revised the document linguistically and contributed in writing the section about the extraction of phenolic compounds from potato peels; Laura Sisti and Maura Ferri authored the sections about the extraction of biomoleculs from wheat bran; Gianluca Belotti contributed to the overall project management and also to writing the chapter about the ultrasound assisted extraction of toxic compounds from potato residues.

Conflicts of Interest: The authors declare no conflict of interest. The founding sponsors had no role in the design of the study; in the collection, analyses, or interpretation of data; in the writing of the manuscript, and in the decision to publish the results. 


\section{References}

1. Pawelczyk, A. Eu policy and legislation on recycling of organic wastes to agriculture. ISAH 2005, 1, 64-71.

2. Preparatory Study on Food Waste across EU 27. 2010. Available online: http:/ / ec.europa.eu/environment/ eussd/pdf/bio_foodwaste_report.pdf (accessed on 15 August 2017).

3. Food and Agriculture Organization of the United Nations. Food Loss and Food Waste. Available online: http: / / www.fao.org/food-loss-and-food-waste/en/ (accessed on 12 December 2016).

4. Mirabella, N.; Castellani, V.; Sala, S. Current options for the valorization of food manufacturing waste: A review. J. Clean. Prod. 2014, 65, 28-41. [CrossRef]

5. Integrated Product Policy: Building on Environmental Life-Cycle Thinking. 2003. Available online: http: / / eur-lex.europa.eu/legal-content/EN/TXT/?uri=CELEX:52003DC0302 (accessed on 9 March 2017).

6. A Resource-Efficient Europe-Flagship Initiative under the Europe 2020 Strategy. 2011. Available online: https: / www.eea.europa.eu/policy-documents/a-resource-efficient-europe-flagship (accessed on 15 August 2017).

7. European Commission. Innovating for Sustainable Growth: A Bioeconomy for Europe. 2012. Available online: https: / www.eea.europa.eu/policy-documents/innovating-for-sustainable-growth-a (accessed on 15 August 2017).

8. IndexMundi. Agricultural Production, Supply, and Distribution. Available online: http://www.indexmundi. com/ (accessed on 9 March 2017).

9. FAOSTAT Crops. Available online: http://www.fao.org/faostat/en/\#home (accessed on 9 March 2017).

10. Baiano, A. Recovery of biomolecules from food wastes-A review. Molecules 2014, 19, 14821-14842. [CrossRef] [PubMed]

11. Guil-Guerrero, J.L.; Ramos, L.; Moreno, C.; Zuniga-Paredes, J.C.; Carlosama-Yepez, M.; Ruales, P. Antimicrobial activity of plant-food by-products: A review focusing on the tropics. Livest. Sci. 2016, 189, 32-49. [CrossRef]

12. Kalogeropoulos, N.; Chiou, A.; Pyriochou, V.; Peristeraki, A.; Karathanos, V.T. Bioactive phytochemicals in industrial tomatoes and their processing byproducts. LWT Food Sci. Technol. 2012, 49, 213-216. [CrossRef]

13. Meuser, F.; Walther, G.; Dörfer, J. Design of a New Process for the Extraction of Soluble Beta-Glucan Products from Oat Bran. In Proceedings of the 3rd International Congress' Flour-Bread 05'and 5th Croatian Congress of Cereal Technologists, Opatija, Croatia, 26-29 October 2005; Faculty of Food Technology, University of Josip Juraj Strossmayer: Osijek, Croatia; pp. 153-161.

14. Gómez-Caravaca, A.M.; Verardo, V.; Bendini, A.; Toschi, T.G. From wastes to added value by-products: An overview on chemical composition and healthy properties of bioactive compounds of olive oil chain by-products. In Virgin Olive Oil: Production, Composition, Uses and Benefits for Man; De Leonardis, A., Ed.; Nova Science Publishers: New York, NY, USA, 2014; pp. 301-334.

15. Dordevic, T.; Antov, M. Wheat chaff utilization: Evaluation of antioxidant capacity of waste streams generated by different pretreatments. Ind. Crop Prod. 2016, 94, 649-657. [CrossRef]

16. Kong, K.W.; Khoo, H.E.; Prasad, K.N.; Ismail, A.; Tan, C.P.; Rajab, N.F. Revealing the power of the natural red pigment lycopene. Molecules 2010, 15, 959-987. [CrossRef] [PubMed]

17. Lazaridou, A.; Biliaderis, C.G. Molecular aspects of cereal beta-glucan functionality: Physical properties, technological applications and physiological effects. J. Cereal Sci. 2007, 46, 101-118. [CrossRef]

18. Perretti, G.; Miniati, E.; Montanari, L.; Fantozzi, P. Improving the value of rice by-products by sfe. J Supercrit. Fluid. 2003, 26, 63-71. [CrossRef]

19. Robles-Ramirez, M.D.; Monterrubio-Lopez, R.; Mora-Escobedo, R.; Beltran-Orozco, M.D. Evaluation of extracts from potato and tomato wastes as natural antioxidant additives. Arch. Latinoam. Nutr. 2016, 66, 66-73.

20. Cioffi, G.; Pesca, M.S.; De Caprariis, P.; Braca, A.; Severino, L.; De Tommasi, N. Phenolic compounds in olive oil and olive pomace from Cilento (Campania, Italy) and their antioxidant activity. Food Chem. 2010, 121, 105-111. [CrossRef]

21. Oruna-Concha, M.J.; Duckham, S.C.; Ames, J.H. Comparison of volatile compounds isolated from the skin and flesh of four potato cultivars after baking. J. Agric. Food Chem. 2001, 49, 2414-2421. [CrossRef] [PubMed]

22. Ties, P.; Barringer, S. Influence of lipid content and lipoxygenase on flavor volatiles in the tomato peel and flesh. J. Food Sci. 2012, 77, C830-C837. [CrossRef] [PubMed] 
23. Oreopoulou, V.; Tzia, C. Utilization of plant by-products for the recovery of proteins, dietary fibers, antioxidants, and colorants. In Utilization of By-Products and Treatment of Waste in the Food Industry; Springer: Berlin, Germany, 2007; pp. 209-232.

24. Sarkar, A.; Kaul, P. Evaluation of tomato processing by-products: A comparative study in a pilot scale setup. J. Food Process Eng. 2014, 37, 299-307. [CrossRef]

25. Gupta, P.; Ray, J.; Aggarwal, B.K.; Goyal, P. Good processing residue analysis and its functional components as related to human health: Recent developments. Austin J. Nutr. Food Sci. 2015, 3, 1068.

26. Nikkilä, M. Cereal Waste Valorization through Development of Functional Key Fibres to Innovate in Fibre Packaging Materials. Available online: http:/ / cordis.europa.eu/project/rcn/110025_en.html (accessed on 15 August 2017).

27. Mussatto, S.I.; Teixeira, J.A.; Ballesteros, L.F.; Martins, S. Use of agro-industrial wastes in solid-state fermentation processes. Ind. Waste 2012. [CrossRef]

28. Eco-Cycle. Waste of Energy-Why Incineration Is Bad for Our Economy, Environment and Community USA. Available online: https:/ / www.ecocycle.org/files/pdfs/WTE_wrong_for_environment_economy_ community_by_Eco-Cycle.pdf (accessed on 15 August 2017).

29. Ben Sghaier, M.; Skandrani, I.; Nasr, N.; Franca, M.-G.D.; Chekir-Ghedira, L.; Ghedira, K. Flavonoids and sesquiterpenes from tecurium ramosissimum promote antiproliferation of human cancer cells and enhance antioxidant activity: A structure-activity relationship study. Environ. Toxicol. Pharmacol. 2011, 32, 336-348. [CrossRef] [PubMed]

30. Leitzmann, C.; Müller, C.; Michel, P.; Brehme, U.; Triebel, T.; Hahn, A.; Laube, H. Ernährung in Prävention und Therapie—Ein Lehrbuch; Hippokrates: Stuttgart, Germany, 2009.

31. Meot-Duros, L.; Magné, C. Antioxidant activity and phenol content of Crithmum maritimum L. Leaves. Plant Physiol. Biochem. 2009, 47, 37-41. [CrossRef] [PubMed]

32. Watzl, B. Einfluss Sekundärer Pflanzenstoffe auf die Gesundheit; Deutsche Gesellschaft für Ernährung: Bonn, Germany, 2008; pp. 335-379.

33. Balasundram, N.; Sundram, K.; Samman, S. Phenolic compounds in plants and agri-industrial by-products: Antioxidant activity, occurrence, and potential uses. Food Chem. 2006, 99, 191-203. [CrossRef]

34. Wijngaard, H.H.; Ballay, M.; Brunton, N. The optimisation of extraction of antioxidants from potato peel by pressurised liquids. Food Chem. 2012, 133, 1123-1130. [CrossRef]

35. Al-Weshahy, A.; Rao, A.V. Isolation and characterization of functional components from peel samples of six potatoes varieties growing in Ontario. Food Res. Int. 2009, 42, 1062-1066. [CrossRef]

36. De Sotillo, D.R.; Hadley, M.; Holm, E.T. Potato peel waste-Stability and antioxidant activity of a freeze-dried extract. J. Food Sci. 1994, 59, 1031-1033. [CrossRef]

37. Tephly, T.R. The toxicity of methanol. Life Sci. 1991, 48, 1031-1041. [CrossRef]

38. NCBI. Pubchem Compound Database. Available online: https://pubchem.ncbi.nlm.nih.gov/compound/ 689043 (accessed on 31 January 2017).

39. Puertolas, E.; Cregenzan, O.; Luengo, E.; Alvarez, I.; Raso, J. Pulsed-electric-field-assisted extraction of anthocyanins from purple-fleshed potato. Food Chem. 2013, 136, 1330-1336. [CrossRef] [PubMed]

40. Samarin, A.M.; Poorazarang, H.; Hematyar, N.; Elhamirad, A. Phenolics in potato peels: Extraction and utilization as natural antioxidants. World Appl. Sci. J. 2012, 18, 191-195.

41. Pereira, R.N.; Rodrigues, R.M.; Genisheva, Z.; Oliveira, H.; de Freitas, V.; Teixeira, J.A.; Vicente, A.A. Effects of ohmic heating on extraction of food-grade phytochemicals from colored potato. LWT Food Sci. Technol. 2016, 74, 493-503. [CrossRef]

42. Singh, P.P.; Saldana, M.D.A. Subcritical water extraction of phenolic compounds from potato peel. Food Res. Int. 2011, 44, 2452-2458. [CrossRef]

43. Habeebullah, S.F.K.; Nielsen, N.S.; Jacobsen, C. Potato peel extracts: A potential antioxidant for omega-3enriched products. INFORM 2012, 23, 58-59.

44. De Sotillo, D.R.; Hadley, M.; Wolf-Hall, C. Potato peel extract a nonmutagenic antioxidant with potential antimicrobial activity. J. Food Sci. 1998, 63, 907-910. [CrossRef]

45. Viscidi, K.A.; Dougherty, M.P.; Briggs, J.; Camire, M.E. Complex phenolic compounds reduce lipid oxidation in extruded oat cereals. LWT Food Sci. Technol. 2004, 37, 789-796. [CrossRef] 
46. Amado, I.R.; Franco, D.; Sanchez, M.; Zapata, C.; Vazquez, J.A. Optimisation of antioxidant extraction from solanum tuberosum potato peel waste by surface response methodology. Food Chem. 2014, 165, 290-299. [CrossRef] [PubMed]

47. Singh, A.; Sabally, K.; Kubow, S.; Donnelly, D.J.; Gariepy, Y.; Orsat, V.; Raghavan, G.S.V. Microwave-assisted extraction of phenolic antioxidants from potato peels. Molecules 2011, 16, 2218-2232. [CrossRef] [PubMed]

48. Mohdaly, A.A.A.; Hassanien, M.F.R.; Mahmoud, A.; Sarhan, M.A.; Smetanska, I. Phenolics extracted from potato, sugar beet, and sesame processing by-products. Int. J. Food Prop. 2013, 16, 1148-1168. [CrossRef]

49. Arapoglou, D.; Varzakas, T.; Vlyssides, A.; Israilides, C. Ethanol production from potato peel waste (PPW). Waste Manag. 2010, 30, 1898-1902. [CrossRef] [PubMed]

50. Yamada, S.; Shinomiya, N.; Ohba, K.; Sekikawa, M.; Oda, Y. Enzymatic hydrolysis and ethanol fermentation of by-products from potato processing plants. Food Sci. Technol. Res. 2009, 15, 653-658. [CrossRef]

51. Ventura, P.; Bordado, J.C.M.; Mateus, M.M.; Galhano dos Santos, R. Upcycling potato peel waste-Data of the pre-screening of the acid-catalyzed liquefaction. Data Brief 2016, 7, 1455-1457. [CrossRef] [PubMed]

52. Mateus, M.M.; Ventura, P.; Rego, A.; Mota, C.; Castanheira, I.; Bordado, J.; dos Santos, R.G. Acid liquefaction of potato (Solanum tuberosum) and sweet potato (Ipomoea batatas) cultivars peels-pre-screening of antioxidant activity/total phenolic and sugar contents. BioResources 2017, 12, 1463-1478. [CrossRef]

53. Israilides, C.; Vlyssides, A.; Arapoglou, D.; Varzakas, T.; Marchant, R.; Vlysides, A. Integrated management of potato starch wastes. In Waste 2008: Waste and Resource Management-A Shared Responsibility; Marie, T., Ed.; Waste Conference Ltd.: Stratford, UK, 2008.

54. Sánchez, Ó.J.; Cardona, C.A. Trends in biotechnological production of fuel ethanol from different feedstocks. Bioresour. Technol. 2008, 99, 5270-5295. [CrossRef] [PubMed]

55. Briones, R.; Serrano, L.; Labidi, J. Valorization of some lignocellulosic agro-industrial residues to obtain biopolyols. J. Chem. Technol. Biotechnol. 2012, 87, 244-249. [CrossRef]

56. Abdelmoez, W.; Nage, S.M.; Bastawess, A.; Ihab, A.; Yoshida, H. Subcritical water technology for wheat straw hydrolysis to produce value added products. J. Clean. Prod. 2014, 70, 68-77. [CrossRef]

57. Karagöz, S.; Bhaskar, T.; Muto, A.; Sakata, Y.; Uddin, M.A. Low-temperature hydrothermal treatment of biomass: Effect of reaction parameters on products and boiling point distributions. Energy Fuels 2004, 18, 234-241. [CrossRef]

58. Nagamori, M.; Funazukuri, T. Glucose production by hydrolysis of starch under hydrothermal conditions. J. Chem. Technol. Biotechnol. 2004, 79, 229-233. [CrossRef]

59. Yin, S.; Tan, Z. Hydrothermal liquefaction of cellulose to bio-oil under acidic, neutral and alkaline conditions. Appl. Energy 2012, 92, 234-239. [CrossRef]

60. Li, F.; Liu, L.; An, Y.; He, W.; Themelis, N.J.; Li, G. Hydrothermal liquefaction of three kinds of starches into reducing sugars. J. Clean. Prod. 2016, 112, 1049-1054. [CrossRef]

61. Teranishi, R.; Kint, S. Bioactive Volatile Compounds from Plants: An Overview. Available online: http: / / agris.fao.org/agris-search/search.do?recordID=US9437272 (accessed on 15 August 2017).

62. Galego, L.R.; Da Silva, J.P.; Almeida, V.R.; Bronze, M.R.; Boas, L.V. Preparation of novel distinct highly aromatic liquors using fruit distillates. Int. J. Food Sci. Technol. 2011, 46, 67-73. [CrossRef]

63. Gounaris, Y. Biotechnology for the production of essential oils, flavours and volatile isolates. A review. Flavour Fragr. J. 2010, 25, 367-386. [CrossRef]

64. Franz, S.; Willersinn, D.; Kroschel, K. Evaluating sensor effects on perception performance. In Proceedings of the IEEE Intelligent Vehicles Symposium, San Diego, CA, USA, 21-24 June 2010; pp. 634-639.

65. Flavourtech. Spinning Cone Column. Available online: http://flavourtech.com/products/spinning-conecolumn/ (accessed on 30 January 2017).

66. Buttery, R.G.; Guadagni, D.G.; Ling, L.C. Volatile components of baked potatoes. J. Sci. Food Agric. 1973, 24, 1125-1131. [CrossRef]

67. Center, I.P. Potato Facts and Figures. Available online: http://cipotato.org/potato/facts/ (accessed on 8 February 2017).

68. Schieber, A.; Saldaña, M.D.A. Potato peels: A source of nutritionally and pharmacologically interesting compounds-A review. Food 2009, 3, 23-29.

69. Austin, S.; Lojkowska, E.; Ehlenfeldt, K.; Kelman, A.; Helgeson, J.P. Fertile interspecific somatic hybrids of solanum: A novel source of resistance to erwinia soft rot. Phytopathology 1988, 78, 1216-1220. [CrossRef] 
70. Fewell, A.M.; Roddick, J.G. Interactive antifungal activity of the glycoalkaloids alpha-solanine and alpha-chaconine. Phytochemistry 1993, 33, 323-328. [CrossRef]

71. Sanford, L.L.; Kobayashi, R.S.; Deahl, K.L.; Sinden, S.L. Diploid and tetraploid solanum chacoense genotypes that synthesize leptine glycoalkaloids and deter feeding by colorado potato beetle. Am. Potato J. 1997, 74, 15-21. [CrossRef]

72. Morris, S.C.; Lee, T.H. The toxicity and teratogenicity of Solanaceae glycoalkaloids, particularly those of the potato (Solanum-tuberosum) -A review. Food Technol. Aust. 1984, 36, 118-124.

73. Slanina, P. Solanine (glycoalkaloids) in potatoes-Toxicological evaluation. Food Chem. Toxicol. 1990, 28, 759-761. [CrossRef]

74. Friedman, M.; McDonald, G.M. Postharvest changes in glycoalkaloid content of potatoes. In Impact of Processing on Food Safety; Jackson, L.S., Knize, M.G., Morgan, J.N., Eds.; Springer: Boston, MA, USA, 1999; pp. 121-143.

75. Ripperger, H. Chapter two-Solanum steroid alkaloids-An update. In Alkaloids: Chemical and Biological Perspectives; Pelletier, S.W., Ed.; John Wiley and Sons: New York, NY, USA, 1998; Volume 12, pp. 103-185.

76. Friedman, M. Potato glycoalkaloids and metabolites: Roles in the plant and in the diet. J. Agric. Food Chem. 2006, 54, 8655-8681. [CrossRef] [PubMed]

77. Weissenberg, M.; Levy, A.; Svoboda, J.A.; Ishaaya, I. The effect of some solanum steroidal alkaloids and glycoalkaloids on larvae of the red flour beetle, tribolium castaneum, and the tobacco hornworm, manduca sexta. Phytochemistry 1998, 47, 203-209. [CrossRef]

78. McGehee, D.S.; Krasowski, M.D.; Fung, D.L.; Wilson, B.; Gronert, G.A.; Moss, J. Cholinesterase inhibition by potato glycoalkaloids slows mivacurium metabolism. ASA 2000, 93, 510-519. [CrossRef]

79. Michalska, L.; Nagel, G.; Swiniarski, E.; Żydowo, M.M. The effect of $\alpha$-solanine on the active calcium transport in rat intestine. Gen. Pharmacol. Vasc. Syst. 1985, 16, 69-70. [CrossRef]

80. Blankemeyer, J.T.; Atherton, R.; Friedman, M. Effect of potato glycoalkaloids Alpha-chaconine and Alpha-solanine on sodium active transport in frog skin. J. Agric. Food Chem. 1995, 43, 636-639. [CrossRef]

81. Toyoda, M.; Rausch, W.D.; Inoue, K.; Ohno, Y.; Fujiyama, Y.; Takagi, K.; Saito, Y. Comparison of solanaceous glycoalkaloids-evoked $\mathrm{Ca}^{2+}$ influx in different types of cultured cells. Toxicol. In Vitro 1991, 5, 347-351. [CrossRef]

82. Romanucci, V.; Pisanti, A.; Di Fabio, G.; Davinelli, S.; Scapagnini, G.; Guaragna, A.; Zarrelli, A. Toxin levels in different variety of potatoes: Alarming contents of $\alpha$-chaconine. Phytochem. Lett. 2016, 16, 103-107. [CrossRef]

83. Phillips, B.J.; Hughes, J.A.; Phillips, J.C.; Walters, D.G.; Anderson, D.; Tahourdin, C.S.M. A study of the toxic hazard that might be associated with the consumption of green potato tops. Food Chem. Toxicol. 1996, 34, 439-448. [CrossRef]

84. Hossain, M.B.; Rai, D.K.; Brunton, N.P. Optimisation and validation of ultra-high performance liquid chromatographic-tandem mass spectrometry method for qualitative and quantitative analysis of potato steroidal alkaloids. J. Chrom. B 2015, 997, 110-115. [CrossRef] [PubMed]

85. Chang, K. Polyphenol Antioxidants from Potato Peels: Extraction Optimization and Application to Stabilizing Lipid Oxidation in Foods. In Proceedings of the National Conference on Undergraduate Research (NCUR), New York, NY, USA, 30 March-2 April 2011.

86. Glisic, S.B.; Ristic, M.; Skala, D.U. The combined extraction of sage (Salvia officinalis L.): Ultrasound followed by supercritical $\mathrm{CO}_{2}$ extraction. Ultrason. Sonochem. 2011, 18, 318-326. [CrossRef] [PubMed]

87. Vinatoru, M. An overview of the ultrasonically assisted extraction of bioactive principles from herbs. Ultrason. Sonochem. 2001, 8, 303-313. [CrossRef]

88. Wijngaard, H.; Hossain, M.B.; Rai, D.K.; Brunton, N. Techniques to extract bioactive compounds from food by-products of plant origin. Food Res. Int. 2012, 46, 505-513. [CrossRef]

89. Мa, Y.; Ye, X.; Hao, Y.; Xu, G.; Xu, G.; Liu, D. Ultrasound-assisted extraction of hesperidin from penggan (Citrus reticulata) peel. Ultrason. Sonochem. 2008, 15, 227-232. [CrossRef] [PubMed]

90. Veličković, D.T.; Milenović, D.M.; Ristić, M.S.; Veljković, V.B. Ultrasonic extraction of waste solid residues from the Salvia sp. essential oil hydrodistillation. Biochem. Eng. J. 2008, 42, 97-104. [CrossRef]

91. Virot, M.; Tomao, V.; Le Bourvellec, C.; Renard, C.M.C.G.; Chemat, F. Towards the industrial production of antioxidants from food processing by-products with ultrasound-assisted extraction. Ultrason. Sonochem. 2010, 17, 1066-1074. [CrossRef] [PubMed] 
92. Chemat, F.; Rombaut, N.; Sicaire, A.G.; Meullemiestre, A.; Fabiano-Tixier, A.S.; Abert-Vian, M. Ultrasound assisted extraction of food and natural products. Mechanisms, techniques, combinations, protocols and applications. A review. Ultrason. Sonochem. 2017, 34, 540-560. [CrossRef] [PubMed]

93. Mason, T.J. Sonochemistry and sonoprocessing: The link, the trends and (probably) the future. Ultrason. Sonochem. 2003, 10, 175-179. [CrossRef]

94. Toma, M.; Vinatoru, M.; Paniwnyk, L.; Mason, T.J. Investigation of the effects of ultrasound on vegetal tissues during solvent extraction. Ultrason. Sonochem. 2001, 8, 137-142. [CrossRef]

95. Tang, D.-M.; Zhu, C.-F.; Zhong, S.-A.; Zhou, M.-D. Extraction of naringin from pomelo peels as dihydrochalcone's precursor. J. Separ. Sci. 2011, 34, 113-117. [CrossRef] [PubMed]

96. Vilkhu, K.; Mawson, R.; Simons, L.; Bates, D. Applications and opportunities for ultrasound assisted extraction in the food industry-A review. Innov. Food Sci. Emerg. Technol. 2008, 9, 161-169. [CrossRef]

97. Pingret, D.; Fabiano-Tixier, A.S.; Chemat, F. Ultrasound-assisted extraction. In Natural Product Extraction: Principles and Applications; Rostagno, M.A., Prado, J.M., Eds.; Royal Society of Chemistry: London, UK, 2013; pp. 89-112.

98. Vinatoru, M. Ultrasonically assisted extraction (UAE) of natural products some guidelines for good practice and reporting. Ultrason. Sonochem. 2015, 25, 94-95. [CrossRef] [PubMed]

99. Gallego-Juarez, J.A. High-power ultrasonic processing: Recent developments and prospective advances. Phys. Procedia 2010, 3, 35-47. [CrossRef]

100. Qiyun, S.; Liang, Q. Study on the production of SCP feed from potato mash residue. Cereal Feed Ind. 2004, 9 , 32-33.

101. Jianmin, Yun. Study on production of SCP feed from potato residue. J. Microbiol. 1998, 19, $23-27$.

102. Gharsallah, N. Production of single cell protein from olive mill waste water by yeasts. Environ. Technol. 1993, 14, 391-395. [CrossRef]

103. Schultz, N.; Chang, L.; Hauck, A.; Reuss, M.; Syldatk, C. Microbial production of single-cell protein from deproteinized whey concentrates. Appl. Microbiol. Biotechnol. 2006, 69, 515-520. [CrossRef] [PubMed]

104. Moon, N.J.; Hammond, E.G.; Glatz, B.A. Conversion of cheese whey and whey permeate to oil and single-cell protein1. J. Dairy Sci. 1978, 61, 1537-1547. [CrossRef]

105. Nigam, P.; Vogel, M. Bioconversion of sugar industry by-products-Molasses and sugar beet pulp for single cell protein production by yeasts. Biomass Bioenergy 1991, 1, 339-345. [CrossRef]

106. Tanaka, M.; Matsuno, R. Conversion of lignocellulosic materials to single-cell protein (SCP): Recent developments and problems. Enzym. Microb. Technol. 1985, 7, 197-206. [CrossRef]

107. Kavšček, M.; Stražar, M.; Curk, T.; Natter, K.; Petrovič, U. Yeast as a cell factory: Current state and perspectives. Microb. Cell Fact. 2015, 14, 1. [CrossRef] [PubMed]

108. Rumbold, K.; van Buijsen, H.J.J.; Overkamp, K.M.; van Groenestijn, J.W.; Punt, P.J.; van der Werf, M.J. Microbial production host selection for converting second-generation feedstocks into bioproducts. Microb. Cell Fact. 2009. [CrossRef] [PubMed]

109. Ostergaard, S.; Olsson, L.; Nielsen, J. Metabolic engineering of Saccharomyces cerevisiae. Microbiol. Mol. Biol. Rev. 2000, 64, 34-50. [CrossRef] [PubMed]

110. Altıntaş, M.M.; Ülgen, K.Ö.; Kırdar, B.; Önsan, Z.İ.; Oliver, S.G. Optimal substrate feeding policy for fed-batch cultures of $\mathrm{S}$. cerevisiae expressing bifunctional fusion protein displaying amylolytic activities. Enzym. Microb. Technol. 2003, 33, 262-269. [CrossRef]

111. Bacha, U.; Nasir, M.; Khalique, A.; Anjum, A.A.; Jabbar, M.A. Comparative assessment of various agro-industrial wastes for saccharomyces cerevisiae biomass production and its quality evaluation as single cell protein. J. Anim. Plant Sci. 2011, 21, 844-849.

112. Chang, M.; Zhou, S.G.; Lu, N.; Ni, J.R. Starch processing wastewater as a new medium for production of bacillus thuringiensis. World J. Microbiol. Biotechnol. 2008, 24, 441-447. [CrossRef]

113. Srisamai, S.; Srikhampa, P.; Pathom-aree, W. Production of probiotic streptomyces biomass from starchy wastewater. Chiang Mai J. Sci. 2013, 40, 294-298.

114. Calleja, G.B.; Yaguchi, M.; Levy-Rick, S.; Seguin, J.R.H.; Roy, C.; Lusena, C.V. Single-cell protein production from potato starch by the yeast schwanniomyces alluvius. J. Ferment. Technol. 1986, 64, 71-75. [CrossRef]

115. Kleekayai, T.; Suntornsuk, W. Production and characterization of chitosan obtained from rhizopus oryzae grown on potato chip processing waste. World J. Microbiol. Biotechnol. 2011, 27, 1145-1154. [CrossRef] 
116. Izmirlioglu, G.; Demirci, A. Strain selection and medium optimization for glucoamylase production from industrial potato waste by aspergillus Niger. J. Sci. Food Agric. 2016, 96, 2788-2795. [CrossRef] [PubMed]

117. Pagana, I.; Morawicki, R.; Hager, T.J. Lactic acid production using waste generated from sweet potato processing. Int. J. Food Sci. Technol. 2014, 49, 641-649. [CrossRef]

118. Fox, S.L.; Bala, G.A. Production of surfactant from bacillus subtilis atcc 21332 using potato substrates. Bioresour. Technol. 2000, 75, 235-240. [CrossRef]

119. Wojnowska, I.; Poznanski, S.; Bednarski, W. Processing of potato protein-concentrates and their properties. J. Food Sci. 1982, 47, 167-172. [CrossRef]

120. Waglay, A.; Karboune, S. Enzymatic generation of peptides from potato proteins by selected proteases and characterization of their structural properties. Biotechnol. Progr. 2016, 32, 420-429. [CrossRef] [PubMed]

121. Zwijnenberg, H.J.; Kemperman, A.J.B.; Boerrigter, M.E.; Lotz, M.; Dijksterhuis, J.F.; Poulsen, P.E.; Koops, G.-H. Native protein recovery from potato fruit juice by ultrafiltration. Desalination 2002, 144, 331-334. [CrossRef]

122. Knorr, D.; Kohler, G.; Betschart, A. Potato protein concentrates: The influence of various methods of recovery upon yield, compositional and functional characteristics. J. Food Process. Preserv. 1977, 1, 235-247. [CrossRef]

123. Graf, A.M.; Steinhof, R.; Lotz, M.; Tippkötter, N.; Kasper, C.; Beutel, S.; Ulber, R. Downstream-processing mit membranadsorbern zur isolierung nativer proteinfraktionen aus kartoffelfruchtwasser. Chem. Ing. Tech. 2009, 81, 267-274. [CrossRef]

124. Alt, V.; Steinhof, R.; Lotz, M.; Ulber, R.; Kasper, C.; Scheper, T. Optimization of glycoalkaloid analysis for use in industrial potato fruit juice downstreaming. Eng. Life Sci. 2005, 5, 562-567. [CrossRef]

125. Van Koningsveld, G.A.; Walstra, P.; Voragen, A.G.J.; Kuijpers, I.J.; Van Boekel, M.A.J.S.; Gruppen, H. Effects of protein composition and enzymatic activity on formation and properties of potato protein stabilized emulsions. J. Agric. Food Chem. 2006, 54, 6419-6427. [CrossRef] [PubMed]

126. Bartova, V.; Barta, J.; Brabcova, A.; Zdrahal, Z.; Horackova, V. Amino acid composition and nutritional value of four cultivated south american potato species. J. Food Compos. Anal. 2015, 40, 78-85. [CrossRef]

127. Bártová, V.; Bárta, J. Chemical composition and nutritional value of protein concentrates isolated from potato (Solanum tuberosum L.) fruit juice by precipitation with ethanol or ferric chloride. J. Agric. Food Chem. 2009, 57, 9028-9034. [CrossRef] [PubMed]

128. Creusot, N.; Wierenga, P.A.; Laus, M.C.; Giuseppin, M.L.; Gruppen, H. Rheological properties of patatin gels compared with $\beta$-lactoglobulin, ovalbumin, and glycinin. J. Agric. Food Chem. 2011, 91, 253-261. [CrossRef] [PubMed]

129. Kudo, K.; Onodera, S.; Takeda, Y.; Benkeblia, N.; Shiomi, N. Antioxidative activities of some peptides isolated from hydrolyzed potato protein extract. J. Funct. Foods 2009, 1, 170-176. [CrossRef]

130. Bergthaller, W.; Witt, W.; Goldau, H.P. Potato starch technology. Starch Stärke 1999, 51, 235-242. [CrossRef]

131. Kinsella, J.E.; Melachouris, N. Functional properties of proteins in foods: A survey. CRC Crit. Rev. Food Sci. Nutr. 1976, 7, 219-280. [CrossRef]

132. Knorr, D. Protein quality of potato and potato protein-concentrates. Lebensm.Wiss. Technol. 1978, 11, $109-115$.

133. Boruch, M.; Makowski, J.; Wachowicz, M.; Dubla, W. Rückgewinnung der stickstoffverbindungen aus kartoffelfruchtwasser. Food Nahrung 1989, 33, 67-76. [CrossRef]

134. Edens, L.; Van der Lee, J.A.B.; Plijter, J.J. Novel Food Compositions. Patent EP0912105 A1, 12 May 1997.

135. Van Koningsveld, G.A.; Gruppen, H.; de Jongh, H.H.J.; Wijngaards, G.; van Boekel, M.A.J.S.; Walstral, P.; Voragen, A.G.J. The solubility of potato proteins from industrial potato fruit juice as influenced by $\mathrm{pH}$ and various additives. J. Sci. Food Agric. 2002, 82, 134-142. [CrossRef]

136. Gonzalez, J.M.; Lindamood, J.B.; Desai, N. Recovery of protein from potato plant waste effluents by complexation with carboxymethylcellulose. Food Hydrocoll. 1991, 4, 355-363. [CrossRef]

137. Lindner, P.; Keren, R.; Bengera, I. Precipitation of proteins from potato juice with bentonite. J. Sci. Food Agric. 1981, 32, 1177-1182. [CrossRef] [PubMed]

138. Knorr, D. Effect of recovery methods on yield, quality and functional-properties of potato protein-concentrates. J. Food Sci. 1980, 45, 1183-1186. [CrossRef]

139. Knorr, D. Effect of recovery methods on the functionality of vegetable proteins. J. Am. Oil Chem. Soc. 1982, 59, A302.

140. Meister, E.; Thompson, N.R. Physical-chemical methods for recovery of protein from waste effluent of potato-chip processing. J. Agric. Food Chem. 1976, 24, 919-923. [CrossRef] 
141. Kamnerdpetch, C.; Weiss, M.; Kasper, C.; Scheper, T. An improvement of potato pulp protein hydrolyzation process by the combination of protease enzyme systems. Enzym. Microb. Technol. 2007, 40, 508-514. [CrossRef]

142. Cheng, Y.; Xiong, Y.L.L.; Chen, J. Fractionation, separation, and identification of antioxidative peptides in potato protein hydrolysate that enhance oxidative stability of soybean oil emulsions. J. Food Sci. 2010, 75, C760-C765. [CrossRef] [PubMed]

143. Miedzianka, J.; Peksa, A.; Pokora, M.; Rytel, E.; Tajner-Czopek, A.; Kita, A. Improving the properties of fodder potato protein concentrate by enzymatic hydrolysis. Food Chem. 2014, 159, 512-518. [CrossRef] [PubMed]

144. Dabestani, S.; Arcot, J.; Chen, V. Protein recovery from potato processing water: Pre-treatment and membrane fouling minimization. J. Food Eng. 2017, 195, 85-96. [CrossRef]

145. Talburt, W.F.; Smith, O. Potato Processing; AVI Publishing Company: Westport, CT, USA, 1975.

146. Reboul, E.; Borel, P.; Mikail, C.; Abou, L.; Charbonnier, M.; Caris-Veyrat, C.; Goupy, P.; Portugal, H.; Lairon, D.; Amiot, M.J. Enrichment of tomato paste with $6 \%$ tomato peel increases lycopene and $\beta$-carotene bioavailability in men. J. Nutr. 2005, 135, 790-794. [PubMed]

147. Mayer, F. Potato pulp: Properties, physical modification and applications. Polym. Degrad. Stab. 1998, 59, 231-235. [CrossRef]

148. Kempf, W. Beitrag zur mechanischen entwässerung von kartoffelpülpe. Starch-Stärke 1980, 32, 14-20. [CrossRef]

149. Hillebrandt, J.-O. Kartoffelpülpe, ein Landwirtschaftliches Abfallprodukt und ein Nachwachsender Rohstoff: Versuche zu Ihrer Mikrobiologischen Charakterisierung, Ihrer Konservierung und Ihrem Abbau; Cuvillier: Göttingen, Germany, 1994.

150. Lisinska, G.; Leszczynski, W. Potato Science and Technology; Springer Science \& Business Media: Berlin, Germany, 1989.

151. Tegge, G. Stärke und Stärkederivate; Behr's Verlag: Hamburg, Germany, 2004.

152. Slomińska, L.; Starogardzka, G. Application of a multi-enzyme complex in the utilization of potato pulp. Starch-Stärke 1987, 39, 121-125. [CrossRef]

153. Waglay, A.; Karboune, S. A novel enzymatic approach based on the use of multi-enzymatic systems for the recovery of enriched protein extracts from potato pulp. Food Chem. 2017, 220, 313-323. [CrossRef] [PubMed]

154. Abousteit, O.; Kempf, W. Pektingewinnung aus kartoffelpülpe und ihre mögliche bedeutung für die kartoffelstärkeindustrie. Starch-Stärke 1974, 26, 417-421. [CrossRef]

155. Turquois, T.; Rinaudo, M.; Taravel, F.R.; Heyraud, A. Extraction of highly gelling pectic substances from sugar beet pulp and potato pulp: Influence of extrinsic parameters on their gelling properties. Food Hydrocoll. 1999, 13, 255-262. [CrossRef]

156. Klingspohn, U.; Bader, J.; Kruse, B.; Vijai Kishore, P.; Schügerl, K.; Kracke-Helm, H.A.; Likidis, Z. Utilization of potato pulp from potato starch processing. Process Biochem. 1993, 28, 91-98. [CrossRef]

157. Khodaei, N.; Karboune, S.; Orsat, V. Microwave-assisted alkaline extraction of galactan-rich rhamnogalacturonan i from potato cell wall by-product. Food Chem. 2016, 190, 495-505. [CrossRef] [PubMed]

158. Batista, J.E.R.; Demorais, M.P.; Caliari, M.; Soares, M.S.J. Physical, microbiological and sensory quality of gluten-free biscuits prepared from rice flour and potato pulp. J. Food Nutr. Res. 2016, 55, 101-107.

159. Obidziński, S. Analysis of usability of potato pulp as solid fuel. Fuel Process. Technol. 2012, 94, 67-74. [CrossRef]

160. Ercolano, M.R.; Gomez, L.D.; Andolfi, A.; Simister, R.; Troise, C.; Angelino, G.; Borrelli, C.; McQueen-Mason, S.J.; Evidente, A.; Frusciante, L.; et al. Residual biomass saccharification in processing tomato is affected by cultivar and nitrogen fertilization. Biomass Bioenerg 2015, 72, 242-250. [CrossRef]

161. Shrestha, N.; Fogg, A.; Wilder, J.; Franco, D.; Komisar, S.; Gadhamshetty, V. Electricity generation from defective tomatoes. Bioelectrochemistry 2016, 112, 67-76. [CrossRef] [PubMed]

162. Ventura, M.R.; Pieltain, M.C.; Castanon, J.I.R. Evaluation of tomato crop by-products as feed for goats. Anim. Feed Sci. Technol. 2009, 154, 271-275. [CrossRef]

163. Lenucci, M.S.; Leucci, M.R.; Piro, G.; Dalessandro, G. Variability in the content of soluble sugars and cell wall polysaccharides in red-ripe cherry and high-pigment tomato cultivars. J. Sci. Food Agric. 2008, 88, 1837-1844. [CrossRef] 
164. Riggi, E.; Avola, G. Fresh tomato packinghouses waste as high added-value biosource. Resour. Conserv. Recyl. 2008, 53, 96-106. [CrossRef]

165. Bacenetti, J.; Duca, D.; Negri, M.; Fusi, A.; Fiala, M. Mitigation strategies in the agro-food sector: The anaerobic digestion of tomato puree by-products. An Italian case study. Sci. Total Environ. 2015, 526, 88-97. [CrossRef] [PubMed]

166. Riggi, E.; Avola, G. Quantification of the waste stream from fresh tomato packinghouses and its fluctuations: Implications for waste management planning. Resour. Conserv. Recyl. 2010, 54, 436-441. [CrossRef]

167. Ribaudo, M.O.; Gollehon, N.R.; Agapoff, J. Land application of manure by animal feeding operations: Is more land needed? J. Soil Water Conserv. 2003, 58, 30-38.

168. Ayalon, O.; Avnimelech, Y.; Shechter, M. Solid waste treatment as a high-priority and low-cost alternative for greenhouse gas mitigation. Environ. Manag. 2001, 27, 697-704.

169. Ravindran, R.; Jaiswal, A.K. Exploitation of food industry waste for high-value products. Trends Biotechnol. 2016, 34, 58-69. [CrossRef] [PubMed]

170. Jurado, M.M.; Suarez-Estrella, F.; Lopez, M.J.; Vargas-Garcia, M.C.; Lopez-Gonzalez, J.A.; Moreno, J. Enhanced turnover of organic matter fractions by microbial stimulation during lignocellulosic waste composting. Bioresour. Technol. 2015, 186, 15-24. [CrossRef] [PubMed]

171. Lopez-Gonzalez, J.A.; Lopez, M.J.; Vargas-Garcia, M.C.; Suarez-Estrella, F.; Jurado, M.; Moreno, J. Tracking organic matter and microbiota dynamics during the stages of lignocellulosic waste composting. Bioresour. Technol. 2013, 146, 574-584. [CrossRef] [PubMed]

172. Sheets, J.P.; Yang, L.; Ge, X.; Wang, Z.; Li, Y. Beyond land application: Emerging technologies for the treatment and reuse of anaerobically digested agricultural and food waste. Waste Manag. 2015, 44, 94-115. [CrossRef] [PubMed]

173. Sweeten, J.M. Composting Manure and Sludge. Available online: http://hdl.handle.net/1969.1/87650 (accessed on 15 August 2017).

174. Kalamdhad, A.S.; Singh, Y.K.; Ali, M.; Khwairakpam, M.; Kazmi, A.A. Rotary drum composting of vegetable waste and tree leaves. Bioresour. Technol. 2009, 100, 6442-6450. [CrossRef] [PubMed]

175. Suluk, K.; Tosun, I.; Ekinci, K. Co-composting of two-phase olive-mill pomace and poultry manure with tomato harvest stalks. Environ. Technol. 2017, 38, 923-932. [CrossRef] [PubMed]

176. Sevik, F.; Tosun, I.; Ekinci, K. Composting of olive processing wastes and tomato stalks together with sewage sludge or dairy manure. Int. J. Environ. Sci. Technol. 2016, 13, 1207-1218. [CrossRef]

177. Vargas-Garcia, M.C.; Suarez-Estrella, F.; Lopez, M.J.; Moreno, J. Microbial population dynamics and enzyme activities in composting processes with different starting materials. Waste Manag. 2010, 30, 771-778. [CrossRef] [PubMed]

178. Lopez-Gonzalez, J.A.; Suarez-Estrella, F.; Vargas-Garcia, M.C.; Lopez, M.J.; Jurado, M.M.; Moreno, J. Dynamics of bacterial microbiota during lignocellulosic waste composting: Studies upon its structure, functionality and biodiversity. Bioresour. Technol. 2015, 175, 406-416. [CrossRef] [PubMed]

179. Liu, W.; Wang, S.T.; Zhang, J.; Xu, T. Biochar influences the microbial community structure during tomato stalk composting with chicken manure. Bioresour. Technol. 2014, 154, 148-154.

180. Kulcu, R. Composting of greenhouse tomato plant residues, wheat straw, and separated dairy manure, and the effect of free air space on the process. Pol. J. Environ. Stud. 2014, 23, 1341-1346.

181. Gavilanes-Teran, I.; Jara-Samaniego, J.; Idrovo-Novillo, J.; Bustamante, M.A.; Moral, R.; Paredes, C. Windrow composting as horticultural waste management strategy-A case study in ecuador. Waste Manag. 2016, 48, 127-134. [CrossRef] [PubMed]

182. Mendoza-Hernandez, D.; Fornes, F.; Belda, R.M. Compost and vermicompost of horticultural waste as substrates for cutting rooting and growth of rosemary. Sci. Hortic. 2014, 178, 192-202. [CrossRef]

183. Pane, C.; Celano, G.; Piccolo, A.; Villecco, D.; Spaccini, R.; Palese, A.M.; Zaccardelli, M. Effects of on-farm composted tomato residues on soil biological activity and yields in a tomato cropping system. Chem. Biol. Technol. Agric. 2015, 2, 4. [CrossRef]

184. Tits, M.; Elsen, A.; Bries, J.; Vandendriessche, H. Short-term and long-term effects of vegetable, fruit and garden waste compost applications in an arable crop rotation in flanders. Plant Soil 2014, 376, 43-59. [CrossRef]

185. Zaller, J.G. Vermicompost in seedling potting media can affect germination, biomass allocation, yields and fruit quality of three tomato varieties. Eur. J. Soil Biol. 2007, 43, S332-S336. [CrossRef] 
186. Gutierrez-Miceli, F.A.; Santiago-Borraz, J.; Molina, J.A.M.; Nafate, C.C.; Abud-Archila, M.; Llaven, M.A.O.; Rincon-Rosales, R.; Dendooven, L. Vermicompost as a soil supplement to improve growth, yield and fruit quality of tomato (Lycopersicum esculentum). Bioresour. Technol. 2007, 98, 2781-2786. [CrossRef] [PubMed]

187. Arancon, N.Q.; Edwards, C.A.; Bierman, P.; Metzger, J.D.; Lee, S.; Welch, C. Effects of vermicomposts on growth and marketable fruits of field-grown tomatoes, peppers and strawberries. Pedobiologia 2003, 47, 731-735. [CrossRef]

188. Fernandez-Gomez, M.J.; Diaz-Ravina, M.; Romero, E.; Nogales, R. Recycling of environmentally problematic plant wastes generated from greenhouse tomato crops through vermicomposting. Int. J. Environ. Sci. Technol. 2013, 10, 697-708. [CrossRef]

189. Ertani, A.; Pizzeghello, D.; Baglieri, A.; Cadili, V.; Tambone, F.; Gennari, M.; Nardi, S. Humic-like substances from agro-industrial residues affect growth and nitrogen assimilation in maize (Zea mays L.) plantlets. J. Geochem. Explor. 2013, 129, 103-111. [CrossRef]

190. Nardi, S.; Carletti, P.; Pizzeghello, D. Biological activities of humic substances. In Biophysico-Chemical Processes Involving Natural Nonliving Organic Matter in Environmental Systems; Senesi, N., Xing, B., Huang, P., Eds.; John Wiley \& Sons: Hoboken, NJ, USA, 2009; Volume 2, pp. 305-339.

191. Lamar, R.T.; Olk, D.C.; Mayhew, L.; Bloom, P.R. A new standardized method for quantification of humic and fulvic acids in humic ores and commercial products. J. AOAC Int. 2014, 97, 721-730. [CrossRef] [PubMed]

192. Chen, Y.; Magen, H.; Riov, J. Humic substances originating from rapidly decomposing organic matter: Properties and effects on plant growth. In Humic Substances in the Global Environment and Implications on Human Health; Senesi, N., Miano, T.M., Eds.; Elsevier: New York, NY, USA, 1994; pp. 427-443.

193. Sortino, O.; Dipasquale, M.; Montoneri, E.; Tomasso, L.; Avetta, P.; Bianco Prevot, A. $90 \%$ yield increase of red pepper with unexpectedly low doses of compost soluble substances. Agron. Sustain. Dev. 2013, 33, 433-441. [CrossRef]

194. Valdrighi, M.M.; Pera, A.; Agnolucci, M.; Frassinetti, S.; Lunardi, D.; Vallini, G. Effects of compost-derived humic acids on vegetable biomass production and microbial growth within a plant (Cichorium intybus)-soil system: A comparative study. Agric. Ecosyst. Environ. 1996, 58, 133-144. [CrossRef]

195. Eyheraguibel, B.; Silvestre, J.; Morard, P. Effects of humic substances derived from organic waste enhancement on the growth and mineral nutrition of maize. Bioresour. Technol. 2008, 99, 4206-4212. [CrossRef] [PubMed]

196. Rose, M.T.; Patti, A.F.; Little, K.R.; Jackson, W.R.; Cavagnaro, T.R. A meta-analysis and review of plant-growth response to humic substances: Practical implications for agriculture. In Advances in Agronomy; Sparks, D.L., Ed.; Academic Press: Cambridge, MA, USA, 2014; Volume 124, pp. 37-89.

197. Moreno Casco, J.; Suárez Estrella, F.; López López, M.J.; Vargas García, M.C. Procedimiento de Obtención de Abono Líquido Orgánico Rico en Sustancias Húmicas a Partir de Compost de Origen Vegetal. Available online: http:/ / hdl.handle.net/10835/4367 (accessed on 15 August 2017).

198. Jurado, M.M.; Suarez-Estrella, F.; Vargas-Garcia, M.C.; Lopez, M.J.; Lopez-Gonzalez, J.A.; Moreno, J. Evolution of enzymatic activities and carbon fractions throughout composting of plant waste. J. Environ. Manag. 2014, 133, 355-364. [CrossRef] [PubMed]

199. Vargas-Garcia, M.D.; Suarez-Estrella, F.F.; Lopez, M.J.; Moreno, J. Influence of microbial inoculation and co-composting material on the evolution of humic-like substances during composting of horticultural wastes. Process Biochem. 2006, 41, 1438-1443. [CrossRef]

200. Bashan, Y.; de-Bashan, L.E.; Prabhu, S.R.; Hernandez, J.P. Advances in plant growth-promoting bacterial inoculant technology: Formulations and practical perspectives (1998-2013). Plant Soil 2014, 378, 1-33. [CrossRef]

201. Lugtenberg, B.; Kamilova, F. Plant-growth-promoting rhizobacteria. Annu. Rev. Microbiol. 2009, 63, 541-556. [CrossRef] [PubMed]

202. Borriss, R. Use of plant-associated bacillus strains as biofertilizers and biocontrol agents in agriculture. In Bacteria in Agrobiology: Plant Growth Responses; Maheshwari, D.K., Ed.; Springer: Berlin/Heidelberg, Germany, 2011; pp. 41-76.

203. Olivares, F.L.; Aguiar, N.O.; Rosa, R.C.C.; Canellas, L.P. Substrate biofortification in combination with foliar sprays of plant growth promoting bacteria and humic substances boosts production of organic tomatoes. Sci. Hortic. 2015, 183, 100-108. [CrossRef]

204. Vessey, J.K. Plant growth promoting rhizobacteria as biofertilizers. Plant Soil 2003, 255, 571-586. [CrossRef] 
205. Suarez-Estrella, F.; Jurado, M.M.; Vargas-Garcia, M.C.; Lopez, M.J.; Moreno, J. Isolation of bio-protective microbial agents from eco-composts. Biol. Control. 2013, 67, 66-74. [CrossRef]

206. Canellas, L.P.; Olivares, F.L. Physiological responses to humic substances as plant growth promoter. Chem. Biol. Technol. Agric. 2014, 1, 3. [CrossRef]

207. Martinez-Balmori, D.; Olivares, F.L.; Spaccini, R.; Aguiar, K.P.; Araujo, M.F.; Aguiar, N.O.; Guridi, F.; Canellas, L.P. Molecular characteristics of vermicompost and their relationship to preservation of inoculated nitrogen-fixing bacteria. J. Anal. Appl. Pyrol. 2013, 104, 540-550. [CrossRef]

208. Clinton, S.K. Lycopene: Chemistry, biology, and implications for human health and disease. Nutr. Rev. 1998, 56, 35-51. [CrossRef] [PubMed]

209. Sharma, S.K.; LeMaguer, M. Lycopene in tomatoes and tomato pulp fraction. Ital. J. Food Sci. 1996, 8, $107-113$.

210. Heber, D.; Lu, Q.Y. Overview of mechanisms of action of lycopene. Exp. Biol. Med. 2002, 227, $920-923$. [CrossRef]

211. Giovannucci, E. Tomato products, lycopene, and prostate cancer: A review of the epidemiological literature. J. Nutr. 2005, 135, 2030-2031.

212. Rao, A.V.; Rao, L.G. Carotenoids and human health. Pharmacol. Res. 2007, 55, 207-216. [CrossRef] [PubMed]

213. Naviglio, D.; Caruso, T.; Iannece, P.; Aragòn, A.; Santini, A. Characterization of high purity lycopene from tomato wastes using a new pressurized extraction approach. J. Agric. Food Chem. 2008, 56, 6227-6231. [CrossRef] [PubMed]

214. Strati, I.F.; Oreopoulou, V. Recovery of carotenoids from tomato processing by-products-A review. Food Res. Int. 2014, 65, 311-321. [CrossRef]

215. Cadoni, E.; De Giorgi, M.R.; Medda, E.; Poma, G. Supercritical $\mathrm{CO}_{2}$ extraction of lycopene and $\beta$-carotene from ripe tomatoes. Dyes Pigments 1999, 44, 27-32. [CrossRef]

216. Park, J.W. Coloring technology for surimi seafood. ACS Symp. Ser. 2008, 983, 254-266.

217. Metkar, S.; Saptarshi, S.; Kadam, A. Studies on extraction, isolation and applications of lycopene. IAJPR 2014, 4, 5017-5028.

218. Stajčić, S.; Ćetković, G.; Čanadanović-Brunet, J.; Djilas, S.; Mandić, A.; Četojević-Simin, D. Tomato waste: Carotenoids content, antioxidant and cell growth activities. Food Chem. 2014, 172, 225-232. [CrossRef] [PubMed]

219. Hyde, K.D.; Bahkali, A.H.; Moslem, M.A. Fungi-An unusual source for cosmetics. Fungal Divers. 2010, 43, 1-9. [CrossRef]

220. Kanno, E. Functional Cosmetic Composition. Patent JP2003212709A, 22 January 2002.

221. Ishida, B.K.; Chapman, M.H. Carotenoid extraction from plants using a novel, environmentally friendly solvent. J. Agric. Food Chem. 2009, 57, 1051-1059. [CrossRef] [PubMed]

222. Kaur, D.; Wani, A.A.; Oberoi, D.P.S.; Sogi, D.S. Effect of extraction conditions on lycopene extractions from tomato processing waste skin using response surface methodology. Food Chem. 2008, 108, 711-718. [CrossRef] [PubMed]

223. Periago, M.J.; Rincón, F.; Agüera, M.D.; Ros, G. Mixture approach for optimizing lycopene extraction from tomato and tomato products. J. Agric. Food Chem. 2004, 52, 5796-5802. [CrossRef] [PubMed]

224. Vertzoni, M.; Kartezini, T.; Reppas, C.; Archontaki, H.; Valsami, G. Solubilization and quantification of lycopene in aqueous media in the form of cyclodextrin binary systems. Int. J. Pharm. 2006, 309, 115-122. [CrossRef] [PubMed]

225. Pereira, C.S.M.; Silva, V.M.T.M.; Rodrigues, A.E. Ethyl lactate as a solvent: Properties, applications and production processes-A review. Green Chem. 2011, 13, 2658-2671. [CrossRef]

226. Clark, J.H.; Tavener, S.J. Alternative solvents: Shades of green. Org. Process Res. Dev. 2007, 11, 149-155. [CrossRef]

227. Strati, I.F.; Oreopoulou, V. Effect of extraction parameters on the carotenoid recovery from tomato waste. Int. J. Food Sci. Technol. 2011, 46, 23-29. [CrossRef]

228. Chemat-Djenni, Z.; Ferhat, M.A.; Tomao, V.; Chemat, F. Carotenoid extraction from tomato using a green solvent resulting from orange processing waste. J. Essent. Oil Bear. Plants 2010, 13, 139-147. [CrossRef]

229. Eh, A.L.-S.; Teoh, S.-G. Novel modified ultrasonication technique for the extraction of lycopene from tomatoes. Ultrason. Sonochem. 2012, 19, 151-159. [CrossRef] [PubMed]

230. Bonrath, W. Chemical reactions under "non-classical conditions", microwaves and ultrasound in the synthesis of vitamins. Ultrason. Sonochem. 2004, 11, 1-4. [CrossRef] 
231. Ho, K.K.H.Y.; Ferruzzi, M.G.; Liceaga, A.M.; San Martín-González, M.F. Microwave-assisted extraction of lycopene in tomato peels: Effect of extraction conditions on all-trans and cis-isomer yields. LWT Food Sci. Technol. 2015, 62, 160-168. [CrossRef]

232. Kusuma, H.S.; Mahfud, M. Preliminary study: Kinetics of oil extraction from sandalwood by microwave-assisted hydrodistillation. In Proceedings of the IOP Conference Series: Materials Science and Engineering, Dresden, Germany, 19-20 September 2017.

233. Lianfu, Z.; Zelong, L. Optimization and comparison of ultrasound/microwave assisted extraction (UMAE) and ultrasonic assisted extraction (UAE) of lycopene from tomatoes. Ultrason. Sonochem. 2008, 15, 731-737. [CrossRef] [PubMed]

234. Baiano, A.; Bevilacqua, L.; Terracone, C.; Contò, F.; Del Nobile, M.A. Single and interactive effects of process variables on microwave-assisted and conventional extractions of antioxidants from vegetable solid wastes. J. Food Eng. 2014, 120, 135-145. [CrossRef]

235. Choudhari, S.M.; Ananthanarayan, L. Enzyme aided extraction of lycopene from tomato tissues. Food Chem. 2007, 102, 77-81. [CrossRef]

236. Lavecchia, R.; Zuorro, A. Improved lycopene extraction from tomato peels using cell-wall degrading enzymes. Eur. Food Res. Technol. 2008, 228, 153. [CrossRef]

237. Papaioannou, E.H.; Karabelas, A.J. Lycopene recovery from tomato peel under mild conditions assisted by enzymatic pre-treatment and non-ionic surfactants. Acta Biochim. Pol. 2012, 59, 71-74. [PubMed]

238. Ranveer, R.C.; Patil, S.N.; Sahoo, A.K. Effect of different parameters on enzyme-assisted extraction of lycopene from tomato processing waste. Food Bioprod. Process. 2013, 91, 370-375. [CrossRef]

239. Cuccolini, S.; Aldini, A.; Visai, L.; Daglia, M.; Ferrari, D. Environmentally friendly lycopene purification from tomato peel waste: Enzymatic assisted aqueous extraction. J. Agric. Food Chem. 2013, 61, 1646-1651. [CrossRef] [PubMed]

240. Puri, M.; Sharma, D.; Barrow, C.J. Enzyme-assisted extraction of bioactives from plants. Trends Biotechnol. 2012, 30, 37-44. [CrossRef] [PubMed]

241. Baysal, T.; Ersus, S.; Starmans, D.A.J. Supercritical $\mathrm{CO}_{2}$ extraction of $\beta$-carotene and lycopene from tomato paste waste. J. Agi. Food Chem. 2000, 48, 5507-5511. [CrossRef]

242. Rozzi, N.L.; Singh, R.K.; Vierling, R.A.; Watkins, B.A. Supercritical fluid extraction of lycopene from tomato processing byproducts. J. Agric. Food Chem. 2002, 50, 2638-2643. [CrossRef] [PubMed]

243. Wang, L.; Weller, C.L. Recent advances in extraction of nutraceuticals from plants. Trends Food Sci. Technol. 2006, 17, 300-312. [CrossRef]

244. Kolattukudy, P. Biosynthetic Pathways of Cutin and Waxes, and their Sensitivity to Environmental Stresses. Plant Cuticles: An Integrated Functional Approach; BIOS Scientific Publishers Ltd.: Oxford, UK, 1996; pp. 83-108.

245. Kolattukudy, P.E. Cutin from plants. Biopolymers 2005. [CrossRef]

246. Benítez, J.J.; García-Segura, R.; Heredia, A. Plant biopolyester cutin: A tough way to its chemical synthesis. Biochim. Biophys. Acta 2004, 1674, 1-3. [CrossRef] [PubMed]

247. Heredia, A. Biophysical and biochemical characteristics of cutin, a plant barrier biopolymer. Biochim. Biophys. Acta 2003, 1620, 1-7. [CrossRef]

248. Li, Y.H.; Beisson, F.; Koo, A.J.K.; Molina, I.; Pollard, M.; Ohlrogge, J. Identification of acyltransferases required for cutin biosynthesis and production of cutin with suberin-like monomers. Proc. Natl. Acad. Sci. USA 2007, 104, 18339-18344. [CrossRef] [PubMed]

249. Tsatsaronis, G.C.; Boskou, D.G. Amino-acid and mineral salt content of tomato seed and skin waste. J. Sci. Food Agric. 1975, 26, 421-423. [CrossRef] [PubMed]

250. Kallio, H.; Nieminen, R.; Tuomasjukka, S.; Hakala, M. Cutin composition of five Finnish berries. J. Sci. Food Agric. 2006, 54, 457-462. [CrossRef] [PubMed]

251. Järvinen, R.; Silvestre, A.J.D.; Gil, A.M.; Kallio, H. Solid state ${ }^{13}$ C CP-MAS NMR and FT-IR spectroscopic analysis of cuticular fractions of berries and suberized membranes of potato. J. Food Compos. Anal. 2011, 24, 334-345. [CrossRef]

252. Koskimies, S.; Hulkko, J.; Pitkänen, P.; Heiskanen, N.; Yli-Kauhaluoma, J.; Wähälä, K. Method for the Manufacture of Oligo- and Polyesters from a Mixture of Carboxylic Acid Obtained from Suberin and/or Cutin and Use Thereof. U.S. Patent US20110319504 A1, 8 September 2011.

253. Osman, S.F.; Irwin, P.; Fett, W.F.; O'Conno, J.V.; Parris, N. Preparation, isolation, and characterization of cutin monomers and oligomers from tomato peels. J. Sci. Food Agric. 1999, 47, 799-802. [CrossRef] 
254. Luque, P.; Bruque, S.; Heredia, A. Water permeability of isolated cuticular membranes: A structural analysis. Arch. Biochem. Biophys. 1995, 317, 417-422. [CrossRef] [PubMed]

255. Chefetz, B. Decomposition and sorption characterization of plant cuticles in soil. Plant Soil 2007, 298, 21-30. [CrossRef]

256. Shechter, M.; Xing, B.; Kopinke, F.-D.; Chefetz, B. Competitive sorption-desorption behavior of triazine herbicides with plant cuticular fractions. J. Sci. Food Agric. 2006, 54, 7761-7768. [CrossRef] [PubMed]

257. Hauff, S.; Chefetz, B.; Shechter, M.; Vetter, W. Determination of hydroxylated fatty acids from the biopolymer of tomato cutin and their fate during incubation in soil. Phytochem Anal. 2010, 21, 582-589. [CrossRef] [PubMed]

258. Cigognini, I.; Montanari, A.; De la Torre Carreras, R.; Cardoso, G. Extraction Method of a Polyester Polymer or Cutin from the Wasted Tomato Peels and Polyester Polimer so Extracted. Patent WO2015028299 (A1), 5 March 2015.

259. Montanari, A.; Bolzoni, L.; Cigognini, I.M.; Carreras, R.D. Tomato bio-based lacquer for sustainable metal packaging. Agro Food Ind. Hi Tec 2014, 25, 50-54. [CrossRef]

260. Encinar, J.M.; González, J.F.; Martínez, G. Energetic use of the tomato plant waste. Fuel Process. Technol. 2008, 89, 1193-1200. [CrossRef]

261. Zhang, R.Y. What to Do with Tomato Plant Wastes after Ketchup? Available online: http:/ / www.biofuelnet. ca/author/ryan-yongsheng-zhang/ (accessed on 3 May 2015).

262. Tabasso, S.; Montoneri, E.; Carnaroglio, D.; Caporaso, M.; Cravotto, G. Microwave-assisted flash conversion of non-edible polysaccharides and post-harvest tomato plant waste to levulinic acid. Green Chem. 2014, 16, 73-76. [CrossRef]

263. Buttery, R.G.; Ling, L.C.; Light, D.M. Tomato leaf volatile aroma components. J. Agric. Food Chem. 1987, 35, 1039-1042. [CrossRef]

264. Baldwin, E.A.; Scott, J.W.; Shewmaker, C.K.; Schuch, W. Flavor trivia and tomato aroma: Biochemistry and possible mechanisms for control of important aroma components. Hortscience 2000, 35, 1013-1022.

265. Tabart, J.; Kevers, C.; Sipel, A.; Pincemail, J.; Defraigne, J.O.; Dommes, J. Optimisation of extraction of phenolics and antioxidants from black currant leaves and buds and of stability during storage. Food Chem. 2007, 105, 1268-1275. [CrossRef]

266. Sun, T.; Ho, C.T. Antioxidant activities of buckwheat extracts. Food Chem. 2005, 90, 743-749. [CrossRef]

267. Savatović, S.M.; Ćetković, G.S.; Čanadanović-Brunet, J.M.; Đilas, S.M. Utilization of tomato waste as a source of polyphenolic antioxidants. Acta Period. Technol. 2010, 41, 187-194. [CrossRef]

268. Chandi, G.K.; Singh, S.P.; Gill, B.S.; Sogi, D.S.; Singh, P. Optimization of carotenoids by rhodotorula glutinis. Food Sci. Biotechnol. 2010, 19, 881-887. [CrossRef]

269. Moayedi, A.; Hashemi, M.; Safari, M. Valorization of tomato waste proteins through production of antioxidant and antibacterial hydrolysates by proteolytic bacillus subtilis: Optimization of fermentation conditions. J. Food Sci. Technol. 2016, 53, 391-400. [CrossRef] [PubMed]

270. Di Gioia, D.; Fava, F.; Luziatelli, F.; Ruzzi, M. Vanillin production from agro-industrial wastes. In Comprehensive Biotechnology, 2nd ed.; Murray, M.-Y., Ed.; Academic Press: Burlington, VT, USA, 2011.

271. FAO. Fao Cereal Supply and Demand Brief. Available online: www.fao.org/worldfoodsituation/csdb/en (accessed on 11 November 2016).

272. FAOSTAT Crops. Available online: http:/ /faostat3.fao.org/browse/Q/QC/E (accessed on 11 November 2016).

273. Reisinger, M.; Tirpanalan, O.; Pruckler, M.; Huber, F.; Kneifel, W.; Novalin, S. Wheat bran biorefinery-A detailed investigation on hydrothermal and enzymatic treatment. Bioresour. Technol. 2013, 144, 179-185. [CrossRef] [PubMed]

274. Pruckler, M.; Siebenhandl-Ehn, S.; Apprich, S.; Holtinger, S.; Haas, C.; Schmid, E.; Kneifel, W. Wheat bran-based biorefinery 1: Composition of wheat bran and strategies of functionalization. LWT Food Sci. Technol. 2014, 56, 211-221. [CrossRef]

275. Soukoulis, C.; Aprea, E. Cereal bran fractionation: Processing techniques for the recovery of functional components and their applications to the food industry. Recent Patent. Food Nutr. Agric. 2012, 4, 61-77.

276. Akil, H.M.; Omar, M.F.; Mazuki, A.A.M.; Safiee, S.; Ishak, Z.A.M.; Abu Bakar, A. Kenaf fiber reinforced composites: A review. Mater. Des. 2011, 32, 4107-4121. [CrossRef]

277. Kozlowski, R.; Mieleniak, B.; Helwig, M.; Przepiera, A. Flame resistant lignocellulosic-mineral composite particleboards. Polym. Degrad Stabil. 1999, 64, 523-528. [CrossRef] 
278. Kim, J.; Yun, S.; Ounaies, Z. Discovery of cellulose as a smart material. Macromolecules 2006, 39, 4202-4206. [CrossRef]

279. Hunter, I.R. Bamboo resources, uses and trade: The future? J. Bamboo Rattan 2003, 2, 319-326. [CrossRef]

280. Parameswaran, N.; Liese, W. On the fine structure of bamboo fibres. Wood Sci. Technol. 1976, 10, $231-246$.

281. Mohanty, A.K.; Misra, M.; Hinrichsen, G. Biofibres, biodegradable polymers and biocomposites: An overview. Macromol. Mater. Eng. 2000, 276, 1-24. [CrossRef]

282. Henriksson, M.; Henriksson, G.; Berglund, L.A.; Lindstrom, T. An environmentally friendly method for enzyme-assisted preparation of microfibrillated cellulose (MFC) nanofibers. Eur. Polym. J. 2007, 43, 3434-3441. [CrossRef]

283. Isogai, A.; Saito, T.; Fukuzumi, H. Tempo-oxidized cellulose nanofibers. Nanoscale 2011, 3, 71-85. [CrossRef] [PubMed]

284. Paakko, M.; Ankerfors, M.; Kosonen, H.; Nykanen, A.; Ahola, S.; Osterberg, M.; Ruokolainen, J.; Laine, J.; Larsson, P.T.; Ikkala, O.; et al. Enzymatic hydrolysis combined with mechanical shearing and high-pressure homogenization for nanoscale cellulose fibrils and strong gels. Biomacromolecules 2007, 8, 1934-1941. [CrossRef] [PubMed]

285. Moon, R.J.; Martini, A.; Nairn, J.; Simonsen, J.; Youngblood, J. Cellulose nanomaterials review: Structure, properties and nanocomposites. Chem. Soc. Rev. 2011, 40, 3941-3994. [CrossRef] [PubMed]

286. Jonoobi, M.; Oladi, R.; Davoudpour, Y.; Oksman, K.; Dufresne, A.; Hamzeh, Y.; Davoodi, R. Different preparation methods and properties of nanostructured cellulose from various natural resources and residues: A review. Cellulose 2015, 22, 935-969. [CrossRef]

287. Alemdar, A.; Sain, M. Isolation and characterization of nanofibers from agricultural residues - wheat straw and soy hulls. Bioresour. Technol. 2008, 99, 1664-1671. [CrossRef] [PubMed]

288. Kaushik, A.; Singh, M. Isolation and characterization of cellulose nanofibrils from wheat straw using steam explosion coupled with high shear homogenization. Carbohydr. Res. 2011, 346, 76-85. [CrossRef] [PubMed]

289. Jonoobi, M.; Khazaeian, A.; Tahir, P.M.; Azry, S.S.; Oksman, K. Characteristics of cellulose nanofibers isolated from rubberwood and empty fruit bunches of oil palm using chemo-mechanical process. Cellulose 2011, 18, 1085-1095. [CrossRef]

290. Dufresne, A.; Cavaille, J.Y.; Vignon, M.R. Mechanical behavior of sheets prepared from sugar beet cellulose microfibrils. J. Appl. Polym. Sci. 1997, 64, 1185-1194. [CrossRef]

291. Dufresne, A.; Vignon, M.R. Improvement of starch film performances using cellulose microfibrils. Macromolecules 1998, 31, 2693-2696. [CrossRef]

292. Bruce, D.M.; Hobson, R.N.; Farrent, J.W.; Hepworth, D.G. High-performance composites from low-cost plant primary cell walls. Compos. Appl. Sci. Manuf. 2005, 36, 1486-1493. [CrossRef]

293. Bhattacharya, D.; Germinario, L.T.; Winter, W.T. Isolation, preparation and characterization of cellulose microfibers obtained from bagasse. Carbohydr. Polym. 2008, 73, 371-377. [CrossRef]

294. Hassan, M.L.; Mathew, A.P.; Hassan, E.A.; El-Wakil, N.A.; Oksman, K. Nanofibers from bagasse and rice straw: Process optimization and properties. Wood Sci. Technol. 2012, 46, 193-205. [CrossRef]

295. Zuluaga, R.; Putaux, J.L.; Cruz, J.; Velez, J.; Mondragon, I.; Ganan, P. Cellulose microfibrils from banana rachis: Effect of alkaline treatments on structural and morphological features. Carbohydr. Polym. 2009, 76, 51-59. [CrossRef]

296. Tibolla, H.; Pelissari, F.M.; Menegalli, F.C. Cellulose nanofibers produced from banana peel by chemical and enzymatic treatment. LWT Food Sci. Technol. 2014, 59, 1311-1318. [CrossRef]

297. Spence, K.L.; Venditti, R.A.; Rojas, O.J.; Habibi, Y.; Pawlak, J.J. A comparative study of energy consumption and physical properties of microfibrillated cellulose produced by different processing methods. Cellulose 2011, 18, 1097-1111. [CrossRef]

298. Purkait, B.S.; Ray, D.; Sengupta, S.; Kar, T.; Mohanty, A.; Misra, M. Isolation of cellulose nanoparticles from sesame husk. Ind. Eng. Chem. Res. 2011, 50, 871-876. [CrossRef]

299. Apprich, S.; Tirpanalan, O.; Hell, J.; Reisinger, M.; Bohmdorfer, S.; Siebenhandl-Ehn, S.; Novalin, S.; Kneifel, W. Wheat bran-based biorefinery 2: Valorization of products. LWT Food Sci. Technol. 2014, 56, 222-231. [CrossRef]

300. Luthria, D.L.; Lu, Y.J.; John, K.M.M. Bioactive phytochemicals in wheat: Extraction, analysis, processing, and functional properties. J. Funct. Foods 2015, 18, 910-925. [CrossRef]

301. Kroon, P.A.; Faulds, C.B.; Ryden, P.; Robertson, J.A.; Williamson, G. Release of covalently bound ferulic acid from fiber in the human colon. J. Agric. Food Chem. 1997, 45, 661-667. [CrossRef] 
302. Liyana-Pathirana, C.M.; Shahidi, F. Importance of insoluble-bound phenolics to antioxidant properties of wheat. J. Agric. Food Chem. 2006, 54, 1256-1264. [CrossRef] [PubMed]

303. Ou, S.; Kwok, K.-C. Ferulic acid: Pharmaceutical functions, preparation and applications in foods. J. Sci. Food Agric. 2004, 84, 1261-1269. [CrossRef]

304. Fava, F.; Zanaroli, G.; Vannini, L.; Guerzoni, E.; Bordoni, A.; Viaggi, D.; Robertson, J.; Waldron, K.; Bald, C.; Esturo, A.; et al. New advances in the integrated management of food processing by-products in Europe: Sustainable exploitation of fruit and cereal processing by-products with the production of new food products (NAMASTE EU). New Biotechnol. 2013, 30, 647-655. [CrossRef] [PubMed]

305. Tirpanalan, O.; Reisinger, M.; Huber, F.; Kneifel, W.; Novalin, S. Wheat bran biorefinery: An investigation on the starch derived glucose extraction accompanied by pre- and post-treatment steps. Bioresour. Technol. 2014, 163, 295-299. [CrossRef] [PubMed]

306. Wood, I.P.; Cook, N.M.; Wilson, D.R.; Ryden, P.; Robertson, J.A.; Waldron, K.W. Ethanol from a biorefinery waste stream: Saccharification of amylase, protease and xylanase treated wheat bran. Food Chem. 2016, 198, 125-131. [CrossRef] [PubMed]

307. Brewer, L.R.; Kubola, J.; Siriamornpun, S.; Herald, T.J.; Shi, Y.C. Wheat bran particle size influence on phytochemical extractability and antioxidant properties. Food Chem. 2014, 152, 483-490. [CrossRef] [PubMed]

308. Hell, J.; Donaldson, L.; Michlmayr, H.; Kraler, M.; Kneifel, W.; Potthast, A.; Rosenau, T.; Bohmdorfer, S. Effect of pretreatment on arabinoxylan distribution in wheat bran. Carbohydr. Polym. 2015, 121, 18-26. [CrossRef] [PubMed]

309. Liu, L.Y.; Zhao, M.L.; Liu, X.X.; Zhong, K.; Tong, L.T.; Zhou, X.R.; Zhou, S.M. Effect of steam explosion-assisted extraction on phenolic acid profiles and antioxidant properties of wheat bran. J. Sci. Food Agric. 2016, 96, 3484-3491. [CrossRef] [PubMed]

310. Merali, Z.; Collins, S.R.A.; Elliston, A.; Wilson, D.R.; Kasper, A.; Waldron, K.W. Characterization of cell wall components of wheat bran following hydrothermal pretreatment and fractionation. Biotechnol. Biofuels 2015. [CrossRef] [PubMed]

311. Reisinger, M.; Tirpanalan, O.; Huber, F.; Kneifel, W.; Novalin, S. Investigations on a wheat bran biorefinery involving organosolv fractionation and enzymatic treatment. Bioresour. Technol. 2014, 170, 53-61. [CrossRef] [PubMed]

312. Hromadkova, Z.; Kost'alova, Z.; Ebringerova, A. Comparison of conventional and ultrasound-assisted extraction of phenolics-rich heteroxylans from wheat bran. Ultrason. Sonochem. 2008, 15, 1062-1068. [CrossRef] [PubMed]

313. Lu, Y.J.; Luthria, D. Influence of gelatinization on the extraction of phenolic acids from wheat fractions. Food Chem. 2016, 194, 1138-1142. [CrossRef] [PubMed]

314. Lasrado, L.D.; Gudipati, M. Antioxidant property of synbiotic combination of lactobacillus sp and wheat bran xylo-oligosaccharides. J. Food Sci. Technol. 2015, 52, 4551-4557. [CrossRef] [PubMed]

315. Hromadkova, Z.; Paulsen, B.S.; Polovka, M.; Kost'alova, Z.; Ebringerova, A. Structural features of two heteroxylan polysaccharide fractions from wheat bran with anti-complementary and antioxidant activities. Carbohydr. Polym. 2013, 93, 22-30. [CrossRef] [PubMed]

316. Llevot, A.; Grau, E.; Carlotti, S.; Grelier, S.; Cramail, H. From lignin-derived aromatic compounds to novel biobased polymers. Macromol. Rapid Comm. 2016, 37, 9-28. [CrossRef] [PubMed]

317. Bock, L.H.; Anderson, J.K. Linear polyesters derived from vanillic acid. J. Polym. Sci. 1955, 17, 553-558. [CrossRef]

318. Era, V.; Hannula, J. Polyesters from vanillin-synthesis and characterization. Paperi ja Puu 1974, 56, 489.

319. Ishikawa, K. Nippon Kagaku Zasshi. Journal of the Chemical Society of Japan: Pure Chemistry Section. Available online: http:/ / www.worldcat.org/title/journal-of-the-chemical-society-of-japan-pure-chemistrysection-nippon-kagaku-zasshi/oclc/476489674 (accessed on 15 August 2017).

320. Lange, W.; Kordsachia, O. Preparation and properties of polyesters from vanillin and syringaaldehyde a contribution to possible utilization of hardwood lignins. Holz als Roh-und Werkstoff 1981, 39, 107-112. [CrossRef]

321. Mialon, L.; Pemba, A.G.; Miller, S.A. Biorenewable polyethylene terephthalate mimics derived from lignin and acetic acid. Green Chem. 2010, 12, 1704-1706. [CrossRef]

322. Mialon, L.; Vanderhenst, R.; Pemba, A.G.; Miller, S.A. Polyalkylenehydroxybenzoates (PAHBs): Biorenewable aromatic/aliphatic polyesters from lignin. Macromol. Rapid Commun. 2011, 32, 1386-1392. [CrossRef] [PubMed] 
323. Gioia, C.; Banella, M.B.; Marchese, P.; Vannini, M.; Colonna, M.; Celli, A. Advances in the synthesis of bio-based aromatic polyesters: Novel copolymers derived from vanillic acid and epsilon-caprolactone. Polym. Chem. UK 2016, 7, 5396-5406. [CrossRef]

324. Kreye, O.; Oelmann, S.; Meier, M.A. Renewable aromatic-aliphatic copolyesters derived from rapeseed. Macromolecul. Chem. Phys. 2013, 214, 1452-1464. [CrossRef]

325. Firdaus, M.; Meier, M.A.R. Renewable co-polymers derived from vanillin and fatty acid derivatives. Eur. Polym. J. 2013, 49, 156-166. [CrossRef]

326. Pang, C.C.; Zhang, J.; Wu, G.L.; Wang, Y.N.; Gao, H.; Ma, J.B. Renewable polyesters derived from 10-undecenoic acid and vanillic acid with versatile properties. Polym. Chem. UK 2014, 5, 2843-2853. [CrossRef]

327. Pion, F.; Reano, A.F.; Ducrot, P.H.; Allais, F. Chemo-enzymatic preparation of new bio-based bis-and trisphenols: New versatile building blocks for polymer chemistry. RSC Adv. 2013, 3, 8988-8997. [CrossRef]

328. Llevot, A.; Grau, E.; Carlotti, S.; Grelier, S.; Cramail, H. Renewable (SEMI) aromatic polyesters from symmetrical vanillin-based dimers. Polym. Chem. UK 2015, 6, 6058-6066. [CrossRef]

329. Goto, T.; Ishii, D.; Enomoto-Rogers, Y.; Takemura, A.; Iwata, T. Synthesis and characterization of poly [(ferulic acid)-alt-(glycine)]. Polymer 2017, 112, 385-392. [CrossRef]

330. Graf, E. Antioxidant potential of ferulic acid. Free Radic. Biol. Med. 1992, 13, 435-448. [CrossRef]

331. Mori, H.; Kawabata, K.; Yoshimi, N.; Tanaka, T.; Murakami, T.; Okada, T.; Murai, H. Chemopreventive effects of ferulic acid on oral and rice germ on large bowel carcinogenesis. Anticancer Res. 1999, 19, 3775-3778. [PubMed]

332. Ooishi, N.; Shibata, T.; Ikeda, K. Stabilized oral preparations containing ulcer inhibitors. Jpn. Kokai Tokkyo Koho JP 1993, 5, 194-225.

333. Ouimet, M.A.; Griffin, J.; Carbone-Howell, A.L.; Wu, W.H.; Stebbins, N.D.; Di, R.; Uhrich, K.E. Biodegradable ferulic acid-containing poly(anhydride-ester): Degradation products with controlled release and sustained antioxidant activity. Biomacromolecules 2013, 14, 854-861. [CrossRef] [PubMed]

334. Ouimet, M.A.; Faig, J.J.; Yu, W.; Uhrich, K.E. Ferulic acid-based polymers with glycol functionality as a versatile platform for topical applications. Biomacromolecules 2015, 16, 2911-2919. [CrossRef] [PubMed]

335. Coelho, C.; Hennous, M.; Verney, V.; Leroux, F. Functionalisation of polybutylene succinate nanocomposites: From structure to reinforcement of uv-absorbing and mechanical properties. RSC Adv. 2012, 2, 5430-5438. [CrossRef]

336. Reano, A.F.; Cherubin, J.; Peru, A.M.M.; Wang, Q.; Clement, T.; Domenek, S.; Allais, F. Structure-activity relationships and structural design optimization of a series of p-hydroxycinnamic acids-based bis- and trisphenols as novel sustainable antiradical/antioxidant additives. ACS. Sustain. Chem. Eng. 2015, 3, 3486-3496. [CrossRef]

337. Reano, A.F.; Domenek, S.; Pernes, M.; Beaugrand, J.; Allais, F. Ferulic acid-based bis/trisphenols as renewable antioxidants for polypropylene and poly (butylene succinate). ACS. Sustain. Chem. Eng. 2016, 4, 6562-6571. [CrossRef]

338. Cerruti, P.; Malinconico, M.; Rychly, J.; Matisova-Rychla, L.; Carfagna, C. Effect of natural antioxidants on the stability of polypropylene films. Polym. Degrad Stabil. 2009, 94, 2095-2100. [CrossRef]

339. Parisi, O.I.; Puoci, F.; Iemma, F.; De Luca, G.; Curcio, M.; Cirillo, G.; Spizzirri, U.G.; Picci, N. Antioxidant and spectroscopic studies of crosslinked polymers synthesized by grafting polymerization of ferulic acid. Polym. Advan. Technol. 2010, 21, 774-779. [CrossRef]

340. Iemma, F.; Puoci, F.; Curcio, M.; Parisi, O.I.; Cirillo, G.; Spizzirri, U.G.; Picci, N. Ferulic acid as a comonomer in the synthesis of a novel polymeric chain with biological properties. J. Appl. Polym. Sci. 2010, 115, 784-789. [CrossRef]

341. Du, J.; Fang, Y.Y.; Zheng, Y.B. Synthesis and characterization of poly (L-lactic acid) reinforced by biomesogenic units. Polym. Degrad Stabil. 2008, 93, 838-845. [CrossRef]

342. Cerruti, P.; Santagata, G.; d'Ayala, G.G.; Ambrogi, V.; Carfagna, C.; Malinconico, M.; Persico, P. Effect of a natural polyphenolic extract on the properties of a biodegradable starch-based polymer. Polym. Degrad Stabil. 2011, 96, 839-846. [CrossRef]

343. Kim, D.J.; Kim, W.S.; Lee, D.H.; Min, K.E.; Park, L.S.; Kang, I.K.; Jeon, I.R.; Seo, K.H. Modification of poly(Butylene succinate) with peroxide: Crosslinking, physical and thermal properties, and biodegradation. J. Appl. Polym. Sci. 2001, 81, 1115-1124. [CrossRef] 
344. Rizzarelli, P.; Carroccio, S. Thermo-oxidative processes in biodegradable poly (Butylene succinate). Polym. Degrad Stabil. 2009, 94, 1825-1838. [CrossRef]

345. Poopathi, S.; Archana, B. Production of bacillus thuringiensis subsp israelensis from agro-based product (corncob). Curr. Sci. 2011, 101, 1009-1010.

346. Velasquez, A.; Arias, R. Effect of substrate on the in vitro protein digestibility of extracts generated by saccharomyces cerevisiae. Ciencia E Investigación Agraria 2013, 40, 503-511. [CrossRef]

347. Yunus, F.U.N.; Nadeem, M.; Rashid, F. Single-cell protein production through microbial conversion of lignocellulosic residue (wheat bran) for animal feed. J. I. Brewing 2015, 121, 553-557. [CrossRef]

348. Tejeda-Ricardez, J.; Vaca-Garcia, C.; Borredon, M.E. Design of a batch solvolytic liquefaction reactor for the valorization of residues from the agricultural foodstuff. Chem. Eng. Res. Des. 2003, 81, 1066-1070. [CrossRef]

349. Demirbas, A.; Caglar, A.; Akdeniz, F.; Gullu, D. Conversion of olive husk to liquid fuel by pyrolysis and catalytic liquefaction. Energy Sources 2000, 22, 631-639.

350. Çağlar, A.; Demirbaş, A. Hydrogen rich gas mixture from olive husk via pyrolysis. Energy Convers. Manag. 2002, 43, 109-117. [CrossRef]

351. Rao, T.R.; Sharma, A. Pyrolysis rates of biomass materials. Energy 1998, 23, 973-978. [CrossRef]

352. Georgieva, T.I.; Ahring, B.K. Potential of agroindustrial waste from olive oil industry for fuel ethanol production. Biotechnol. J. 2007, 2, 1547-1555. [CrossRef] [PubMed]

353. Fernandez-Bolanos, J.; Rodriguez, G.; Rodriguez, R.; Guillen, R.; Jimenez, A. Extraction of interesting organic compounds from olive oil waste. Grasas Aceites 2006, 57, 95-106. [CrossRef]

354. Reboredo-Rodríguez, P.; González-Barreiro, C.; Cancho-Grande, B.; Simal-Gándara, J. Dynamic headspace/gc-ms to control the aroma fingerprint of extra-virgin olive oil from the same and different olive varieties. Food Control. 2012, 25, 684-695. [CrossRef]

355. Reboredo-Rodriguez, P.; Gonzalez-Barreiro, C.; Cancho-Grande, B.; Simal-Gandara, J. Aroma biogenesis and distribution between olive pulps and seeds with identification of aroma trends among cultivars. Food Chem. 2013, 141, 637-643. [CrossRef] [PubMed]

356. Mason, W. Apparatus for and Explosion Fibration of Lignocellulose Material. U.S. Patent 1655618A, 10 January 1928.

357. Biswas, A.K.; Umeki, K.; Yang, W.; Blasiak, W. Change of pyrolysis characteristics and structure of woody biomass due to steam explosion pretreatment. Fuel Process. Technol. 2011, 92, 1849-1854. [CrossRef]

358. Kataria, R.; Mol, A.; Schulten, E.; Happel, A.; Mussatto, S.I. Bench scale steam explosion pretreatment of acid impregnated elephant grass biomass and its impacts on biomass composition, structure and hydrolysis. Ind. Crop. Prod. 2016, 106, 48-58. [CrossRef]

359. Duque, A.; Manzanares, P.; Ballesteros, I.; Ballesteros, M. Biomass Fractionation Technologies for a Lignocellulosic Feedstock Based Biorefinery, 1st ed.; Elsevier: Amsterdam, The Netherlands, 2016; pp. 349-368.

360. Cara, C.; Ruiz, E.; Ballesteros, I.; Negro, M.J.; Castro, E. Enhanced enzymatic hydrolysis of olive tree wood by steam explosion and alkaline peroxide delignification. Process Biochem. 2006, 41, 423-429. [CrossRef]

361. Ballesteros, I.; Oliva, J.M.; Saez, F.; Ballesteros, M. Ethanol production from lignocellulosic byproducts of olive oil extraction. Appl. Biochem. Biotechnol. 2001, 91, 237-252. [CrossRef]

362. Spinelli, R.; Picchi, G. Industrial harvesting of olive tree pruning residue for energy biomass. Bioresour. Technol. 2010, 101, 730-735. [CrossRef] [PubMed]

363. Ballesteros, I.; Ballesteros, M.; Cara, C.; Sáez, F.; Castro, E.; Manzanares, P.; Negro, M.J.; Oliva, J.M. Effect of water extraction on sugars recovery from steam exploded olive tree pruning. Bioresour. Technol. 2011, 102, 6611-6616. [CrossRef] [PubMed]

364. Conde, E.; Cara, C.; Moure, A.; Ruiz, E.; Castro, E.; Domínguez, H. Antioxidant activity of the phenolic compounds released by hydrothermal treatments of olive tree pruning. Food Chem. 2009, 114, 806-812. [CrossRef]

365. Dermeche, S.; Nadour, M.; Larroche, C.; Moulti-Mati, F.; Michaud, P. Olive mill wastes: Biochemical characterizations and valorization strategies. Process Biochem. 2013, 48, 1532-1552. [CrossRef]

366. Fernandez-Bolanos, J.; Felizon, B.; Heredia, A.; Guillen, R.; Jimenez, A. Characterization of the lignin obtained by alkaline delignification and of the cellulose residue from steam-exploded olive stones. Bioresour. Technol. 1999, 68, 121-132. [CrossRef]

367. Felizón, B.; Fernández-Bolaños, J.; Heredia, A.; Guillén, R. Steam-explosion pretreatment of olive cake. J. Am. Oil Chem. Soc. 2000, 77, 15-22. [CrossRef] 
368. Fernández-Bolaños, J.; Felizón, B.; Brenes, M.; Guillén, R.; Heredia, A. Hydroxytyrosol and tyrosol as the main compounds found in the phenolic fraction of steam-exploded olive stones. J. Am. Oil Chem. Soc. 1998, 75, 1643-1649. [CrossRef]

369. Berthet, M.A.; Angellier-Coussy, H.; Machado, D.; Hilliou, L.; Staebler, A.; Vicente, A.; Gontard, N. Exploring the potentialities of using lignocellulosic fibres derived from three food by-products as constituents of biocomposites for food packaging. Ind. Crop. Prod. 2015, 69, 110-122. [CrossRef]

370. Bouknana, D.; Hammouti, B.; Salghi, R.; Jodeh, S.; Zarrouk, A.; Warad, I.; Aouniti, A.; Sbaa, M. Physicochemical characterization of olive oil mill wastewaters in the eastern region of morocco. J. Mater. Environ. Sci. 2014, 5, 1039-1058.

371. Meftah, H.; Latrache, H.; Hamadi, F.; Hanine, H.; Zahir, H.; El louali, M. Comparaison des caractéristiques physicochimiques des huiles d'olives issus de différentes zones de la région tadla azilal (maroc)[comparison of the physico-chemical characteristics of the olive oil coming from different zones in tadla azilal area (morocco)]. J. Mater. Environ. Sci. 2014, 5, 641-646.

372. Taamalli, A.; Arráez-Román, D.; Barrajón-Catalán, E.; Ruiz-Torres, V.; Pérez-Sánchez, A.; Herrero, M.; Ibañez, E.; Micol, V.; Zarrouk, M.; Segura-Carretero, A.; et al. Use of advanced techniques for the extraction of phenolic compounds from Tunisian olive leaves: Phenolic composition and cytotoxicity against human breast cancer cells. Food Chem. Toxicol. 2012, 50, 1817-1825. [CrossRef] [PubMed]

373. Zahari, A.; Tazi, A.; Azzi, M. Optimisation des conditions de traitement des margines par un superoxydant k3fexmnyo8 [optimization of treatment conditions of olive oil mill wastewater by superoxidant k3fexmnyo8]. J. Mater. Environ. Sci. 2014, 5, 2484-2489.

374. Bucić-Kojić, A.; Planinić, M.; Tomas, S.; Jakobek, L.; Šeruga, M. Influence of solvent and temperature on extraction of phenolic compounds from grape seed, antioxidant activity and colour of extract. Int. J. Food Sci. Technol. 2009, 44, 2394-2401. [CrossRef]

375. Spigno, G.; Tramelli, L.; De Faveri, D.M. Effects of extraction time, temperature and solvent on concentration and antioxidant activity of grape marc phenolics. J. Food Eng. 2007, 81, 200-208. [CrossRef]

376. Paini, M.; Casazza, A.A.; Aliakbarian, B.; Perego, P.; Binello, A.; Cravotto, G. Influence of ethanol/water ratio in ultrasound and high-pressure/high-temperature phenolic compound extraction from agri-food waste. Int. J. Food Sci. Technol. 2016, 51, 349-358. [CrossRef]

377. Winkelhausen, E.; Pospiech, R.; Laufenberg, G. Antifungal activity of phenolic compounds extracted from dried olive pomace. Bull. Chem. Technol. Macedonia 2005, 24, 41-46.

378. Vergani, L.; Vecchione, G.; Baldini, F.; Voci, A.; Ferrari, P.F.; Aliakbarian, B.; Casazza, A.A.; Perego, P. Antioxidant and hepatoprotective potentials of phenolic compounds from olive pomace. Chem. Eng. Trans. 2016, 49, 475-480.

379. Cardoso, S.M.; Guyot, S.; Marnet, N.; Lopes-da-Silva, J.A.; Renard, C.M.G.C.; Coimbra, M.A. Characterisation of phenolic extracts from olive pulp and olive pomace by electrospray mass spectrometry. J. Sci. Food Agric. 2005, 85, 21-32. [CrossRef]

380. Li, C.; Zheng, Y.Y.; Wang, X.F.; Feng, S.L.; Di, D.L. Simultaneous separation and purification of flavonoids and oleuropein from Olea europaea L. (olive) leaves using macroporous resin. J. Sci. Food Agric. 2011, 91, 2826-2834. [CrossRef] [PubMed]

381. Japón-Luján, R.; de Castro, M.D.L. Superheated liquid extraction of oleuropein and related biophenols from olive leaves. J. Chromatogr. A 2006, 1136, 185-191. [CrossRef] [PubMed]

382. Khemakhem, I.; Ahmad-Qasem, M.H.; Catalán, E.B.; Micol, V.; García-Pérez, J.V.; Ayadi, M.A.; Bouaziz, M. Kinetic improvement of olive leaves' bioactive compounds extraction by using power ultrasound in a wide temperature range. Ultrason. Sonochem. 2017, 34, 466-473. [CrossRef] [PubMed]

383. Ansari, M.; Kazemipour, M.; Fathi, S. Development of a simple green extraction procedure and hplc method for determination of oleuropein in olive leaf extract applied to a multi-source comparative study. J. Iran. Chem. Soc. 2011, 8, 38-47. [CrossRef]

384. Heemken, O.P.; Theobald, N.; Wenclawiak, B.W. Comparison of ASE and SFE with soxhlet, sonication, and methanolic saponification extractions for the determination of organic micropollutants in marine particulate matter. Anal. Chem. 1997, 69, 2171-2180. [CrossRef] [PubMed]

385. Procopio, A.; Alcaro, S.; Nardi, M.; Oliverio, M.; Ortuso, F.; Sacchetta, P.; Pieragostino, D.; Sindona, G. Synthesis, biological evaluation, and molecular modeling of oleuropein and its semisynthetic derivatives as cyclooxygenase inhibitors. J. Agric. Food Chem. 2009, 57, 11161-11167. [CrossRef] [PubMed] 
386. Sifaoui, I.; Chammem, N.; Abderrabba, M.; Mejri, M. Optimization of phenolic compounds extraction from olive leaves using experimental design methodology. J. Mater. Environ. Sci. 2016, 7, 1119-1127.

387. Mkaouar, S.; Bahloul, N.; Gelicus, A.; Allaf, K.; Kechaou, N. Instant controlled pressure drop texturing for intensifying ethanol solvent extraction of olive (Olea europaea) leaf polyphenols. Separ. Purif. Tech. 2015, 145, 139-146. [CrossRef]

388. Tsakona, S.; Galanakis, C.M.; Gekas, V. Hydro-ethanolic mixtures for the recovery of phenols from mediterranean plant materials. Food Bioprocess Technol. 2012, 5, 1384-1393. [CrossRef]

389. Hayes, J.E.; Allen, P.; Brunton, N.; O'Grady, M.N.; Kerry, J.P. Phenolic composition and in vitro antioxidant capacity of four commercial phytochemical products: Olive leaf extract (Olea europaea L.), lutein, sesamol and ellagic acid. Food Chem. 2011, 126, 948-955. [CrossRef]

390. Niaounakis, M.; Halvadakis, C.P. Olive Processing Waste Management: Literature Review and Patent Survey, 2nd ed.; Elsevier: Amsterdam, The Netherlands, 2006; Volume 5.

391. Rafiee, Z.; Jafari, S.M.; Alami, M.; Khomeiri, M. Antioxidant effect of microwave-assisted extracts of olive leaves on sunflower oil. J. Agric. Sci. Technol. 2012, 14, 1497-1509.

392. Components as related to human health: Recent developments. Austin. J. Nutr. Food Sci. 2015, 3, 3.

393. Skaltsounis, A.L.; Argyropoulou, A.; Aligiannis, N.; Xynos, N. Recovery of high added value compounds from olive tree products and olive processing byproducts. In Olive and Olive Oil Bioactive Constituents, 1st ed.; Dimitrios, B., Ed.; Elsevier: Amsterdam, The Netherlands, 2015; pp. 333-391.

394. Taamalli, A.; Arráez-Román, D.; Zarrouk, M.; Valverde, J.; Segura-Carretero, A.; Fernández-Gutiérrez, A. The occurrence and bioactivity of polyphenols in Tunisian olive products and by-products: A review. J. Food Sci. 2012, 77, R83-R92. [CrossRef] [PubMed]

395. Cirico, T.L.; Omaye, S.T. Additive or synergetic effects of phenolic compounds on human low density lipoprotein oxidation. Food Chem. Toxicol. 2006, 44, 510-516. [CrossRef] [PubMed]

396. Sun, A.Y.; Simonyi, A.; Sun, G.Y. The "french paradox" and beyond: Neuroprotective effects of polyphenols. Free Radic. Biol. Med. 2002, 32, 314-318. [CrossRef]

397. Brul, S.; Coote, P. Preservative agents in foods: Mode of action and microbial resistance mechanisms. Int. J.Food Microbiol. 1999, 50, 1-17. [CrossRef]

398. Ejechi, B.O.; Akpomedaye, D.E. Activity of essential oil and phenolic acid extracts of pepperfruit (Dennetia tripetala G. Barker; Anonaceae) against some food-borne microorganisms. Afr. J. Biotechnol. 2005, 4, 258-261.

399. Naczk, M.; Shahidi, F. Nutritional and Pharmacological Effects of Food Phenolics, 2004 ed.; CRC Press: Boca Raton, FL, USA, 2004. [CrossRef]

400. Bracke, M.E.; Depypere, H.T.; Boterberg, T.; van Marck, V.L.; Vennekens, K.M.; Vanluchene, E.; Nuytinck, M.; Serreyn, R.; Mareel, M.M. Influence of tangeretin on tamoxifen's therapeutic benefit in mammary cancer. J. Natl Canc Inst. 1999, 91, 354-359. [CrossRef]

401. DeJong, S.; Lanari, M.C. Extracts of olive polyphenols improve lipid stability in cooked beef and pork: Contribution of individual phenolics to the antioxidant activity of the extract. Food Chem. 2009, 116, 892-897. [CrossRef]

402. González-Larena, M.; Cilla, A.; García-Llatas, G.; Barberá, R.; Lagarda, M.J. Plant sterols and antioxidant parameters in enriched beverages: Storage stability. J. Agric. Food Chem. 2012, 60, 4725-4734. [CrossRef] [PubMed]

403. Tarko, T.; Duda-Chodak, A.; Semik, D.; Nycz, M. The use of fruit extracts for production of beverages with high antioxidative activity. Potravinarstvo 2015, 9, 280-283. [CrossRef]

404. Kranz, P.; Braun, N.; Schulze, N.; Kunz, B. Sensory quality of functional beverages: Bitterness perception and bitter masking of olive leaf extract fortified fruit smoothies. J. Food Sci. 2010, 75, S308-S311. [CrossRef] [PubMed]

405. Guillén, R.; Heredia, A.; Felizón, B.; Jiménez, A.; Montaño, A.; Fernández-Bolaños, J. Fibre fraction carbohydrates in olea europaea (gordal and manzanilla var.). Food Chem. 1992, 44, 173-178. [CrossRef]

406. Jimenez, A.; Guillen, R.; Fernandezbolanos, J.; Heredia, A. Cell-wall composition of olives. J. Food Sci. 1994, 59, 1192-1196. [CrossRef]

407. Galanakis, C.M. Olive fruit dietary fiber: Components, recovery and applications. Trends Food Sci. Technol. 2011, 22, 175-184. [CrossRef]

408. Coimbra, M.A.; Waldron, K.W.; Selvendran, R.R. Isolation and characterisation of cell wall polymers from the heavily lignified tissues of olive (Olea europaea) seed hull. Carbohydr. Polymer. 1995, 27, 285-294. [CrossRef] 
409. Laufenberg, G. Regulierung Einer Mikroorganismenflora mit Oliventresterextrakten-Nutzung des Fungiziden und Bakteriziden Potentials Natürlicher Polyphenole zur Kontrolle von Pflanzenkrankheiten. 2007. Available online: https://www.ilt.uni-bonn.de/papierkorb/upgrading/regulierung-einermikroorganismenflora-mit-oliventresterextrakten (accessed on 14 August 2017).

410. Valiente, C.; Arrigoni, E.; Esteban, R.M.; Amado, R. Chemical-composition of olive by-product and modifications through enzymatic treatments. J. Sci. Food Agric. 1995, 69, 27-32. [CrossRef]

411. Dufresne, A.; Dupeyre, D.; Paillet, M. Lignocellulosic flour-reinforced poly (hydroxybutyrate-co-valerate) composites. J. Appl. Polym. Sci. 2003, 87, 1302-1315. [CrossRef]

412. Amar, B.; Salem, K.; Hocine, D.; Chadia, I.; Juan, M.J. Study and characterization of composites materials based on polypropylene loaded with olive husk flour. J. Appl. Polym. Sci. 2011, 122, 1382-1394. [CrossRef]

413. Cardoso, S.M.; Coimbra, M.A.; Lopes da Silva, J.A. Calcium-mediated gelation of an olive pomace pectic extract. Carbohydr. Polymer. 2003, 52, 125-133. [CrossRef]

414. Galanakis, C.M.; Tornberg, E.; Gekas, V. A study of the recovery of the dietary fibres from olive mill wastewater and the gelling ability of the soluble fibre fraction. LWT Food Sci. Technol. 2010, 43, 1009-1017. [CrossRef]

415. Cardoso, S.M.; Coimbra, M.A.; da Silva, J.A.L. Temperature dependence of the formation and melting of pectin-Ca 2 + networks: A rheological study. Food Hydrocoll. 2003, 17, 801-807. [CrossRef]

416. Brozzoli, V.; Crognale, S.; Sampedro, I.; Federici, F.; D’Annibale, A.; Petruccioli, M. Assessment of olive-mill wastewater as a growth medium for lipase production by candida cylindracea in bench-top reactor. Bioresour. Technol. 2009, 100, 3395-3402. [CrossRef] [PubMed]

417. Sarris, D.; Galiotou-Panayotou, M.; Koutinas, A.A.; Komaitis, M.; Papanikolaou, S. Citric acid, biomass and cellular lipid production by yarrowia lipolytica strains cultivated on olive mill wastewater-based media. J. Chem. Technol. Biotechnol. 2011, 86, 1439-1448. [CrossRef]

418. Laconi, S.; Molle, G.; Cabiddu, A.; Pompei, R. Bioremediation of olive oil mill wastewater and production of microbial biomass. Biodegradation 2007, 18, 559-566. [CrossRef] [PubMed]

419. Aouidi, F.; Khelifi, E.; Asses, N.; Ayed, L.; Hamdi, M. Use of cheese whey to enhance geotrichum candidum biomass production in olive mill wastewater. J. Ind. Microbiol. Biotechnol. 2010, 37, 877-882. [CrossRef] [PubMed]

420. Arous, F.; Azabou, S.; Jaouani, A.; Zouari-Mechichi, H.; Nasri, M.; Mechichi, T. Biosynthesis of single-cell biomass from olive mill wastewater by newly isolated yeasts. Environ. Sci. Pollut. Res. 2016, 23, 6783-6792. [CrossRef] [PubMed]

421. Papankolaou, S.; Galiotou-Panayotou, M.; Fakas, S.; Komaitis, M.; Aggelis, G. Citric acid production by yarrowia lipolytica cultivated on olive-mill wastewater-based media. Bioresour. Technol. 2008, 99, 2419-2428. [CrossRef] [PubMed]

422. Haddadin, M.S.; Abdulrahim, S.M.; Al-Khawaldeh, G.Y.; Robinson, R.K. Solid state fermentation of waste pomace from olive processing. J. Chem. Technol. Biotechnol. 1999, 74, 613-618. [CrossRef] 